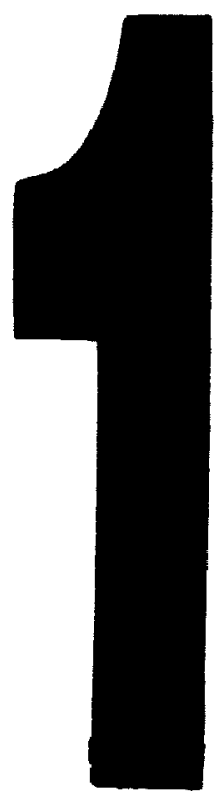

PM-1 3K" "X4" PHOTOCRAPHC IMCROCOPY TARCET

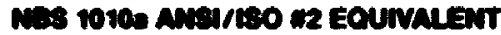

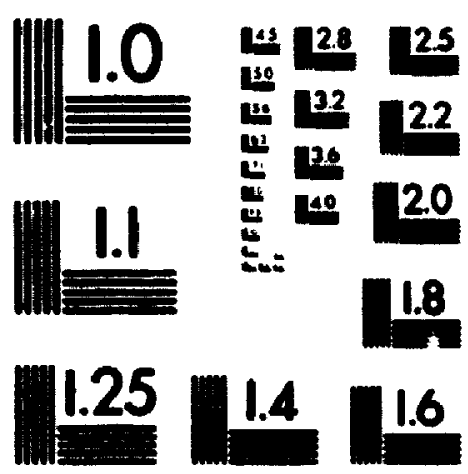

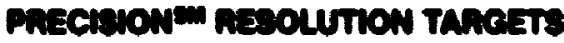


National Libray

of Canada

Acquisitions and

Biblographic Services Branch

303 wemineson sweet

Outera. Onterio

Kinowa
Bibliotheque nationale

cu Canada

Direction des acquisitions ef

des senvices bibliographiques

30s. now wimingon

Onima (Onteio)

rinoin

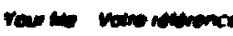

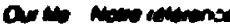

NOTICE

AVIS

The qualty of this microform is hoavily dependent upon the yuality of the original thesis submitted for microfilming. Every effort has been made to ensure the highest quality of reproduction possible.

If pages are missing, contact the university which granted the degree.

Some pages may have indistinct print especially if the original pages were typed with a poor typewriter ribbon or if the university sent us an inferior photocopy.
La qualite de cette microforme depend grandement de la qualité de la thise soumise au microfilmage. Nous wons tout fait pour assurer une qualité supérieure de reproduction.

S'il manque des pages, veuillez communiquer avec l'université qui a conféré le grade.

La qualite d'impression de certaines pages peut laisser à désirer, surtout si les pages originales ont été dactylographibes à l'aide d'un ruban use ou si liuniversitt nous a falt parvenir une photocople de qualite inferieure.

La reproduction, même partielle, de colte microforme est soumise i la Lol canadienne sur le drolt d'auteur, SRC 1970, c. C-30, of ses amendements subséquents.
Reproduction in full or in part of this microform is governed by the Canadian Copyright Act,

R.S.C. 1970, C. C-30, and subsequent amendments. 


\title{
A RENEWAL PLAN fOR CANAdIAN INTELligenCE
}

$$
\text { by }
$$

\section{PETER D. HILL}

\author{
A thesis submitted to \\ the Faculty of Graduate Studies and Research \\ in partial fulfilment of \\ the requirements for the degree of
}

Master of Arts

Department of Political Science

Carleton University

Ottawa, Ontario

March 28, 1995

copyright

1995, Peter D. Hill 
Netionel Library

of Ceneda

Acovicitions and Bibilographic Senvices Branch

305 Whelingon Streer Onimanionero Kiacin
Bibliotheque nationale du Canada

Direction des acquisitions of

des senvices bibliographiques

385. ne Welingion

Oitrwa (Onterso)

KIAONA
You tis vaturnerese

Our the Nome renerence
THE AUTHOR HAS GRANTED AN IRREVOCABLE NON-EXCLUSIVE LICENCE ALLOWING THE NATIONAL LIBRARY OF CANADA TO REPRODUCE, LOAN, DISTRIBUTE OR SELL COPIES OF HIS/HER THESIS BY ANY MEANS AND IN ANY FORM OR FORMAT, MAKING THIS THESIS AVAILABLE TO INTERESTED PERSONS.
L'AUTEUR A ACCORDE UNE LICENCE IRREVOCABLE ET NON EXCLUSIVE PERMETTANT A LA BIBLIOTHEQUE NATIONALE DU CANADA DE REPRODUIRE, PRETER, DISTRIBUER OU VENDRE DES COPIES DE SA THESE DE QUELQUE MANIERE ET SOUS QUELQUE FORME QUE CE SOIT POUR METTRE DES EXEMPLAIRES DE CETTE THESE A LA DISPOSITION DES PERSONNE INTERESSEES.

LAUTEUR CONSERVE LA PROPRIETE DU DROIT D'AUTEUR QUI PROTEGE SA THESE. NI LA THESE NI DES EXTRAITS SUBSTANTIELS DE CELLECI NE DOIVENT ETRE IMPRIMES OU AUTREMENT REPRODUITS SANS SON AUTORISATION.

ISBN $\quad 0-612-02981-6$ 
Nome

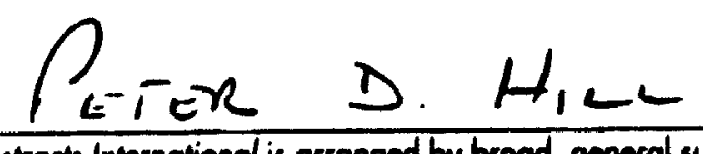

Dissentation Abstracts International is arranged by brood, general subject categories. Please select the one subject which most neorly pescribes the centent nf your dissentation. Enter the corresponding four-digit code in the spoces provided.
Politicat Science-
CENLRAC
SUECT TEM

\section{Subject Cobgories}

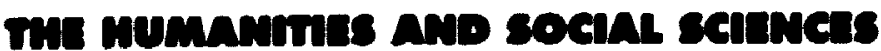

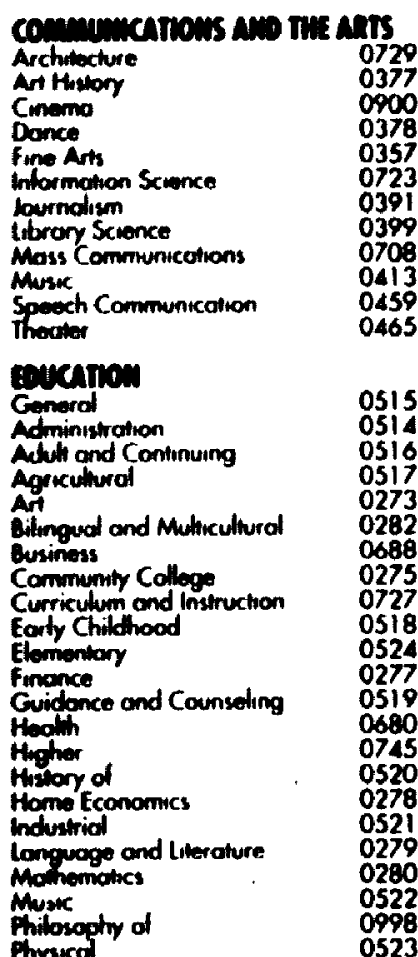

Psychology

Reoding

Religious

Sciences

Sociol Sciences

Sactology of

Spocial

Teocher Trouning

Technology

Teets and Aerourements

Vocationd

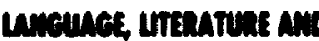

imanstics

tonquage

General

Lingurstics

Modern

Liveroture

Generd

Classical

Comporative

Modorn

African

Americon

Asion

Conodion (English)

Conadion (French)

English

Germanic

Latin Americon

Middle Eastern

Romance
Slovic and East Europeon

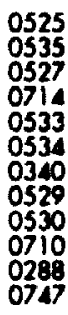

0747

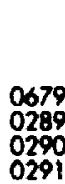

0679

0290

0401

0201

0294

0297

0298

0316

0591

0305

0352

0355

0593

0311

0312

0315

0313 mucomi, naren mo Intology

Philosophy

Raligion

Eonerol

Biblicol Sindies

Clergy

Philosophy of

Theology

sean sareats

Amerken Studius

Anthropology

Archoodogy

Culurol

Business Administrotion

Generol

Accounting

Bonking.

Monogement

Conodion Studies

Economics

Generol

Agriculinrol -Business

Finonce

History

lobor

Theory

Geogrophy

History

Generol
0318
0321
0319
0320
0322
0469

0323

0324

0326
0327

0310

0272

0770

045.

0338
0385

0385

0503

0505

0508

0508

0510

0511

0366

0351

0578

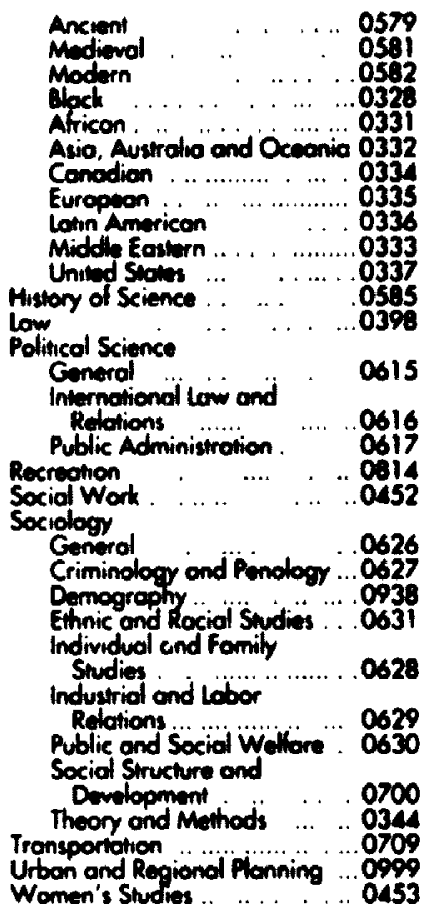

Speech Pothology $\quad 0460$

Home Economics . . . . .. 0386

mirsteal sacices

Pure Sciences

Chamistry

Generol

Agricultural

Biochemisty

Inorganic

Nucbor

Organic

Pharmaceutical

Physical

Rodiation

0566

Hoolh Sciences

Genoral
Anciulogy
Chumotheropy
Dentisiny.

Hospilal Manogoment

Human Devolopment

immunology

056

034

Nursing . . 0569

Nutrtion.

Orcupotional tholith and

Therapy.

Ophiholmotody

Potholoory

Prormokeloy . . 0419

Phormoxy .... .... . 057

Phyicel thorapy...0382

Rodiology .." 057

Mothemotics

Phrsics

Generol

Acoustics

Astronomy and

Astrophysics

Almospheric Science

Alomic

Alomic :

Elementics Pond Ekctos and

High Eneroy

Fuid ond Moumo $\ldots . . . . . . . .075$

Moleculor .. ................

Nucleor ... ........... . . \$10

Optics ........... 0752

godiotion ...................... .0758

Solid Stow ... ...................061

Statistics

Q463

Antind Salence

Applind Mechenics

0346
Engineering

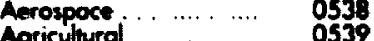

Auromotive .. . . 0540

Automotivel. . .......... 054

Chamical .. $\quad . . . . . . . . .0542$

Civil ....... Eilectroncs ond 0543

Heot and Thermodynamics .. 0348

Hydraulic .. .. ........0545

Industriol. ..........0546

Morine .... . .0547

Moveriols science . . ....... 0794

Machonical ... ..........0548

Metallurgy .... . .............0743

Mining . .... 0551

Nucleor . . . ........... 0552

Pockoging . ....................05

Petroloum …......................0765

Sonitary and Municipal .... 0554

Syymm Science ................... Of

Operotions Reworch .... ........0798

Plostics Technology ............0795

Pextiles technology ............ . . O964

Arougesr

Gemerol $\quad . \ldots . .0621$

Cenovioral .... ...

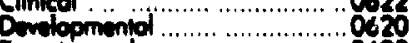

Experimentol . . ............0623

Industriol ... ..

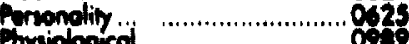

Pryioboncel ........................... Op.

Prehobidogy . .....................

Pychomminics ……................8431
General .. ........... $053 \mathbf{0 5 3}$ 
The undersigned hereby recommend to the Faculty of Graduate Studies and Research

acceptance of the thesis.

\section{A RENEWAL PLAN FOR CANADIAN INTELligenCE}

submitted by

Peter D. Hill, B.A. Hons.

in partial fulfilment of the requirements

for the degree of Master of Arts
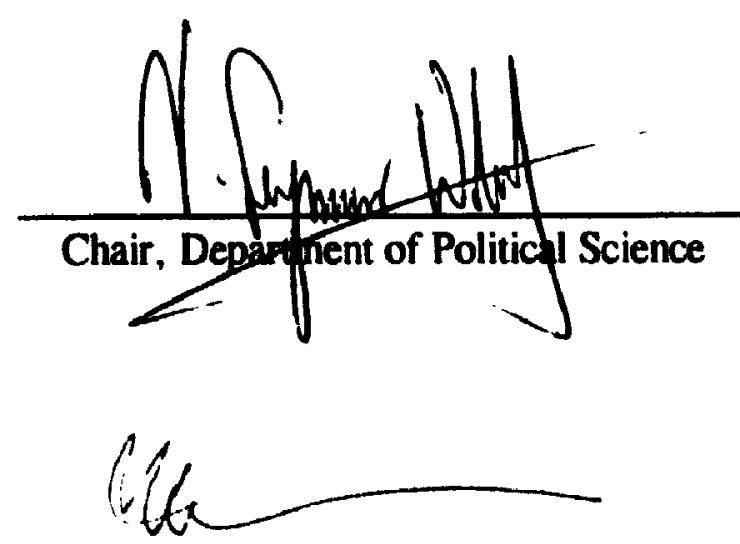

Thesis Supervisor

Carleton University

March 27, 1995 


\section{ABSTRACT}

Canada's intelligence policy and programs require a complete overhaul to be effective, accountable and affordable in the national interest. Otherwise, they risk obsolescence and growing demand for dismantlement. A "threat-ambiguous"' environment exists and is difficult to plan for. A renewal plan for Canadian intelligence confronts profound change, nationally and internationally. Order and security remain elusive after the Cold War. Globalization affects space and time by rendering borders porous, encouraging migration and continental integration, and blurring distinctions between both foreign and domestic policies and security and foreign intelligence. Sovereignty is being reshaped and the freedom and capacity of government to control events reduced. Effective, accountable intelligence activity would help maximize benefits to Canada at least cost. To this end, Canadian intelligence activity requires new statutory and strategic frameworks, skills, integrated processes and substantial intellectual and financial resources. Government's challenge is to identify core values, principles and objectives to renew intelligence programs and to decide to whom, by whom, at what level and at what cost they should be provided in the national interest. 


\section{ACKNOWLEDGEMENTS}

Mike Whittington for introducing me to intelligence matters. Acadia University`s Agar Adamson, Marshall Conley and Gabriel Fischer fur further stimulating my interest, Geoff $\mathrm{O}^{\prime}$ Brian for supporting my entering the world of intelligence. Vic Gooch for being my security intelligence policy mentor, Alex Himelfarb for strategic advice and support, and Rhonda Hill for encouragement, personal sacrifice and charts! Many thanks to everyone who commented on earlier versions of this thesis, particularly Jon Sigler and John Fraser. The views expressed in this thesis are the author's. 


\section{TABIE OF CONTENTS}

ACCEPTANCE FORM $\ldots \ldots \ldots \ldots \ldots \ldots \ldots \ldots \ldots \ldots$ ii

ABSTRACT $\ldots \ldots \ldots \ldots \ldots \ldots \ldots \ldots \ldots \ldots \ldots \ldots \ldots \ldots \ldots \ldots \ldots \ldots \ldots$

ACKNOWLEDGEMENTS $\ldots \ldots \ldots \ldots \ldots \ldots \ldots \ldots \ldots$ iv

LIST OF ILLUSTRATIONS $\ldots \ldots \ldots \ldots \ldots \ldots \ldots \ldots \ldots$ vii

CHAPTER 1. INTRODUCTION $\ldots \ldots \ldots \ldots \ldots \ldots \ldots \ldots \ldots \ldots \ldots$ I

History of Canadian Intelligence $\ldots \ldots \ldots \ldots \ldots \ldots \ldots \ldots \ldots \ldots$

What is Intelligence? . . . . . . . . . . . . . . . . . 11

A Concept of Intelligence for Canada $\ldots \ldots \ldots \ldots \ldots \ldots \ldots \ldots \ldots$

What is National Security? . . . . . . . . . . . . . . . 21

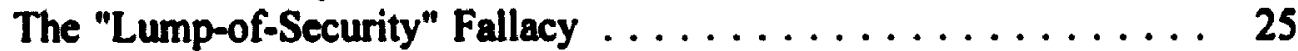

Militaristic Fallacy .................... 25

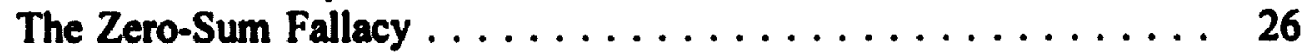

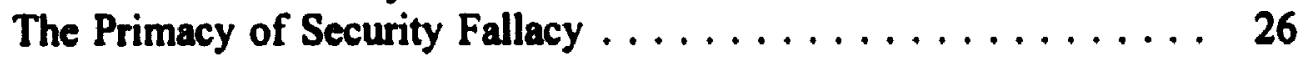

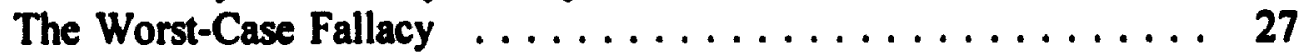

How Much Security? . . . . . . . . . . . . . . . 28

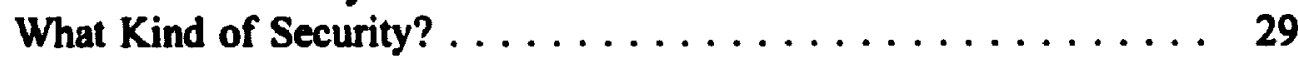

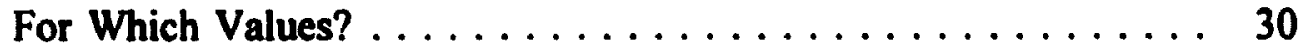

From What Kinds of Threats? $\ldots \ldots \ldots \ldots \ldots \ldots \ldots \ldots \ldots, 31$

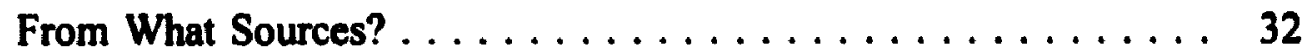

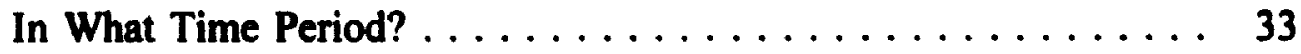

By What Means? ..................... 33

At What Cost? ...................... 34

Strategic Agenda for Canadian Intelligence Policy . . . . . . . . . 35

Principles for Redesigning the Canadian Intelligence Sector $\ldots \ldots \ldots, 41$

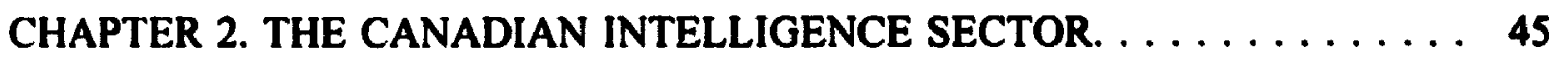

Components . . . . . . . . . . . . . . . . . . . . 46

Parliamentary Sub-Committee on National Security . . . . . . 47

Security Intelligence Review Committee . . . . . . . . . 49

Inspector General of CSIS $\ldots \ldots \ldots \ldots \ldots \ldots \ldots \ldots \ldots, 51$

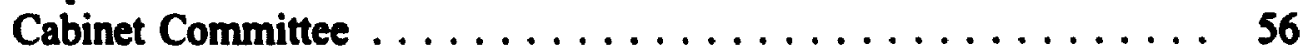

Solicitor General $\ldots \ldots \ldots \ldots \ldots \ldots \ldots \ldots \ldots \ldots \ldots \ldots$

Canadian Security Intelligence Service . . . . . . . . . 60

Royal Canadian Mounted Police ............... 64

Transport Canada . . . . . . . . . . . . . . . 65

Citizenship and Immigration Canada $\ldots \ldots \ldots \ldots \ldots \ldots \ldots 66$

Revenue Canada (Customs) . . . . . . . . . . . . . 67 
Foreign Affairs and International Trade Canada $\ldots \ldots \ldots \ldots .67$

Department of National Defence . . . . . . . . . . . . . . . . 69

Communications Security Establishment $\ldots \ldots \ldots \ldots \ldots \ldots . \ldots 70$

Joint Task Force Two . . . . . . . . . . . . . . . . 71

Privy Council Office, Security and Intelligence Secretariat . . . . 72

Department of Justice . . . . . . . . . . . . . . . . . 73

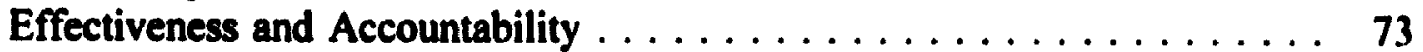

Program Review Process $\ldots \ldots \ldots \ldots \ldots \ldots \ldots \ldots \ldots \ldots \ldots, 74$

CHAPTER 3. STRATEGIC FRAMEWORK FOR CANADIAN

INTELLIGENCE $\ldots \ldots \ldots \ldots \ldots \ldots \ldots \ldots \ldots \ldots \ldots$

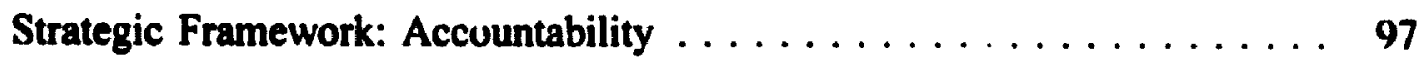

Legal Framework . . . . . . . . . . . . . . . . 103

The Role of Parliament . . . . . . . . . . . . . . 108

National Security Review Committee $\ldots \ldots \ldots \ldots \ldots \ldots \ldots 113$

Executive Accountability . . . . . . . . . . . . . . 114

Cabinet ......................... 116

Centralization and Coordination . . . . . . . . . . 119

Inspector General for National Security $\ldots \ldots \ldots \ldots \ldots \ldots 126$

Strategic Framework: Effectiveness $\ldots \ldots \ldots \ldots \ldots \ldots \ldots \ldots \ldots 127$

Partnerships . . . . . . . . . . . . . . . . 128

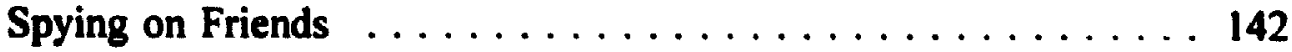

Foreign Intelligence $\ldots \ldots \ldots \ldots \ldots \ldots \ldots \ldots \ldots \ldots \ldots 147$

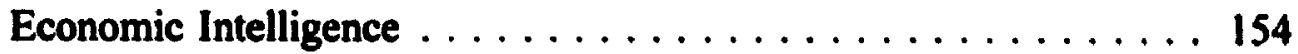

Intelligence Support to Law Enforcement . . . . . . . . . . . . 159

Strategic Intelligence for Canadian Statecraft $\ldots \ldots \ldots \ldots \ldots 163$

CHAPTER 4. CONCLUSIONS $\ldots \ldots \ldots \ldots \ldots \ldots \ldots \ldots \ldots \ldots \ldots$

SUMMARY OF RECOMMENDATIONS $\ldots \ldots \ldots \ldots \ldots \ldots \ldots \ldots \ldots$

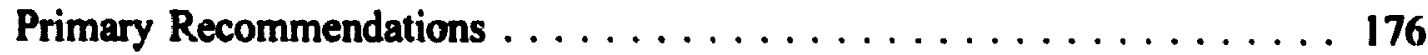

Secondary Recommendations . . . . . . . . . . . . . . . . 184

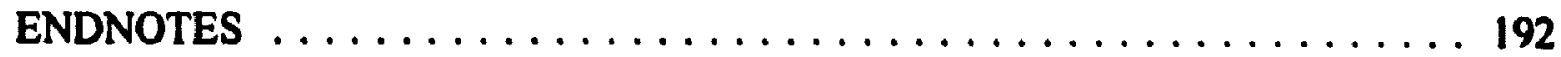

BIBLIOGRAPHY $\ldots \ldots \ldots \ldots \ldots \ldots \ldots \ldots \ldots \ldots \ldots \ldots \ldots .208$ 


\section{LIST OF ILLUSTRATIONS}

ILLUSTRATION 1. CANADIAN NATIONAL SECURITY SYSTEM

(Current) $\ldots \ldots \ldots \ldots \ldots \ldots \ldots \ldots \ldots \ldots \ldots \ldots \ldots \ldots \ldots \ldots$

ILLUSTRATION 2. CANADIAN NATIONAL SECURITY SYSTEM

(Proposed) $\ldots \ldots \ldots \ldots \ldots \ldots \ldots \ldots \ldots \ldots \ldots \ldots \ldots \ldots \ldots$

ILLUSTRATION 3. SUPPLEMENTARY INFORMATION $\ldots \ldots \ldots \ldots \ldots$ 


\section{CHAPTER 1. INTRODUCTION}

\section{Hintory of Canadian Intelligence}

The principal threat to Canada which prompted the Government to establish a permanent, peacetime intelligence capacity at the end of World War II has now all but disappeared. In the words of York University Professor Reg Whitaker. "From 1946 through most of the 1980s, Canadian intelligence policy was bound by a set of particular institutional arrangements and one overarching assumption. Everything was premised on the Cold War: the threat posed to Canada and its allies came from the hostile actions of the Union of the Soviet Socialist Republics (USSR), its Communist bloc of satellite and allied nation-states, and the international Communist movement with its local manifestations in the Canadian Communist Party together with its front organizations."

While the collapse of the Cold War did not signal the end of all threats to Canada's national security, it was a "dramatic blow to the intelligence agencies whose practices and reasons for existing were now being questioned." ${ }^{3}$ The era of bipolar superpower confrontation which threatened global nuclear warfare has been superseded by a less threatening environment. Overall, however, the environment is "more turbulent", to quote Canada's former Security and Intelligence Coordinator, Blair Seaborn. ${ }^{4}$ To survive and prosper in this environment, Canada needs an effective and accountable 
security and intelligence capacity. This instrument of statecraft should support decision makers by providing them with timely, high quality information, analysis and advice that they find useful in managing threats and opportunities in relation to Canada's vital interests.

The aftermath of the Cold War demands a thorough examination to determine what is the "national interest" and exactly what role security and intelligence organizations should have to support it. Historically in Canada, the concept of "national security" has been viewed as a subset of the "national interest." It has been primarily used in the military context. But now, Government should broaden its conception of national security. The role of intelligence must also be diversified. Perhaps paradoxically, a broader definition of national security means the intelligence mission requires sharper focus, given declining available resources. Overall, Canada's security and intelligence organizations should be smaller, leaner, flatter, better integrated and more strategic, versatile and responsive. To achieve these objectives, programs need to be either reduced or eliminated in order to reallocate resources to place priority on the real priorities. National security can no longer be equated with the Cold War image as being the sole preserve of security and intelligence organizations. A broadened concept increases the importance of partnerships in ensuring an acceptable level of national security. Kesponsibility for national security requires a new balance between centralization and de-centralization of roles and responsibilities. National security must be a shared responsibility among federal departments and agencies, levels of 
government, both domestic and foreign. and non-governmental institutions, as well as the Canadian public.

The existing framework for Canadian intelligence is the product of almost lifty Cold War-dominated years of ad hoc evolution. The framework has demonstrated a certain responsiveness to changes to the probablity and magnitude of threats. This fact is demonstrated by the disbandment of the Canadian Security Intelligence Service's (CSIS) counter subversion program in $1988^{5}$ and the growth of its counter terrorism capability over the years. But, the current government-wide framework for security and intelligence activity appears to be insufficiently responsive to the new environment to shift in the strategic direction demanded by accelerated change. Carleton University Professor Simon Dalby has noted that:

...the cause of some of the threats, that state agencies should supposedly be monitoring, may be present in precisely the contemporary political order of modernity that security and intelligence agencies have traditionally taken as their mandate to protect. $^{6}$

What is a threat to national security? When does the right to advocacy, protest and dissent, for example, become a legitimate national security concern requiring covert intervention by government agencies? At what point does free inarket, international commercial competition become foreign state sponsored economic espionage? $A$ range of perplexing challenges face Government and intelligence organizations as they enter the 21 st century. One key to success is effective leadership. 
During recent years, the Coordinator, Security and Intelligence of the Privy Council Office (PCO) has been responsible for supporting the Prime Minister and ensuring overall coordination, monitoring and direction of policies and programs implemented by the security and intelligence sector at the bureaucratic level. ${ }^{7}$ When the Coordinator position was established in 1987, however, responsibility for security was added to the role only at the last minute, almost as an after thought. This fact suggests that security and foreign intelligence have not been well integrated in Canada. Non-integration has been the deliberate policy. Integration in the security and foreign intelligence sector occurred almost exclusively at the apex of the system, represented by the Deputy Minister level Interdepartmental Committee on Security and Intelligence (ICSI) and, ultimately, the former Cabinet Committee on Security and Intelligence (CCSI). Non-integration has reflected the fact that consumption of intelligence product by the Government of Canada is minimal in comparison with other nationstates. Nevertheless, Canada's intelligence capability has been a useful instrument for the Government of Canada to task in support of multilateral cooperation. Perhaps Canadian intelligence has been most useful simply when it didn't cause political embarrassment. Alternativèly, intelligence has served government bureaucrats in a range of areas, including screening prospective immigrants or citizens, deporting illegal migrants who are criminals or security risks and supporting law enforcement agencies. 
The position of intelligence within the governmental structure is a useful indicator of the roles and expectations that Government has for its intelligence capacity. In Canada, Government's expectations of security and intelligence have heen minimal. This thesis suggests that Government should change its thinking and develop and use its security and intelligence capacity as an integral component of Canadian statecraft. To this end, the Government should now publicly dismantle the old policy and structure and replace it with a new vision, mission and integrated system. Integration of intelligence objectives, processes and organizations within the intelligence sector (or intelligence community') itself, as well as with government's broader agenda is essential to the continuing relevance, effectiveness, accountability and sustainability of the program in the national interest.

Canadian intelligence officials have spoken of "intelligence" as if they meant both security and foreign intelligence. In fact, they really have had two separate categories in mind. The first is security intelligence concerning "threats" based on the Canadian Security Intelligence Service model. The second is foreign intelligence which, in the Canadian experience, has been equated with "signals intelligence" provided by the Communications Security Establishment (CSE). This split meant that the Coordinator for Security and Intelligence lacked sufficient authority to allocate resources at both the macro and micro levels across the intelligence sector as a whole. As a result, the Coordinator never had the freedom or the capacity to effectively lead Canadian intelligence and establish a vision, mission and strategic priorities for Canada's 
intelligence sector. Control and accountability have been decentralized throughout the intelligence sector and, partly as a result, it is not clear that "the Privy Council Office's role in security and intelligence matters is exercised to its fullest capacity." 10

The concept of a decentralized management system for intelligence may have been appropriate for Canadian interests when resources increased and the principal targets for collection, analysis and advice were clear. In past years, there may have been sound reasons not to consolidate parts of the security and foreign intelligence function. Decentralization was seen as a defence against penetration by hostile intelligence agencies. Knowledge was compartmentalized to contain damage caused by actual "moles." Decentralization was a way to manage fear of the contagion effect that foreign intelligence operational methods could have on the modus operandi of a security intelligence service founded on respect for the rule of law."

Decentralization is less compelling given a diminished strategic threat and government's increasing emphasis, in response to public pressure, on mechanisms for redress and accountability. Integration and centralized management of certain aspects of the intelligence process, economies of scale, effective ministerial and executive accountability are paran cunt in a period of fiscal restraint where the priorities of Canada's national security interests are less clear. But the need for integration is not universal. The quality of intelligence analysis, for example, should be improved by 
other means, such as finding new ways to recruit top quality analysts and to integrate the work of analysts with government's broader policy process and with nongovernment institutions.

On balance, Canada s national security interests have been served less than satisfactorily by the intelligence sector over the several decades of its existence. It has not, for various reasons, performed as well as it might have. Part of the problem has been a lack of political leadership. In addition, the apparatus for collecting, analyzing, monitoring, countering, reporting and advising the Government about terrorist and hostile foreign intelligence activity grew from the postwar period to the present with inadequate thought of matching "what we could do with what we had to do." ${ }^{n 12}$ The deliberate separation of criminal, security, foreign and military intelligence led to unnecessary duplication among intelligence organizations. Policy development for CSIS activity, for example, was conducted by numerous players without effective coordination. The process included the Solicitor General, the Deputy Solicitor General, CSIS, the Solicitor General Secretariat, the Security Intelligence Review Committee (SIRC), the Inspector General of CSIS, the Security and Intelligence Secretariat of the Privy Council Office, among others. Intelligence gathering and analysis was conducted across the sector without effective cooperation or proper regard to organizational mandate. Efforts to institute a centralized assessments function at the Privy Council Office produced mixed results. 
In general, the intelligence priorities setting process and intelligence products remained too isolated from the governmental process it was created to serve and protect. By comparison with other western liberal democracies, the demand for intelligence by Canadian decision-makers was lower. Blair Seaborn noted that making good use of intelligence does not come readily to all decision makers; it is a learned practice and one which must be constantly encouraged. ${ }^{13}$ Was Canada's intelligence product inferior? Such a sweeping generalization could be unfair, although weaknesses and "failed starts"14 have been noted. Published examples suggest that, from time to time, government placed high value on "raw" intelligence (as opposed to intelligence resulting from analysis) collected by CSE. In 1981, CSE is alleged to have inadvertently intercepted a conversation between the American Ambassador to Canada and an American official at the embassy in Canarla about an upcoming wheat deal between the United States and China in which Canada was a competitor. Intelligence from the CSE intercept enabled the Canadian Wheat Board, rather than the United States Administration, to sign a long-term agreement with China worth approximately \$2.5 billion at current prices. ${ }^{15}$

Even to the casual Canadian observer the lack of concern over questions of national security is readily apparent. It is probably not that the concept is misunderstood, nor that Canadians are less patriotic than others. Canadians seem to feel "secure." As the debate on the post-Cold War roles of intelligence organizations evolved, distinctions in political cultures were highlighted. In Washington, the debate has been "lively and 
largely public."17 In Ottawa, it has been "muted and largely private"." The politics of intelligence changed in Britain when Prime Minister Major established a statutory basis and Parliamentary review for the major elements of the British intelligence community, ${ }^{19}$ including the Security Service, the Secret Intelligence Service and the Government Communications Headquarters. By contrast, Canadians and their politicians have focused on other areas of government, such as foreign, defence and immigration policies. Intelligence and national security policies have not received a comparable level of attention, except in cases of intelligence "failure." Over the years since the Royal Commission of Inquiry into the alleged activities of the RCMP's Security Service, several intelligence f::lures sparked debate about the effectiveness and accountability of Canadian intelligence. The most prominent examples include the 1985 bombing of Air India flight 177, the Atwal warrant affair in 1987 which led to the resignation of the first Director of CSIS, CSIS's alleged wrongdoing concerning the white supremacist Heritage Front (disavowed in late 1994 by the Security Intelligence Review Committee ${ }^{20}$ and a current controversy about the Communications Security Establishment's alleged non-accountable spying on allied nation-states and prominent Canadian public figures from the province of Quebec..1

The security and intelligence environment in Canada has at least two key features. First, it has a political culture that exhibits no real enthusiasm for security and intelligence matters. Ministers of the Crown and citizens, too, have largely ignored national security issues and institutions in Canada. Second, security or intelligence 
disasters occur periodically and they shock the political level which tends to respond by demanding expiditious measures to correct the immediate problem. Real political interest is generated in short bursts, usually around intelligence failure. The aim is to quickly fix the specific problem. Although the event may be symptomatic of systemic weakness or breakdown, attention has rarely been focussed on the system. Even the decision to create CSIS occurred only during the dying days of the Trudeau era following recommendations by two Royal Commissions of Inquiry (Mackenzie in 1969 and McDonald in 1981) to 'civilianize' the security intelligence function.

Disinterest or fear of "creating a security and intelligence monolith in a democratic state"22 contributed to the fragmentation of Canada's intelligence sector. In turn, fragmentation contributed to systemic dysfunction, in terms of both effectiveness and accountability. To address the foregoing problems, a new integrative strategy is required to improve Canada's intelligence capacity. Otherwise it will fail to support Canada's decision makers and Canadian statecraft during a critical period of societal transition and globalization.

What should be done to "reinvent" the Canadian intelligence sector? The post-Cold War era demands an increasingly flexible and responsive intelligence capability. More than ever intelligence services must anticipate, understand and lever maximum benefit from declining available resources in the national interest. ${ }^{23}$ The passing of the strategic communist threat should yield a peace dividend. In the final analysis, Canada 
needs an intelligence capability. It must be rebuilt based on public input. It must be efficient, effective, accountable, affordable and respectful of the rule of law and the rights of the individual. The new system will have no credibility, nationally or internationally, unless it embodies the Canadian values of justice, tolerance and compassion, which are a hallmark of our society. 24

\section{What is Intellirence?}

Intelligence is an elusive concept. The answer to the question is not obvious, and the implications are more than merely semantic. Throughout the post-World War II period, the answer in Canada was generally intuitive or, at least, implicit rather than explicit. The assumptions were based on parameters shaped by a bipolar international system. In the multipolar system of the post Cold War period, a nation-state's intelligence requirements depend on a variety of factors, including its political, economic and military aspirations, concerns or activities, its geographic location and the extent of its multilateral activity. National security requirements need not be met exclusively through secret or covertly acquired information. Much of the collection effort should involve 'open' or 'overt' sources and be conducted by non-intelligence organizations. The extent to which a nation-state collects intelligence through its own resources will depend on its financial resources, its ethics, its international posture and the extent to which it believes it can rely on its 'allies' .25 
Any effort by Canada to renew the intelligence sector should include full consideration of the meaning of the word 'intelligence.' Intelligence scholars and practitioners, such as Dr. Kenneth E. de Graffenreid, have noted that any discussion about intelligence "is somewhat confused by the fact that when we say the word 'intelligence', almost everybody is talking about something slightly different. ${ }^{\text {m26 }}$ Lack of clarity on the concept could cause the Government of Canada and its intelligence organizations, faced with changing priorities and declining resources, to lose sight of proper tasks, leading to unforeseen crises. ${ }^{27}$ De Graffenreid stated that:

No serious discussion, let alone decision, about the place, organization, relationship, requirement, size, budget or almost anything else about intelligence can be usefully considered until we define what the missions are that we expect our intelligence organizations to perform. ${ }^{23}$

If the concept of intelligence ever was a "simple and self evident thing"29 it has, over time, become ambiguous. The word itself is used to describe diverse phenomena. Intelligence means a kind of knowledge or specialised type of information. It describes a type of organization which produces this knowledge or specialised information. And, it refers to the activity or processes carried out by the intelligence organization. ${ }^{30}$ In the minds of many analysts, intelligence is associated with a special kind of knowledge or information. 
"Security intelligence" applied to threats originating at home or abroad against the core values and the basic integrity of the nation-state. It concerned threats posed by terrorism, espionage, sabotage, subversion and, occasionally, beliefs. "Foreign intelligence" related to the activities, capabilities and intentions of foreign nation-states. organizations, groups or individuals in support of the defence or foreign affairs of a nation-state. "Military intelligence" concerned tactical matters such as the disposition of the enemy's troops and equipment in the field and strategic matters, such as a nation-s:ate's long term capabilities, overall armed strength and the capacity to maintain it. "Signals intelligence" referred to a technique which included various kinds of intelligence derived from radar, electromagnetic, and electronic emissions collected by technical means. "Criminal intelligence" applied to information in the law enforcement context which police agencies required to investigate, counter and apprehend those engaged in organized crime, smuggling, drug trafficking, extortion, terrorism or other illegal conduct that arose from activities which constituted a national security threat. ${ }^{31}$ "Commercial or industrial intelligence" related to the capabilities, activities or intentions of one's commercial rivals and competitors. ${ }^{32}$ It often extended to include acquisition of confidential or proprietary information about strategies, bid information, manufacturing processes, finances or markets. "Economic intelligence," to paraphrase Schumpeter, was what economists did in and for intelligence agencies." It was economic data collection and analysis in support of a nation-state's strategy and tactics. It excluded the endeavour of private individuals and organizations to obtain confidential and privileged information about technology, business connections, prices 
and financial plans of rivals or clients. It also excluded assessments of the current or future economy by private individuals and firms or government offices outside the intelligence community, although it made use of such reports. ${ }^{34}$

Recent additions to the list are "open source intelligence" and "grey intelligence." Both of these kinds of intelligence have emerged as powerful tools for strategic understanding. Technological and information revolutions made available to analysts through computer links enormous amounts of data from libraries, think tanks, media, and so on. An estimated $80 \%$ of the input to the assessed intelligence produced by the United States Central Intelligence Agency (CIA) comes from open sources. "Grey intelligence" is related to grey information which, in very simple terms is unindexed materials. ${ }^{37}$ More specifically, grey literature is:

...a term of European origin which is generally taken to include scientific and technical literature which is not published in journals or in commerciallyavailable books and monographs. ...technical reports, i.e., documents which are generated as a result of R\&D and which are intended for a very limited distribution. ${ }^{32}$

Grey information is frequently one part of the total information picture which becomes part of the intelligence product following collection and analysis. Sources of grey intelligence are photocopied documents, rumours in business circles, discussions with well-informed specialists, preprints of scientific articles, and project proposals submitted to research-funding organizations. The product, grey intelligence, provides a picture of a "technological landscape ${ }^{n 39}$ which is used to competitive advantage. 
Grey intelligence sheds light on recent technological research by revealing linkages among actors and relationships among companies, research organizations and government agencies or departments.

Notwithstanding this lengthy (and only partial) list of definitions, essentially there are two basic ways to define intelligence. One approach takes a broad interpretation in which intelligence is all information necessary for decision makers. By contrast, a narrower understanding limits intelligence to a specialized type of information that is secret in nature, often intentionally withheld by both allies and enemies, and vital in supporting statecraft and related decision-making. ${ }^{40}$ The debate on the definition of intelligence is ongoing. At a recent Canadian Association for Security and Intelligence Studies (CASIS) conference in Ottawa, American and Canadian participants seemed to favour the broader interpretation and the British the narrower." These views may reflect the practical perspectives of these nation-state's intelligence organizations, respectively.

The broad interpretation was given theoretical expression by Sherman Kent's influential book of 1949 entitled Strategic Intelligence for American World Policy. ${ }^{42}$ In sum, Kent's view is that strategic intelligence is all information necessary for conducting foreign policy. It is "the knowledge upon which our nation's foreign relations, in war and peace, must rest. ${ }^{\text {nal }}$ Other advocates of the broad definition include Jeffrey T. Richelson who has defined intelligence as "the product resulting 
from the collection, evaluation, analysis, integration and interpretation of all available information which concerns one or more aspects of toreign nations or of areas of operation which is immediately or potentially significant for planning." ${ }^{\text {t4 }}$ Constantine FitzGibbon and Thomas F. Troy define intelligence broadly and simply as "knowledge of the enemy. ${ }^{\text {mas }}$ The term "enemy", of course, encompasses diverse sources of threats, including certain activities of allied or friendly nation-states.

By contrast, the narrow definition of intelligence has two key components which help explain what intelligence is, and what it is not. First, the notion of secrecy differentiates intelligence from just any publicly available information. Second, the notion that intelligence is specialized information sets parameters. Information which provides advantage or at least provokes decision makers to ask the right questions ${ }^{46}$ in the protection or pursuit of national interests connotes a special type of information. American intelligence scholars and practitioners Dr. Kenneth E. de Graffenreid, Dr. Abram Shulsky, Dr. Walter Laqueur and Dr. Ernes May, unlike many of their American colleagues, assert that intelligence is also a limited function. In their view, intelligence services should not properly be the ultimate analysts of national security. ${ }^{47}$ The broader job is beyond the appropriate scope and expertise of intelligence because too much information is necessary and available for one to be able to centralize it and organize it in one place. In this respect, the challenge for government is to focus the 
purpose of intelligence services and to find alternate ways to reach out, integrate analysts into the broader analytical 'community' and obtain information, analysis and expert advice that exists dispersed throughout society.

Perhaps the clearest case of the latter challenge noted above involves economic intelligence. It makes little sense to use the current model of intelligence organization that tasks some government department or agency to collect and analyze intelligence to produce the economic information Government or the bureaucracy needs. This is not to say Government does not need a Department of Finance. Rather, the mandate of an intelligence organization must be limited and carefully defined. Economic information needed by Government or the bureaucracy is produced by Finance, Treasury Board, Wall Street and so on. Intelligence cannot hope to duplicate it, nor should it try. Law enforcement data presents similar problems. To deal with international narcctics trafficking and organized crime, intelligence must explain links between foreign suppliers of narcotics and domestic consumers. Much of this data will be developed by law enforcement agencies in the performance of their duties, and much of it will deal with domestic activities, including Canadians. The full analysis of the narcotics problem, for example, should not be an intelligence issue, although some specialized strategic intelligence information may be useful in managing the problem. ${ }^{49}$

With the end of the Cold War and increasing globalization, distinctions among categories of intelligence are being blurred at the same time as the potential subject 
matter for various categories of intelligence has broadened. ${ }^{\text {so }}$ For example, the intensity of regional separatist revolts in Punjab, in India's northeastern states or the politics in India's Tamil Nadu state,where the most ruthless of Sri Lanka's Tamil rebels now exert de facto control, or the activity of Muslim extremists in the Middle East and parts of Africa such as Algeria, are all of concern to foreign intelligence because of the potential to cause inter-state or intra-state instability. But communal political violence and strife is also of concern to security intelligence when tension and violence is transplanted by migrants (i.e., immigrants, refugees, illegal migrants, visitors, etc.) from those nation-states and vaged in Canada. Russian organized crime is of concern to foreign intelligence to the extent that it may destabilize regimes in nation-states where Canada has social, economic or political interests. It is also of legitimate concern to criminal intelligence where crime networks enter Canada, and to security intelligence if Russian intelligence organizations monitor, or become entangled in, such activity in Canada.

As Canada's former Security and Intelligence Coordinator, Blair Seaborn, noted:

The essential lesson is that intelligence categories are no longer, if they ever were, water tight compartments, and that much intelligence produced for one client is also of interest to others."

This lesson is instructive for the renewal of Canadian intelligence. Greater overlap and shared jurisdiction corm, dicate planning and prograun delivery. Increasing complexity compels new partnerships, greater intelligence exchange, and better 
coordination and cooperation within the intelligence sector and beyond. In sum, a more integrated intelligence capacity is needed to meet government's requirements in the post Cold War era.

\section{A Concept of Intellirence for Caneda}

This thesis supports the view that intelligence is a limited product and function. $A$ limited concept should pre-empt the notion that intelligence, either as discipline or organization, is or should be "all-knowing." It would be dangerous to cling to outmoded fiction, represented by the former-Soviet $\mathrm{KGB}$, which models intelligence as a single centre for truth, information gathering and analysis, on which government would place primary reliance in determining the whole range of its national security policies. No organization with such a broad mandate is likely to be efficient or effective. Christopher Andrew, the British historian and intelligence expert, has noted that western analysts overrated the KGB and overlooked its "shear bureaucratic inefficiency." ${ }^{\text {s2 }}$ The Israeli intelligence service MOSSAD, on the other hand, is an effective organization, in part, because its objectives are very targeted and focused..$^{33}$ In short, an all-encompassing vision for intelligence should be "recognized for the utopia which it is. "

To the extent that intelligence is a limited function, it must also be versatile and adroit in response to emerging problems and opportunities. Otherwise, it will fail to know 
and to act upon what is relevant before it is too late. Knowing "the other" who is likely to be or become your enemy or counter-player in one life situation or another has seen the primary intelligence requirement for millennia. ${ }^{55}$ Past and present records demonstrate that responses to the challenge of evaluating the human environment, defining vital national security concerns, and setting directions for security and intelligence organizations have been greatly varied. Responses have been "in each case faithful reflections of culture-specific mental dispositions, moral values and political systems. ".56

The concept of intelligence for Canada should be a specialized category of primarily secret information which is relevant to the government's formulation and implementation of policy to protect and pursue its vital national interests. Open sourced information will inevitably be useful and necessary in the formulation of intelligence assessments. To the extent that open sourced information is collected by an intelligence organization there is a corresponding need to focus that activity. Intelligence services must not be, or act as, the ultimate analysis arm of government on all matters. The risk of falling into that trap, however, appears to increase with the level of effort expended to collect and analyze open information. National security requirements must focus all collection and analysis activity. Although protection against the "adversary", for example, must be broadly conceived the specific identity of the adversary must be specified as part of an intelligence requirement. For example, an intelligence task may accompany the government's negotiation of an 
agreement with a friendly or allied government since each side is presumably competing to maximize the benefits the agreement will provide, at least in part at the expense of the other. ${ }^{37}$

In sum, the recommended concept of intelligence for Canada includes many categories of intelligence which have increasingly overlapping uses. Criminal intelligence, security or counter intelligence, foreign or positive intelligence, tactical or operational intelligence, economic intelligence, scientific intelligence, signals intelligence and military intelligences could be better integrated or fused to provide decision-makers with useful strategic intelligence. In other instances, decision makers will value raw, 'unfiltered' intelligence.

\section{What is National Security?}

A nation-state's national security policy should be grounded in the broader context of government's economic, foreign, defence, social and immigration objectives. In the past, an "imprecise" definition for national security was tolerable because it essentially focussed on protection from the Communist threat. Now, clearer guidance is needed for national security and intelligence organizations. The definition of national security should be broad but intelligence organizations should not be solely responsible for all 
national security matters. Therefore, the definition should serve as a 'platform' for security and intelligence partnerships, intergovernmental, interdepartmental, with the non-government sector and the Canadian public.

A starting point for the development of a new Canadian national security policy should be, as recommended by Ted Finn, CSIS' first Director, key "observations and assumptions about the future international power configuration and Canada's position within it." 59 The 1990 s demand a redefinition of what constitutes national security to renew the intelligence in accordance with changes in the environment. In testimony before the United States Senate Foreign Relations Committee on April 5, 1989, George Kennan noted the major reason why a new definition is needed:

Whatever reasons there may once have been for regarding the Soviet Union primarily as a possible, if not probable, military opponent, the time for that sort of thing has clearly passed. ${ }^{60}$

Closer to home, in 1994 the Special Joint Committee Reviewing Canadian Foreign Policy stated it is "convinced of the need to adopt a broader concept of security, creompassing both military and non-military factors". 61 Furthermore, the Committee recommended changes to present Cabinet and Parliamentary committee structures "to ensure that the various elements of security are addressed in an integrated manner. ${ }^{162}$

Perhaps the greatest threat to our national security is the danger that we will not change our thinking to coincide with all the changes in the world. Leadership will be 
key to the success of change management in the intelligence sector. Leadership for the social, economic and political environment of the 21 st century will depend upon a different set of assets than were required previously. Military strength will be relatively less important in determining power and influence in the world, and economic and social strength will become far more crucial. ${ }^{63}$ The sudden end in 1989 of the Cold War of East-West international bipolarity, and the monolithic threat to the West from Soviet sponsored international communism, sometimes real and sometimes perceived, altered the course of history. Demographic, economic, environmental and societal stresses are increasingly globalized, and they are challenging once sacred boundaries of national sovereignty, previously rendered porous by the information and communication revolutions and the instantaneous global movement of capital.

Leadership requires renewed instruments of statecraft to understand and derive benefit from the environment.

Perhaps paradoxically, five years after the end of the Cold War, Canada is more actively engaged in military terms abroad than at any time in the past forty years. ${ }^{\text {th }}$ The world continues to be divided. Conflict is prevalent and the once sharp dividing line between foreign and domestic policy is blurred, forcing governments to grapple in international fora with issues that were contentious enough in the domestic arena. ${ }^{65}$ Security conscious governments in all ages and places have accepted these persistent complexities as standing challenges in their conduct of foreign and domestic affairs by collecting, processing, and institutionalizing their own political intelligence. ${ }^{\text {to }}$ Canada 
faces strategic choices and trade-offs in transforming its intelligence capacity. These choices represent opportunities to develop key instruments for informing Canadian statecraft.

Not everything has changed as a result of the end of the Cold War, although there are significant new challenges and opportunities. A nation-state can aspire to have more or less "security" and the development of an appropriate formula will require that social, political and fiscal trade-offs be made. Most scholars and practitioners define national security in terms of some combination of external and internal threats to the core values of the nation-state. In Canada, there is little agreement regarding which threats against Canada exist. There is little agreement as to the likelihood or magnitude of specific threats to Canadian interests. There is also little agreement on the kind of magnitude of threats that would be tolerable, if they could be adequately assessed. In addition, there is no consensus on which core values are involved. ${ }^{67}$ Therefore, scrutinizing the political formula of "national security" is an integral component of the transformation of Canadian intelligence. The term "national security", like "intelligence", is ambiguous. The term may not have any precise meaning at all. It may be confused with related terms, such as "national interest." While appearing to offer guidance as a basis for broad consensus the term may be permitting everyone to label whatever policy is favoured with an "attractive and possibly deceptive name. ${ }^{\text {"68 }}$ 
Two ways to clarify a concept are. first, to discuss how not to think about it and. second, to ask the right questions about it. In this regard, the work of David Baldwin and Helen Milner is relevant because they have articulated common fallacies in thinking about national security and basic questions decision makers must address in making decisions on national security issues. ${ }^{69}$ These fallacies and questions are summarized and assessed below. ${ }^{70}$

The "Lump-of-Security" Fallacy

Intelligence expenditures are often discussed in terms of the levels "required" in order to "achieve" national security. Such discussions treat security as something absolute, or in other words, something a nation-s, de either has or lacks. The lump-of-security fallacy denies that security is a matter of degree. In fact, security is a value of which a nation-state can have more or less and which it can aspire to have in greater or lesser measure.

\section{Militaristic Fallacy}

The militaristic fallacy refers to the overemphasis on military aspects of national security. The danger lies in becoming so preoccupied with military threats to national security that one neglects other kinds of threats. Similarly, although military statecraft is sometimes useful in pursuing nation-states' security goals, it is not the only means 
and not always the best method by which such goals may be pursued. Diplomacy, information exchange, negotiating agreements, neutrality, as well as economic statecraft are all potentially useful means for achieving desired levels of national security.

\section{The Zero-Sum Fallacy}

The zero-sum fallacy is the assumption of a fixed amount of security so that more for one nation-state necessarily means less for another. It is sometimes true that one nation-state's attempts to strengthen its security may weaken the security of other nation-states. This is known as the 'security dilemma.' Although awareness of the possibility of security dilemmas is desirable, it is a mistake to assume that everything a nation-state does to enhance its security inevitably lessens the security of other nationstates, or actually results in enhanced security for the nation-state concerned. In general, a nation-state that tries to enhance its security through positive sanctions, accommodation and tension reduction measures is less likely to find itself in a security dilemma.

\section{The Primacy of Security Fallacy}

The undeniable fact that security is one of the fundamental goals of the nation-stale does not mean that everything done to enhance national security is necessarily moral 
or expedient. Although security is always one of the core values of a nation-state, it is never the only one. This fact is reflected in the need to balance effectiveness with accountability. Consequently, decision makers must compare the needs associated with various values other than security with security needs. At some point, sacrifices of either economic welfare or individual rights and freedoms in order to acquire an additional increment of national security will become immoral, inexpedient, or boih. Identification of the social costs of intelligence activity must entail an assessment of the proportionality of the means of intelligence in relation to the ends. It is prudent to treat national security as an important value, but it is fallacious to infer from this that national security should always be the overriding consideration.

\section{The Worat-Case Fallacy}

This fallacy is the dictate that national security policy should always be designed for the worst situation one can either tolerate or imagine. Such a mindset is key to developing and implementing effective measures to manage threats or, in other words, undertake risk management practices. But the government has an obligation to manage risks on behalf of Canadians only to the extent that the costs justify the benefits in the national interest. So, although worst case scenarios are superficially appealing and have been used to argue for "unlimited" amounts of national security spending, there are at least two reasons why preparing for the worst is not necessarily wise policy. First, resources are limited, so no nation-state can prepare for every contingency. 
Taken to its logical and ludicrous extreme, such a view would lead policy makers to view all threats as national security threats. The second reason is that such efforts may be interpreted by other states as a threat to their security, causing them to take countermeasures that tend to offset or nullify the intended security gains in a never ending spiral of increasing insecurity.

These five fallacies are not the only mistakes one can make in thinking about national security, but avoiding them at least helps one to ask the right questions about national security policy. In developing national security policy, any policy maker must also address eight basic questions: How much security, of what kind, for which values, from what kinds of threats, emanating from what sources, in what time period, and at what cost? The answers will differ from nation-state to nation-state, but the basic questions are the same for all.

\title{
How Much Security?
}

\begin{abstract}
Absolute security or zero risk is unattainable. Governments regulate only some, not all, of the threat or risk that fills the world." Consequently, all nation-states and all individuals must learn to live with a certain amount of insecurity. Most of us understand this intuitively. The determinants of a nation-state's desire for security are difficult to identify. It is at least tacitly understood that the Canadian experience with security problems has been somewhat unique. The national security of Canada, at
\end{abstract}


least in the traditional sense, has been granted, on balance, relatively free of charge by virtue of its geographical position and proximity to a friendly superpower nation-state, the United States. Canada is practically unrivalled in terms of the length of time that it has been able to prosper and develop while devoting relatively so little attention and resources to protecting and pursuing national security. It is important for policy makers to recognize that security is a matter of degree and that nation-states differ in their toleration of insecurity or risks.

\section{What Kind of Security?}

National security has both objective and subjective dimensions. In an objective sense, security is measured by the absence of threats to core values, in a subjective sense, it is measured by the absence of fear that such values will be damaged or lost. The objective and subjective dimensions of security do not necessarily coincide. A nationstate may be objectively threatened but subjectively complacent as may well be the case if environmental modelling for ozone depletion is accurate. By contrast, a nationstate may be objectively secure and subjectively fearful. Russian intelligence activity may have declined significantly since the end of the Cold War, but the popular history of KGB activity lingers in the public's mind exaggerating fears of the threat posed by the KGB's successor, the Russian Foreign Intelligence Service (SVR). Policy makers may choose to emphasize one dimension or the other in a given situation, but they should not completely disregard either. 


\section{For Which Values?}

The declaration that an issue is a matter of national security usually connotes that something important is at stake. National security policy, then, is not aimed at protecting all of a nation-state's values, but rather its core values. It does not attempt to protect all of the values associated with the "national interest" which, conceptually at least, is broader than "national security interests." Policy makers must decide which values to treat as core. One of the most important steps in formulating national security policy is making the decision about the range of values to be protected.

Most nation-states treat political sovereignty and territorial integrity as core values, but rarely do they confine themselves to such a minimum list. Although economic aspects of national security have always been important, they are likely to be even more so in the remainder of the 1990s and beyond. So, is economic welfare to be included? If so, do all threats to economic welfare or only large ones involve national security? Does national security policy include protection of foreign investments? Access to foreign markets? The essential points are, first, policy makers have a choice as to the range of values for which to seek protection. Secondly, the wider the range of values included, the greater the security and intelligence "needs" of the nation-state are likely to be. Thirdly, national security policy requires strategic trade-offs between such values as individual rights and freedoms and the public interest. This fact calls 
attention to an aspect of national security policy that is often overlooked - that is, a nation-state can change the level of its national security by compressing or expanding the range of core values.

\section{From What Kinds of Threats?}

To ask "from what kinds of threats" is also to consider "for what kinds of opportunities." In general, threats to Canada's security against which protection is needed today and during the next four years fall into three basic categories: activities of foreign intelligence agencies, politically motivated terrorism and international criminal activity. The opportunities will be related to a broad range of issues related to the government's foreign, trade, economic, defence and social objectives.

"Threat" and "opportunity" are interdependent concepts related to the notion of national security. This abstraction reflects the direct connection between security intelligence and foreign intelligence. Threats to national security take many forms. If a country that is highly dependent on oil or water is suddenly deprived of its source of supply by an embargo, it is likely to view such a deprivation as a national security threat. When public opinion polls indicatc that Canadians regard illegal migration as a threat to their security, at least the subjective side of Canadian national security has been engaged. It has been suggested that the most studied contingency is also the least 
likely. In planning for the 1990 s and beyond, policy makers must not be captured by the tendency to "prepare for previous wars, " they will be required to consider the possibility of a wide range of non-military threats to national security.

Opportunities for national security may take many forms. If a compassionate and generous nation-state is suddenly made aware of signs of a hardening of its citizens' attitudes against sponsorship of refugees, an intelligence communications opportunity to serve the public interest and the broader national interest may be presented to get the facts "out" to allow the public to reach an informed and objective judgement. Other intelligence opportunities or demands in the post Cold War period include arms control, proliferation, international trade negotiations and agreements, political positions of foreign governments on Canadian government policy initiatives, to name a few. Given the severe fiscal restraints, policy makers will have to carefully prioritize intelligence requirements to maximize benefits in the national interest.

\section{From What Sources?}

For most of the post World War II period, Canadian national security and intelligence efforts focussed on threats - sometimes real and sometimes perceived - stemming from the Soviet Union. One of the most important tasks at hand is to reassess the likely sources of national security threats in a multi-polar world. Increasing allegations of foreign government sponsored economic espionage suggests that economic intelligence 
activity may be on the ascendancy as nation-states redefine the role of their intelligence organizations. Asia, Africa, the former Soviet Union, the former Yugoslavia and the Middle East are likely sources of threats. In addition, friendly and even allied nation-states could pose threats in the new environment .

\section{In What Time Period?}

Choosing a time period on which to base national security policy is likely to be one of the key and most difficult choices confronting policy makers. In the aftermath of the Cold War, when major unforeseen changes are occurring, flexible and pragmatic policies and programs are required. New approaches and mechanisms are needed to ensure that appropriate political attention by the Prime Minister and Cabinet is devoted to priority setting ard planning for both the long term and the short term Canadian intelligence activity.

\section{By What Means?}

Having addressed the foregoing questions, policy makers must choose from a wide variety of means. The range of means includes maintaining strict neutrality, joining, creating or strengthening domestic or international alliances, refocussing security and intelligence organizations by abandoning or streamlining some functions and strengthening others, using non-security and intelligence capabilities to address 
particular aspects of concern related to a broader conception of national security, confronting potential adversaries with diplomatic or armed force or seeking security by trying to be accommodating "good neighbours". Strategic decisions are needed to establish what are the essential demands from a broad range of potential demands in a climate of declining resources.

\section{At What Cost?}

The utility of national security policy is a function not only of its effectiveness in protecting core values but also of cost, both social and fiscal. It would be a mistake to view the costs of national security solely in economic terms. Charles J. Hitch, foremost defence economist, explains that "there is no escape from the necessity of comparing, at the margin, net costs to the economy, for example, in other goods sacrificed, in inflationary pressures, in deleterious effects on efficiency, with net gains in security. ${ }^{\text {"72 }}$ Many of the most important costs of national security, however, involve the sacrifice of values that are not usually thought of as being part of the economy they are values that cannot be measured in terms of monetary market prices. For example, national security requires balancing values such as individual rights and freedoms, parliamentary accountability or a nation-state's image in terms of its commitment to promoting democracy and human rights. Effectiveness, accountability and affordability are the key drivers for Canadian intelligence reform. 


\section{Strntede Acende for Conndian Intelligence Polley}

The purpose of this thesis is to provide a strategic framework for Canadian intelligence activity that realizes the following objectives. First, the framework should help improve the management of Canadian intelligence activities at all levels and within all disciplines. Secondly, the framework should help improve Parliamentary and Executive accountability for Canadian intelligence activity. Thirdly, the framework should provide a clear, statutory confirmation of the responsibilities of all Canadian intelligence organizations. Finally, the framework should also provide an organizational structure that ensures Canadian intelligence collection and analysis is better integrated by optimizing the balance between centralization and de-centralization of program design and delivery. In this manner, Canadian intelligence should serve the national interest in a fair, effective, accountable, affordable and sustainable way.

The strategic framework confirms and clarifies a vision, mission and set of priorities for Canadian intelligence in a changed and changing world. Current statutes, programs, policies and organizational arrangements foster mediocrity by spreading capabilities too thin to identify and satisfy even the highest priorities. An inability to plan and invest for the long-term would leave Canada with inadequate assets to sustain programs to protect its sovereignty and pursue its vital national security interests. 
As a consequence, the plan proposed by this thesis reflects a departure from the status quo. The fundamental recommendation of this thesis is bifurcated, it focuses on two key variables - effectiveness and accountability. To improve effectiveness, security and foreign intelligence should be better integrated and the overall emphasis of Canadian intelligence activity should be shifted away from an operational mindset toward a strategic one. The provision of strategic intelligence analysis and advice that is useful to decision makers, particularly members of Cabinet, and vital to Canada's national interests is key to success. This recommended policy and program transformation is supported by a number of recommendations on organizational structure of the intelligence sector, such as consolidating existing major security and foreign intelligence organizations and creating others to address gaps. Therefore, in accordance with this thinking, the Canadian Security Intelligence Service, the Communications Security Establishment, the Security and Intelligence Secretariat of the Privy Council Office, among certain functions and resources of other departments or agencies should be grouped within a new stand-alone Department. Transformation also entails strengthening Canada's foreign intelligence collection capacity by establishing a small, specialized Canadian Foreign Intelligence Service to collect intelligence abroad in order to meet Canada's intelligence needs. Effectiveness of intelligence activity should also be improved by enhancing the assessments capacity.

In relation to accountability, the recommendations include strengthening the role of Parliament in national security matters, enhancing existing mechanisms for review and 
accountability, particularly the Security Intelligence Review Committee and the Inspector General of the Canadian Security Intelligence Service, by broadening their mandate and implementing a number of specific judicial and ministerial checks and balances to control certain operational activities of the security and intelligence organization.

A fundamental shift in Canadian thinking is needed to manage the transformation of security and intelligence requirements. At the core of the new directions proposed by this thesis is a new, lean, flat, relatively small and specialized organization dedicated to managing increasingly sophisticated challenges and opportunities. The proposed renewal plan builds on the evolution in Canada of the appreciation of security and foreign intelligence issues that may be traced back some fifty years. ${ }^{73}$ The proposed evolution of Canada's modern intelligence capacity reflects a growing awareness by the public and successive Governments of the need for intelligence as an instrument of statecraft.

This thesis articulates a vision for Canada's intelligence program. An assessment of the international, national, governmental and intelligence sector environments, and of Canada's consequent intelligence prioritics reveals the need for an integrated intelligence program. Canada will likely have a relatively high degree of national security whether or not the Government of Canada intervenes. The challenge for 
Government, then, is to manage the program in the national interest - minimize fiscal expenditures and other costs and maximize advantages for Canada. In part, Canada can achieve this goal by reallocating resources from the security intelligence program in order to place greater emphasis on the collection and analysis of positive or foreign intelligence to support government's broader agenda. Canada should exploit its comparative and competitive advantages as an open, democratic, culturally rich and internationally respected federation. Canada's intelligence goals should aim to strengthen national (and global) security by:

- focussing on Canada's economic and social needs in a global context;

- $\quad$ strengthening domestic, international and multilateral partnerships;

- developing flexible processes and policies which continually adapt to changing needs and circumstances;

- ensuring that national security policies and decision-making processes are fair, effective, efficient and as open as possible; and

- ensuring the program is accountable, integrated, effective, affordable and sustainable in the face of increasing fiscal pressures.

For Canada and its foreign partners, a credible intelligence program must produce more effective results. Better support for the national interest must be realized at lower direct and indirect costs, both social and fiscal. Better communication, 
consultation, openness and accountability can be realized by improving Parliament's understanding of the role and potential of Canadian intelligence. A national consensus based on Parliamentary support is required for an effective intelligence system. Managing the program will require strict adherence to support for Canadian statecraft and the national security policy-making process as the central focus of intelligence activity.

To realize this vision, a five point strategic agenda for Canadian intelligence policy is recommended. First, Government must focus the program on the national interest based on public input. The system must serve the needs of the federation as articulated by the federal government and the public. Key steps in this direction include integrating security intelligence and foreign intelligence, strengthening intelligence's links to government's broader social, economic, foreign affairs, humanitarian and trade objectives. Second, government must clarify and confirm, by statute, the core roles for all of Canada's intelligence organizations. Third, the mindset of intelligence practitioners must be strategic and not operational. The fundamental aim of the prugram should be the provision of strategic intelligence support to decision makers which is critical to the sovereignty, national security or national interest of Canada. Fourth, management of the program at all levels and within all disciplines must be improved and address the public policy question of how much risk of what kind (e.g., national security threats and opportunities) is acceptable to the public or assumable given the feasibility and the social and economic costs of 
managing that risk and the costs to service quality. ${ }^{74}$ New management strategies must be implemented to maximize declining resources and strengthen or create partnerships with departments, levels of government, international partners, the non-government sector and individual Canadian citizens. The challenging agenda for management is to consolidate, rationalize, redesign, integrate, and renew all intelligence programs across federal departments and agencies. A Business Plan outlining the vision, mission, mandate, environment, strategic directions and objectives of the program for which the Treasury Board would hold the Minister accountable is key to improving the management and the results of the program. Fifth, government must renew the structure and priorities of intelligence to strike an appropriate balance between the competing interests of effectiveness and accountability, and centralization and decentralization.

The Business Plan for the Department would establish, for the first time, an integrated corporate agenda for Canadian intelligence a tivity. This plan would be a key tool for guiding the transformation of intelligence priorities, processes, products and organizations to ensure best value for taxpayers' dollars in keeping with the Federal Government's core role and responsibilities in the federation. The proposed agenda covers 1995-1998. 


\section{Principles for Redetianing the Canndian Intellizence Seator}

This renewal plan for Canadian intelligence is founded on five basic principles. These principles are essential to ensuring the requirements of intelligence in safeguarding the national security of our democratic society and its institutions do not give rise to uncontrolled and abusive activities threatening civil liberties. ${ }^{73}$ The principles for transformation have been derived from those used to create the Canadian Security Intelligence Service. The principles were released by the Hon. Bob Kaplan. then Solicitor General of Canada, in the Government of Canada's statement on the publication of the Report of the Commission of Inquiry Concerning Certain Activities of the Royal Canadian Mounted Police ${ }^{76}$ in August 1981. The principles have enduring relevance.

First, Canada must have an effective intelligence organization capable of providing intelligence essential to the maintenance of our national security. Second, the intelligence sector must have an adequate statutory framework within which to conduct its activities in accordance with the rule of law and with full recognition of civil liberties, particularly the right to democratic dissent, or in accordance with the accepted norms of international behaviour. Third, the intelligence sector must have a management system that ensures effective internal direction and accountability, and respect for law. Fourth, the mandate and activities of the intelligence sector must be 
effectively accountable to ministers responsible to Parliament. Finally, effective external review is essential to ensure that the organization has not abused its powers or been misused by government.

The renewal plan is also shaped by five public interests. These public interests are based on those initially approved by Cabinet in 1989 to guide the activities of the Canadian Sucurity Intelligence Service." This thesis modifies and reorders the five key principles to reflect the public interest of the 1990 's and extends this guidance to all Canadian intelligence activities. In essence, the following description of public interests outlines what amounts to a broader definition of national security for Canada:

- Public Safety: the ability of Canadians and other persons within Canada to engage in ordinary social activity in the absence of threats to the core Canadian values of justice, tolerance and compassion which are hallmarks of our society and without fear that such values will be seriously damaged or lost;

- Economic Security: the fostering of innovation and best practices to facilitate economic growth, create jobs, foster a knowledge-based economy, and reduce unemployment, high long-term real interest rates, high levels of foreign indebtedness, and excessive government debt and deficits; 
- Integrity of Canada's Democratic Process: the functioning of those institutions, rights and freedoms fundamental to political sovereignty and the well-being of Canada's democratic society;

- Security of Government Assets: the responsibility of the Government to protect those human, intellectual and physical assets which it manages either in trust for, or in partnership with, the people of Canada; and

- International Peace and Security: the ability of the international system to evolve peacefully and assure Canadian territorial integrity in a changed and changing world characterized by globalization, unprecedented migration. extremist nationalism, proliferation, international criminal activity, religious fanaticism, environmental and health concerns.

The key challenge for Canadian inteliigence - with the disappearance of the old, single threat of Communism, real or perceived, that gave focus and meaning to security and intelligence for nearly fifty years - is to establish a new purpose, a new process to determine priorities, a new set of skills and knowledge, greater versatility, new approaches to accountability, and a flexible, more open approach to partnerships. Perhaps this means that security and intelligence is primarily about environmental scanning to support government's undertakings and provide information and analysis in 
response to government direction. Effective service to both direct clients and to the Canadian public and responsiveness to political direction are the sine qua non for intelligence in the post Cold War world.

The adjustment is and will be difficult. First, one should not underestimate how deep the Cold War ethos runs through all security and intelligence organizations. A massive shake-up may be needed to dislodge the Cold War mission and culture that drove them. A fundamental rethinking is appropriate. A premise of this thesis is that there are no "sacred cows" in the requisite review of statute, policy, program, process, people, skills, knowledge, and organization necessary to the renewal of Canadian intelligence. 


\section{CHAPTER 2. THE CANADIAN INTELLIGENCE SECTOR}

In the aftermath of the Cold War, there are a host of views on the state of intelligence and what to do with it. For example:

Intelligence is useful only to the extent that it provides objective value, support or re-assurance for proposed actions or policy. or alternatively gives warning that the proposed actions or policies are unlikely to achieve their objectives."

When it comes to the gathering of intelligence, we [Canada] are neither tame nor "neutral". In fact, we have become pretty good and aggressive at it. ... There is simply too much power behind those secretive walls at CSE's Heron Road Headquarters not to curb it in some way. ${ }^{79}$

The espionage blisiness ... was and is a self-serving sham. carried out by careerist bureaucrats who have managed to deceive several generations of ... policy-makers and the public about both the necessity and the value of their work. ... The information our ... espionage network acquires is generally insignificant or irrelevant to our policy-makers' needs....

Like every major modein state, Russia needs both a domestic security' service and a foreign intelligence agency. However, given the enormity of Russia's horrific history - the Stalinist Terror and the lesser crimes of the "years of stagnation" - Russians are bound to ask themselves if an organization such as the KGB can ever really be reformed. For it to possess an intelligence community worthy of its citizens' respect, Russia will have to close down the KGB and start afresh. ${ }^{81}$

These statements have been made by different people, each in a position to know whereof they speak, in response to separate circumstances. The statements do not represent new sentiments in the intelligence debate but they are not necessarily untrue. Each one warrants examination for the insight it may impart to the development of a plan to renew the effectiveness and accountability of Canadian intelligence activity. 


\section{Components}

Canada, like Russia, is facing a similar, if significantly less dramatic, crisis of legitimacy in security and intelligence. In the aftermath of the Cold War, the intelligence sector is not only desperately searching for a new mandate, but it faces a growing crisis in terms of its effectiveness and accountability. Canada, however, has a rare opportunity to rethink its intelligence requirements and to reconsider how the intelligence sector could best addresses them. And if intelligence work has been, for almost half a century morally bankrupt or practically useless, Canada should renew the goals and means of its intelligence capacity. In reviewing intelligence missions and mandates, it is now advisable to start with a clean slate. It is imperative to examine Canadian intelligence with the above quotes in mind, to see whether they have any validity and offer guidance for renewing Canadian intelligence.

In order to fully understand whether effectiveness and accountability are problematic for Canadian intelligence activity, it is useful to provide a brief description of the component parts and the inter-relationships of Canada's existing intelligence sector. Canada's intelligence sector, sometimes loosely referred to as Canada's "security and intelligence community," the "intelligence community" or simply the "community" consists of a number of federal departments and agencies which, collectively, are responsible for security and intelligence in Canada. 


\section{Parliamentary Sub-Committee on National Security}

At the apex of the external review regime for the intelligence system is the SubCommittee of the Standing Committee on Justice and the Solicitor General on National Security. The Standing Committee on Justice and the Solicitor General established the Sub-Committee on June 13, 1991. The Sub-Committee's mandate, as established by Order of Reference, is:

To undertake a review and consider the budgets and functions of the Canadian Security Intelligence Service (CSIS), the Royal Canadian Mounted Police's National Security Investigations Directorate (NSID) and their relationship with all agencies with which they have a Memorandum of Understanding or other working arrangements, and to sonsider the Annual Report of the Security Intelligence Review Committee (SIRC) to Parliament, all reports made by SIRC under s.54 of the CSIS Act, the Annual Statement of the Solicitor General with regard to national security, and the Public Annual Report from the Director of CSIS.

The Mission Statement of the Sub-Committee sets out the assumptions and priorities for the work of the Sub-Committee. Two explicit assumptions guide the SubCommittee, first, the belief that effective, responsive, and accountable security and intelligence is essential to the preservation and development of democratic political and social institutions. Secondly, Parliament, by ensuring that security and intelligence is responsive and accountable, ensures that security and intell.grave is also effective in the public interest. The Sub-Committee has six priorities. First, the Sub-Cummittee is responsible for carrying out Parliament's mandate in ensuring that security and intelligence activities and organizations are responsive and accountable. Second, it 
aims to ensure that the rights and freedoms of Canadians are respected by security and intelligence activities and organizations. Third, the Sub-Committee provides a forum for parliamentarians to review the security and intelligence activities of government. Fourth, it provides a focus for the consideration of security and intelligeswe issues by Canadians. Fifth, it aims to facilitate the implementation of all 117 recommendations contained in the September 1990 report of the Special Committee on the review of the CSIS Act and the Security Offenses Act entitled In Flux But Not In Crisis. Finally, the Sub-Committee will carry out its activities by conducting studies, holding public or in camera hearings and tabling reports in the House of Commons.

The Sub-Committee carries out its activities by considering key documents and issues including, the Annual Report of the Security Intelligence Review Committee, the Annual Statement by the Solicitor General of Canada with respect to national security, the public Annual Report of the Director of the Canadian Security Intelligence Service, relevant Main and Supplementary Estimates, relevant Order-in-Council appointments, and by identifying and considering important security and intelligence issues. In camera hearings have been held in order that the Sub-Committee may receive a limited amount of classified information. The Sub-Committee has taken a broad interpretation of its Onder of Reference. To date, the legitimacy of the self-proclaimed role, which extends beyond the security intelligence function, has not been formally accepted within the intelligence sector. 
Security Intelligence Review Committee

The Canadian Security Intelligence Service Act established the Security Intelligence Review Committee and the Inspector General as the two review bodies for the Canadian Security Intelligence Service. These mechanisms, the government believed, would be "vital to maintaining both the effectiveness and propriety of agency activities." ${ }^{\text {12 }}$ The control and accountability framework set up by the CS/S Act is comprehensive and, in some respects, unique. At the time of its establishment, there was "no analogue of these institutions in the existing security intelligence establishment." ${ }^{\text {} 83}$ Understanding the interrelated roles of the Review Committee and the Inspector General is key to understanding the accountability framework for CSIS and, equally important, the nature of the limited mandates of these review bodies visa-vis the entire intelligence sector.

The Security Intelligence Review Committee is Parliament's and the public's eye on CSIS. Ostensibly a non-partisan body, the Committee comprises five part-time members appointed by the Governor in Council after consultations between the Prime Minister and the leaders of opposition parties recognized in the House of Commons. The Committee has a dual mandate spelled out in the CSIS ACt - review and complaints. First, the Review Committee is to "review generally the performance by the Service of its duties and functions" and specifically, as established by section 40 of the CSIS Act, to ensure: 
...that the activities of the Service are carried out in accordance with this $A c t$, the regulations and directions issued by the Minister under subsection 6(2) and that the activities do not involve any unreasonable or unneciessary exercise by the Service of any of its powers..."

To fulfil its review function, the Review Committee has a number of specific, legislated responsibilities set out in section 38 of the Act." First, SIRC reviews the reports submitted to the Solicitor General by the Director of CSIS under subsection 33(1) of the Act and certificates of the Inspector General prepared under subsection 33(2). The Director's reports concern the operational activities of the Service and are prepared "in relation to every period of twelve months or such lesser period as is specified by the Minister"." The Inspector General's certificate to the Minister states "the extent to which the Inspector General is satisfied with the [Director's operational] report" and whether any act or any thing done by the Service in the course of its operational activities is in the opinion of the Inspector General unauthorized by law or Ministerial direction or involves an "unreasonable or unnecessary" exercise by the Service of any of its powers. Second, the Committee is responsible to review Ministerial directions to CSIS. Third, the Committee reviews and monitors domestic and foreign liaison arrangements entered into by the Service, including the provision of infurmation and intelligence pursuant to those arrangements. Fourth, the Committee reviews any report prepared by the Director of CSIS pursuant to subsection 20(2) of the Act concerning unlawful activities by employees of the Service in the purported performance of the duties and functions of the Service. Fifth, the Committee has a limited role in reviewing requests made by the Minister of Foreign Affairs or the 
Minister of National Defence pursuant to section 16 of the Act for CSIS' assistance in collecting foreign intelligence within Canada. Sixth, the Committee is responsible to review generally the regulations that apply to the activities of the Service. Finally, the Review Committee is responsible for compiling and analyzing statistics on the operational activities of the Service which are published in accord with the Committee's mandate.

\section{Inspector Gemeral of CSIS}

The statutory roles and functions of the Inspector General of the Canadian Security Intelligence Service are set out in sections $30-33$ and section 40 of the CSIS Act. The legislation specifies four duties for the Inspector General. First, the Inspector General must monitor the Service's compliance with its operational policies. Secondly, the Inspector General must review the Service's operational activities. Thirdly, for every period of 12 months, or a shorter period if required by the Solicitor General, the Director of CSIS has to submit a report on the operational activities of the Service to the Minister. With respect to each such report, the Inspector General must submit a certificate to the Solicitor General stating the extent of the Inspector General's satisfaction with the Director's report and whether, in the Inspector General's opinion, any act or thing done by the Service in the course of its operational activities during the period covered by the report was not authorized by or under the legislation, contravened directions issued by the Solicitor General to the Service under subsection 
6(2) of the $A c t$, or involved an unreasonable or unnecessary exercise by the Service of any of its powers. The Inspector General may also be required to review specific activities of the CSIS at the direction of the Security Intelligence Review Committee and to report to the Review Committee on such reviews."

The CSIS ACt sets out the relationships and access to information guidelines that are important for understanding the Inspector General's role and how it fits into the control and accountability framework for CSIS activity. The Inspector General is responsible to the Deputy Solicitor General. Therefore, the Inspector General is effectively a part, albeit a distinct and statutorily established part, of the Ministry of the Solicitor General. In accordance with the legislation, the Inspector General is required to submit certificates direct to the Solicitor General and, as mentioned, the Inspector General can also be tasked by the Security Intelligence Review Committee to undertake reviews.

The Inspector General has access to sny information under the Service's control that relates to the performance by the Inspector General of the four duties outlined above. Similar to the Review Committee, only Cabinet confidences may be withheld from the Inspector General. This exception does not appear to have hampered in any way the ability of either the Review Committee or the Inspector General to effectively carry out their responsibilities, respectively. In the case of Cabinet direction to the Solicitor General on government's annual national requirements for security intelligence, 
Cabinet's guidance is rewitten practically verbatim in the form of Ministerial direction to the Director of CSIS. This procedure allows both review bodies to have virtual access to the Cabinet confidences. In addition, the Inspector General is entitled to receive information, reports and explanations from the Service as the Inspector General deems necessary for carrying out his or her mandate.

The Inspector General was intended to be, and has performed as, the "eyes and ears" of the Solicitor General on the Canadian Security Intelligence Service. The Inspector General is not a functionary of the Service in order to maintain an appropriate degree of Ministerial responsibility." In this respect, the Inspector General is intermal to the Ministry of the Solicitor General, but external to the Canadian Security Intelligence Service. This arrangement, whereby by the Solicitor General has his or her own statutory review agency, is a reflection of the importance of government control of CSIS, as well as the sensitive nature of the framework within which the Service operates. 90

The respective roles of the Inspector General and of the Security Intelligence Review Committee are interrelated and clearly distinguishable. There are three key distinctions which help to explain why government established two review mechanisms for CSIS. First, the Security Intelligence Review Committee reports through the Solicitor General to Parliament and, ultimately, to the Canadian public. As such, it forms an important part of the process whereby Parliament can hold the government to account for the 
activities of CSIS. The CSIS Act establishes no relationship between the Inspector

General and Parliament. Instead, the Inspector General reports to the Solicitor General both directly and through the Deputy Solicitor General. The Inspector General supports Executive accountability by helping the Solicitor General hold the Service to account for those matters that fall within the legislated purview of the Inspector General."

Certain key reports prepared by the Security Intelligence Review Committee are public in nature, for example the Annual Report which is published each Fall. By contrast, all of the Inspector General's reports have a restricted audience and are classified as 'secret' or 'top secret.' As a result, the reports and certificates prepared by the Inspector General are less constrained by national security considerations of protecting sources, methods of operation and on-going operational activity that must be taken into account in the preparation of public documents.

Second, the legislated focus of interest of the Inspector General and the Security Intelligence Review Committee are not the same. The Inspector General is concerned with the Service's operational activities and compliance with regulations, policies and the law. The Review Committee's interest, in keeping with the public nature of the institution, is reviewing "generally the performance by the Service of its duties and functions"92 as well as to conduct enquiries into complaints by members of the public. 
Finally, the Inspector General was established to provide for an on-going review of CSIS operational activity. The government clearly did not intend to limit the Inspector General to "after the fact review of operations."93 Rather, the Inspector General has the function of ensuring that existing policies are being observed in order to provide assurance to the Solicitor General where such assurance is warranted and to give the Minister early warning of problem areas so that corrective action can be taken as quickly as possible. An analogy has been drawn between the Inspector General and the Security Intelligence Review Committee and the internal and external audit functions in the corporate sector. The role of the corporation's internal auditor is to undertake a continuous examination of the corporation's systems and controls and to report to management. This allows management to exercise control and make whatever corrections are necessary to get a "clean" opinion on the financial statements from the external auditor at the end of the fiscal year. As in the case with the Review Committee, the external auditor's report is a public document."

Although the analogy has merit, it is an oversimplification and should not be taken to suggest that the role of the Inspector General may be equated to an internal auditor of CSIS. The Inspector General's specific focus is on the Service's compliance with those authorities designed to maintain an appropriate balance between the rights of the individual in a liberal democratic society and the public interests of national security. For example, the Inspector General could be expected to be involved in assessing whether CSIS has complied with its operational policies and Ministerial direction in 
relation to recent allegations of CSIS activity and wrongdoing in the right-wing extremist and white supremacist milieu in Canada. By contrast, CSIS' internal auditors, similar to auditors in most government departments and agencies, focus on efficiency, economy and effectiveness issues. As such, it is a function that quite rightly reports to the Director of CSIS, rather than to the Solicitor General.

\section{Cabinet Committee}

At the top of Canada's security and intelligence sector, until recently, was the Cabinet Committee on Security and Intelligence, chaired by the Prime Minister. Its members included Ministers whose departments and agencies have primary responsibility for security and intelligence policy and operations, for example, Foreign Affairs, National Defence, and the Solicitor General. The objective of the Cabinet Committee on Security and Intelligence was to provide policy direction to both the security sector and the intelligence sector. However, the Cabinet Committee on Security and Intelligence, established in 1963, was disbanded as a result of changes to the cabinet committee system under the government streamlining process led by Kim Campbell. The Liberal Government under Jean Chretien has decided not to reinstate the Cabinet Committee on Security and Intelligence. Apparently, security and intelligence matters would be discussed in full Cabinet or at the Cabinet Committee on Social Development Policy, one of several ad hoc Cabinet Committees which include the Economic Development Policy and the Special Committee of Council. ${ }^{95}$ The extent of 
Cabinet's recent involvement in security and intelligence matters is not clear publicly. although in the Fall of 1994, Prime Minister Chretien indicated that other accountability arrangements for the Communications Security Establishment were under active consideration."

\section{Solicitor General}

The Solicitor General is described as "the linch-pin in the legal and policy framework" system established by the CSIS Act and the Security Offenses Act." Five major institutions, each managed by an official of deputy minister rank, comprise the Ministry of the Solicitor General. Four of these have direct operational responsibilities: the Canadian Security Intelligence Service, the Royal Canadian Mounted Police, the Correctional Service of Canada and the National Parole Board. A fifth entity, the Ministry Secretariat, headed by the Deputy Solicitor General, advises and assists the Solicitor General in relation to his or her full range of responsibilities, which in terms of the national security system are to provide direction to CSIS and the RCMP, exercise national leadership, and answer to Parliament. The Solicitor General is assisted in these matters by the Ministry's National Security Directorate (formerly the Police and Security Branch) and the Inspector General of CSIS. 
Ministerial control and accountability are exercised as set out in the CSIS Act. The Solicitor General has statutory authority to provide direction to the Director of CSIS through subsection $6(1)$ of the Act. It is the responsibility of the Solicitor General, on behalf of the Government of Canada, to define priorities for CSIS, and to establish the policy framework within which the Service implements the CSIS Act.99 Control refers to the Minister's "power of approval, the Minister's ability to set policy and give direction, and the means at the Minister's disposal to ensure decisions are implemented. ${ }^{\text {mo0 }}$ Accountability refers to the Solicitor General's obligation to answer before Parliament, and the duty of officials to answer to the Minister. ${ }^{101}$ The Act provides three specific requirements that constitute a principal means for Ministerial control beyond the normal rules of government that stipulate a Minister must be consulted on all important matters related to the Minister's portfolio. First, the Act requires the Service to obtain the personal approval of the Solicitor General prior to requesting Federal Court approval of a judicial warrant enabling the Service to use a range of intrusive investigative techniques. Second, the Service must obtain the approval of the Solicitor General to enter into an arrangement with other federal agencies and departments and provincial authorities and, in the case of arrangements with foreign governments, the Service must also obtain the approval of the Minister of Foreign Affairs. Finally, the Service must obtain the approval of the Solicitor General and a written request from either the Minister of Foreign Affairs or the Minister of National Defence, to provide assistance in the collection of foreign intelligence within Canada. 
Over the past decade, a strategic framework of "Ministerial directions" ${ }^{\text {102 }}$, issued to the Director of CSIS pursuant to subsection $6(1)$ of the CSIS Act, has been developed setting out the Solicitor General's governing $\mathbf{p}^{*}$.nciples for the Service and its activities. This strategic framework covers a wide range of issues including annual national requirements for security intelligence, arrangement's to assist the Director's accountability to the Minister, guidance on the Service's statutory duties and functions, instructions dealing with the Service's corporate management practices, among others. $^{103}$

In recent public documents, most notably the Annual Statement on National Security delivered by the Solicitor General in the House of Commons on April 1, 1993, the role of the Solicitor General in the national security system is described as having three main elements: security intelligence, security enforcement and protective security. However, the Solicitor General clearly has a foreign intelligence role by virtue of the Service's mandate under section 16 of the CSIS Act to assist in the collection of foreign intelligence within Canada. With the exception of the 1990 Government publication entitled On Course: National Security for the 1990s, the Solicitor General has rarely mentioned his responsibilities for foreign intelligence. Although the Security Intelligence Review Committee has recently begun to cover section 16 activity in its Annual Reports, the Review Committee has indicated some frustration in not being able to review the Service's section 16 activity to the same extent it does the Service's other activities. ${ }^{104}$ Despite the obvious importance of this policy area, not a 
great deal of information has been forthcoming on the matter. The Solicitor General rarely discusses in public his role and responsibilities in ensuring the effectiveness and accountability of CSIS's foreign intelligence activity. As a result of this shortcoming, neither the Minister's role nor the Service's in relation to foreign intelligence is well understood by Canadians. Foreign intelligence was not even mentioned by the Solicitor General in his 1992 or 1993 Annual Statcment on National Security. These omissions followed completion by CSIS in 1991-92 of an apparently major assessment of how the evolving security environment might affect the Service's mandate, resnucies and structure over time in the post Cold War world. ${ }^{105}$ In this case, government failed to live up to its commitment to adequately "provide Canadians with information about their national security system." ${ }^{106}$

\section{Canadian Security Intelligence Service}

The existing national security system was created in 1984 . The system removed the Security Service from the Royal Canadian Mounted Police and established in its place the Canadian Security Intelligence Service. The CSij Act described the several mandates assigned to CSIS, and the Security Offenses Act confirmed the RCMP's responsibility for security enforcement and protective security.

Parliament assigned CSIS a primary mandate and three secondary mandates which are articulated in the CSIS ACt. First. the primary mandate of the Service is its security 
intelligence function which is set out in sections 2 and 12 of the Act. Specifically section 2 defines "threats to the security of Canada" as:

(a) espionage or sabotage that is against Canada or is detrimental to the interests of Canada or activities directed toward or in support of such espionage or sabotage,

(b) foreign influenced activities within or relating to Canada that are detrimental to the interests of Canada and are clandestine or deceptive or involve a threat to any person,

(c) activities within or relating to Canada directed toward or in support of the threat or use of acts of serious violence against persons or property for the purpose of achieving a political objective within Canada or a foreign state, and

(d) activities directed toward undermining by covert unlawful acts, or directed toward or intended ultimately to lead to the destruction or overthrow by violence of the constitutionally established system of government in Canada,

but does not include lawful advocacy, protest or dissent, unless carried on in conjunction with any of the activities referred to in paragraphs (a)-(d).

Section 12 defines CSIS's core responsibilities in relation to the threats outlined in section 2:

12. The Service shall collect, by investigation or otherwise, to the extent that it is strictly necessary, and analyze and retain information and intelligence respecting activities that may on reasonable grounds be suspected of constituting threats to the security of Canada and, in relation thereto, shall report to and advise the Government of Canada. ${ }^{107}$

In 1990, the Solicitor General issued a Ministerial direction on sections 2 and 12 of the CSIS ACt in order to "provide guidance in respect of the operational interpretation of terms found in section 2 of the CSIS Act, and general policy framework to govern 
the Service's conduct of its security intelligence activities under section 12." ${ }^{108}$ In 1987, the Government took the decision to disband the Service's Counter Subversion Branch, and in 1988 the Solicitor General announced that Ministerial authorization would be required before the Service initiated an investigation, beyond open published information, of subversive activities defined by section 2(d) of the CSIS Act. No such authorization has been requested or provided.

Second, one of the Service's secondary mandates is the responsibility to provide security assessments to departments of the Government of Canada as provided for by section 13(1) of the Act. Subject to the approval of appropriate Ministers, CSIS may also enter into arrangements authorizing the provision of security assessments for provincial governments or departments, provincial police forces, and foreign governments, institutions, or international organizations. "Security assessment" is defined in the legislation as "an appraisal of the loyalty to Canada and, so far as it relates thereto, the reliability of an individual." ${ }^{109}$

Third, in accordance with section 14 of the $A c t$, the Service is mandated to provide information and advice in support of the government citizenship and immigration program. Section 14 states: 
14. The Service may (a) advise any minister of the Crown on matters relating to the security of Canada, or (b) provide any minister of the Crown with information relating to security matters or criminal activities, that is relevant to the exercise of any power or the performance of any duty or funciton by the Minister under the Citizenship Act or the Immigration Act.

Finally, the Service has a secondary mandate in the area of foreign intelligence that is carefully limited by Government under section 16 of the CSIS Act. Section 16 stipulates that:

16.(1) Subject to this section, the service may, in relation to the defence of Canada or the conduct of the international affairs of Canada, assist the Minister of National Defence or the Minister of Foreign Affairs, within Canada, in the collection of information or intelligence relating to the capabilities, intentions or activities of

(a) any foreign state or group of foreign states; or

(b) any person other than

(i) a Canadian citizen,

(ii) a permanent resident within the meaning of the Immigration Act, or

(iii) a corporation incorporated by or under an Act of Parliament or of the legislature of a province.

(2) The assistance provided pursuant to subsection ( 10 shall not be directed at any person referred to in subparagraph (1)(b)(i), (ii) or (iii).

(3) The Service shall not perform its duties and functions under subsection (1) unless it does so

(a) on the personal request in writing of the Minister of National Defence or the Minister of Foreign Affairs; and

(b) with the personal consent in writing of the Minister. ${ }^{110}$

The Service's foreign intelligence role was intentionally constrained by Parliament.

The legislation limits the Service's role to assisting in the collection of foreign 
intelligence within Canada. In addition, the Act requires the Service to obtain the personal consent in writing from two ministers before it may initiate any foreign intelligence collection activity. Furthermore, the Act prohibits the Service from targeting certain classes of persons in the collection of foreign intelligence.

\section{Royal Canadian Mounted Police}

The Security Offenses Act gives the RCMP primary responsibility for investigating offenses which arise out of conduct constituting a threat to the security of Canada or where a victim of an offence is an internationally protected person and for apprehending those who threaten the security of Canada or foreign diplomats in Canada. While CSIS pinpoints threats, the RCMP makes the arrests and assembles the evidence for prosecution. The RCMP works closely with other police forces inside and outside Canada in carrying out this responsibility.

There are four primary security related activities performed by the RCMP.

First, the Force is responsible for the prevention, detection, investigation and laying of charges in relation to security offenses referred to in the Security Offenses Act, or in other federal statutes such as the Criminal Code, the Official Secrets Act and the Export and Import Permits Act. Second, the RCMP is responsible for the provision of protective security measures to safeguard VIPs, federal properties, airports and vital points from security offenses or threats. Third, the Force provides advice to federal 
departments and agencies respecting protective security measures. Finally, the RCMP is responsible to consider threat assessments from CSIS and other sources to provide necessary protection to VIPs and special events.

Through its National Security Investigations Division, the RCMP exchanges information with CSIS and with other police forces on politically motivated crime, criminal activity by extremists and other national security matters. The National Security Investigations Division does not investigate specific offenses but collects, coordinates and disseminate criminal intelligence. It is also partly responsible along with CSIS for issuing terrorist alerts and preparing threat assessments with regard to foreign diplomats in Canada and dignitaries from abroad visiting Canada.

\section{Transp r rt Canada}

The security of the national transportation system - on land and water and in the air and its readiness to cope with emergencies is largely the responsibility of Transport Canada. The accent on airport security has been emphasized because of terrorist incidents in terminals and aboard aircraft in many parts of the world.

A Director General, Security and Emergency Planning oversees the work of four branches concerned with policy and plarning, security operations, intelligence, communications security and training, and emergency planning. 


\section{Cittrenship and Immigration Canada}

Citizenship and Immigration Canada has a number of intelligence related responsibilities and concerns. Key among them are attempts by terrorists to use Canada as a haven, as a base of operations or for transit. The Department is also concerned with political, economic or environmental developments abroad that lead to international migration movements that could bring legal or illegal immigrants or refugees to Canada. The Department is concerned with immigration rackets, including the organized smuggling of people into Canada and the production, sale and use of fraudulent documents.

The Department is developing a strategic approach to intelligence to ensure that intelligence serves the full range of Departmental activity, from strategic and operational policy development to program delivery and resource allocation based on a formalized risk management methodology. In terms of intelligence products, the Department is concerned with both strategic and tactical intelligence. Under the tactical heading, the Department develops and takes part in the development of programs for detecting fraudulent immigration practices - for example, distributing copies of newly-discovered forgeries to ports of entry so officials there will know what to look for. Strategic intelligence includes background briefing papers, immigration 
studies and trend analysis regrading enforcement and control activities. During recent years, the intelligence function has been strategically linked to the Department's interdiction efforts overseas with considerable success."'

\section{Revenue Canada (Customs)}

The Customs Intelligence component of Revenue Canada, Customs is a support service responsible for collecting, evaluating, collating, analyzing and disseminating intelligence on actual, suspected and potential Customs violations and trends. This may include commercial fraud irregularities, export control, smuggling activities, intercepting terrorists and trends, or other violations of concern to Canada Customs. The resultant intelligence, both tactical and strategic, is provided to support the enforcement efforts of Customs and other national (e.g., RCMP, CSIS and Citizenship and Immigration) and international departments and agencies, and to Revenue Canada, Customs senior management for the formulation of policy decisions. ${ }^{112}$

\section{Foreign Affairs and International Trade Canada}

One of the key goals intended to increase the effectiveness of Canada's foreign policy program is to ensure that political and economic reporting is moving toward more targeted information gathering, intelligence, analysis and advocacy. ${ }^{113}$ This objective 
has had a significant effect on at lewst two of the department's four Functional Branches, namely the Political and International Security Affairs Branch and the International Business Development Branch.

The Political and International Security Affairs Branch is concerned with enhancing Canada's sovereignty and security, and contributing to international peace, stability and laws. The Branch develops and implements foreign policy in three specific areas: international security and arms control, international organizations, and security and intelligence. With respect to the latter, the Security and Intelligence Bureau is focussed on international terrorism, security and safety of Canadian government premises and employees and their families overseas, internationally protected persons in Canada and intelligence matters related to foreign policy.

In 1992-93, the Security and Intelligence Bureau was active in providing ministers, senior government officials and policy makers with "timely and critical intelligence on world events." ${ }^{\text {114 }}$ The International Business Development Branch is concerned with contributing to Canada's economic growth by helping Canadian business to succeed globally. It carries out this activity by gathering information on export markets, investment and technology opportunities and by providing it to industry to help firms develop international business strategies. ${ }^{1 / 5}$ The Branch achieves its objectives primarily through the work of the Trade Commissioner Service. Stuart Farson has noted that the Trade Commissioner Service has been told to focus on "commercial 
intelligence" rather than "commercial information." This implies a shift in emphasis of the mandate from open sources of information on business practices and factors to confidential information in such areas. ${ }^{116}$

The Trade Commissioner Service is Canada's largest international commercial and economic intelligence gathering network. 117 It has Canada-based and locally engaged officers located in more than 100 offices around the world, who specialize in matching identified trade, investment and technology opportunities and potential with the needs and capabilities of firms in Canada. "Market information and intelligence is their principal product." 118 The Trade Commissioner Service also plays an important and growing role in identifying international business opportunities, providing advice on market access, advocating Canadian policies and positions on various trade and economic issues, and monitoring international developments that can affect Canada's trade and industry. ${ }^{119}$ Efforts to improve the market intelligence product and its dissemination to Canadian firms continue.

\section{Department of National Defence}

The Chief, Intelligence and Security is responsible for the collection, production and dissemination of defence intelligence, including scientific and technical inteiligence, for the Canadian Armed Forces. A Director General, Intelligence and a Director General, Security report to the Chief. The Director General, Intelligence has five specific areas 
of responsibility, defence intelligence, current intelligence, imagery exploitation, scientific and technical intelligence and intelligence plans and doctrines. The Director General, Intelligence also has responsibility for maintaining liaison with intelligence agencies in other countries.

\section{Communications Security Establishment}

The Communications Security Establishment (CSE) is an important element of Canada's foreign intelligence program. CSE is responsible for two programs, the information technology security (INFOSEC) program and the signals intelligence (SIGINT) program. Under the INFOSEC program, CSE provides technical advice, guidance and service to the Government on the means of ensuring Federal Government telecommunications security and on aspects of electronic data processing security. CSE also provides cryptographic key material and documentation to departments and agencies. Under the SIGINT program, CSE collects, studies and reports on foreign radio, foreign radar and other foreign electronic emissions in order to provide foreign intelligence to the Government in support of Canada's foreign, defence and security intelligence programs and policies. ${ }^{120}$

The Minister of Defence is accountable to Parliament for CSE. The Minister approves CSE's major capital expenditures, its annual Multi-Year Operational Plan and, presumably, with the support of an ad hoc Cabinet Committee (following termination 
of the Cabinet Committee on Security and Intelligersce under the previous

Government) major CSE initiatives with significant policy or legal implications. ${ }^{13}$ The Chief of CSE is accountable to the Deputy Minister of National Defence for financial and administrative matters, and to the Deputy Clerk (Security and Intelligence, and Counsel) in the Privy Council Office for policy and operational matters. ${ }^{122}$ In addition, arrangements for Department of Justice legal counsel, for interdepartmental consultation, and for administrative review through National Defence's internal mechanisms constitute the accountability system for CSE. In March 1995, a private member's bill on the establishment of a review mechanism tor CSE received the Prime Minister's support and was passed in the House of Commons. In the final analysis, this mechanism may be more analogous to the IG of CSIS than to SIRC, but the addition of another bureaucratic structure fails to address some of the key systemic issues outlined in this thesis .

\section{Joint Task Force Two}

In 1986, the government established a new anti-terrorist team, known as the Special Emergency Response Team (SERT), under the RCMP as Canada's elite armed counter terrorism force of last resort. The RCMP spent approximately $\$ 42$ million to train and equip the unit during the $1986-1993$ period. The 49 member team was never used against terrorists. In 1993, the government transferred the team to the Department of National Defence and it was renamed Joint Task Force Two (JTF2). Information on 
the size, tactics, capabilities, organization and identity of team members are classified for security reasons. The main purpose of the team, however, is to act as a "force of last resort" in dealing with terrorists or major disturbances affecting Canada's national security. The team could have a secondary mandate related to VIP protection or internationally protected persons. In 1993, the Department of National Defence released information that it intended to spend $\$ 20$ million over the next two years on JTF2. ${ }^{123}$

\section{Privy Council Office, Security and Intelligence Secretariat}

The primary function of the Privy Council Office (PCO) is to support the Prime Minister and Cabinet in the operation of the central policy decision-making process and to provide information and advice to the Prime Minister in the conduct of his or her responsibilities as head of the Government of Canada and Chair of the Cabinet. The PCO has a central role in the coordination of government activities. It communicates the will of the Prime Minister to the rest of the federal bureaucracy. ${ }^{124}$

The role and mandate of the Coordinator, Security and Intelligence Secretariat generally addresses four broad areas: security and intelligence policy; departmental security services, including for the Privy Council Office, the Prime Minister's Office and the Deputy Prime Minister's Office; interdepartmental intelligence assessments; and policy guidance to the CSE. ${ }^{125}$ Despite the importance of this function, it is "not 
clear that the PCO's role in security and intelligence matters is exercised to its fullest capacity." ${ }^{126}$ During the Five Year review of the CSIS Act and the Security (Offensess $A c t$, the Security Intelligence Review Committee (SIRC) "expressed some concern that the coordination, assessment and dissemination of intelligence in the government may not be functioning as well as it should be."12i By 1990, the Cabinet Committee on Security and Intelligence, created in 1963, was not meeting on a regular basis and, by implication, not providing the necessary leadership to guide Canadian intelligence. ${ }^{2 n}$

\section{Department of Justice}

The Department of Justice may be establishing a limited capacity to better support Department of Justice legal counsel to CSE. ${ }^{129}$ According to On C'ourse, Justice also had a lead coordination rolefor an interdepartmental working group assigned responsibility to improve the use of security intelligence in judicial proceedings.

\section{Effectiveness and Accountability}

The Canadian intelligence sector is fragmented. Both its structure and processes are widely dispersed which raises concerns about the effectiveness and accountability of the sector. A number of examples may be cited in this respect. First, at the apex of the system, Parliament's understanding of and support for intelligence work has been uneven and questionable. Second, at the Cabinet level, the committee structure which 
existed since 1963 was disbanded in 1993. It has yet to be replaced with a new focal point at the Cabinet level. Third. the mandate of both the Parliamentary Sut Committee on National Sec urity and the Security Intelligence Review Committee exclude major components of the Canadian intelligence sector. Fourth, although security intelligence and foreign intelligence are increasingly interrelated, the management and design of the intelligence sector fosters overlap, duplication and barriers which inhibit integration, cooperation, effectiveness and accountability. Fifth, the statutory framework for the direction and control of intelligence is unbalanced, applying only to CSIS. Sixth, the strategic intelligence needs of the government are less than adequately scrved. Agreement on the need for intelligence assessments can be elusive when cooperation among intelligence components is impeded by parochical bureaucratic interests. Seventh, the strategic direction of Foreign Affairs' intelligence efforts, particularly concerning commercial and economic intelligence, poses important questions that have yet to be asked or answered in public. How far are Foreign Affairs employees permitted to go in collecting and producing intelligence to protect or advance the interests of Canadian corporations? To what extent does CSIS or CSE assist? Is cooperation and coordination optimal, overlap and duplication minimized?

\section{Program Review Process}

This thesis assesses Canada's existing intelligence sector and programs, outlined above, through the Program Review lens. The result is a renewal agenda for major change 
and improvement of Canadian intelligence activity. The Government of Canada committed in the February, 1994 Budget to a range of policy and program reviews:

In order to reduce costs and provide Canadians with the best services affordable, the Minister of Intergovernmental Affairs and Public Service Renewal will lead a review of all aspects of departmental spending to ensure that lower priority programs are reduced or eliminated and that the government's diminished resources are directed to the highest priority requirements and to those areas where the federal government is best placed to deliver services. ${ }^{130}$

This commitment provided the basis for the Program Review, a comprehensive examination of all federal government programs and activities. However, to be effective in renewing Canadian intelligence, this thesis modifies the Program Review approach in the following manner. The Program Review 'template' is applied against the whole intelligence sector, rather than the departmental approach taken by the actual Program Review conducted in 1994-95. This modification is necessary as a result of the fragmented nature of the intelligence sector and the need for Canada's post Cold War intelligence organizations to adopt a horizontal pan-departmental focus to support the government's broader agenda and to help dev. sin a common federal policy framework and program structure.

A modified Program Review, then, provides an excellent opportunity for considering the kinds of change necessary to improve the management, effectiveness and accountability of Canadian intelligence as a whole. One of the fundamental problems with Canadian intelligence, as noted by Stuart Farson, is that "no one seems to be 
evaluating whether the intelligence sector as a whole is effective."131 A completely new approach to intelligence in Canada is required in the post-Cold War era. First and foremost, an answer is needed to the question "What should intelligence do in the public interest?" This focus represents a major change from the past. This new approach requires an altogether different level of strategic thinking supported by flexible management that is unfettered by "old" intelligence conventions such as the need-to-know principle and compartmentalization.

The Program Review has four basic objectives which could serve as a strategic lever to renew Canada's intelligence programs:

- to examine federal programs and activities systematically to ensure that they continue to be relevant to the public interest and that they are redesigned and implemented in such a way that they represent the best value for taxpayers' dollars;

- to help renew the Canadian federation by clarifying the federal government's program and policy responsibilities in relation to those of other orders of government and other sectors of society and, in particular, by identifying further candidates for eliminating overlap and duplication between the federal government and the provinces; 
- to ensure government programs and activities are delivered through the best delivery mechanisms (e.g., line departments, Special Operating Agencies, Crown Corporations, Partnerships, Commercialization, etc.); and

- to assist the government in implementing budget cuts that have already been announced to date and in realizing any further savings required to meet medium-term fiscal goals.

At its broadest level, the Program Review asks departments to assess their programs and activities from the point of view of their policy mandate. Essentially, how would a department renew itself to fulfil its public interest mandate within a steadily declining budget? Canada's intelligence sector should be asking itself as a whole what role it should perform because for the for the first time in half a century, dramatic changes in national security and intelligence policy, at the international and national levels, have become politically feasible. This circumstance was due largely to three factors integral to the new political environment which are likely to endure for at least the next five years:

- $\quad$ end of the Cold War;

- increasing fiscal pressure on government; and

- increasing public pressure for better results from government. 
A number of key additional pressures compel a fundamental rethinking of the core roles, responsibilities and organization of Canadian intelligence. First, as discussed, the international and domestic threat environment has changed dramatically as a result of the collapse of the Soviet Union. Second, the term "national security" has become too ambiguous. Third, the doctrine of "executive privilege" has been eroded and the public is demanding more effectiveness, accountability, and openness from government. Fourth, the Canadian intelligence system is, and is increasingly seen to be, fragmented and unbalanced which raises faimess, effectiveness, affordability and accountability issues. Fifth, the Auditor General is scheduled to begin in fiscal year $1995 / 96$ the first ever program audit to broadly assess the accountability of Canada's intelligence sector. This review could take more than a year to complete and may provide empirical data to support fundamental changes outlined by this thesis. Sixth, major reviews of Canadian foreign policy, defence policy, citizenship and immigration policy are well advanced. The results of these policy reviews should be used to frame and develop new priorities and policies for Canadian intelligence activity linked to government's broader agenda. Seventh, intelligence systems of foreign allies or friendly nation states have been reviewed and significant changes have been proposed in the United States, Britain, Germany and Australia, respectively. Significant changes have been implemented in Australia where security expenditures were reduced by $30 \%$ and wholesale management changes made. Denmark disbanded its foreign intelligence service. Germany restructured its counter intelligence capacity in a reunited Germany and developed plans to treat "friendly" allied services as hostile foreign services. 
German plans could include the United States, France and Britain because those countries were expected to increase their intelligence operations in Germany to determine the political direction the new Germany will take and to keep the perceived economic dominance of a united Germany in Europe under surveillance. ${ }^{132}$ Finally, allegations of impropriety concerning CSIS activity within Canada's extremist rightwing milieu and of non-accountable spying on the part of the CSE, ${ }^{133}$ whether completely true or not, bighlight systemic deficiencies in the intelligence sector. These developments point to the need for renewal. Unaddressed effectiveness and accountability issues in the intelligence sector will inevitably lead to public outrage and overwhelming domestic political pressure for drastic changes in the event of an intelligence failure, the risk of which increases in the absence of reforms.

The Program Review established six tests which are provided verbatim below. They were applied against all of Canada's intelligence programs and activities in order to fundamentally rethink Canadian intelligence and to provide a renewal plan to improve its management, effectiveness and accountability. Effective intelligence in a liberal democracy is the basic goal. Accordingly, the proposed plan aims to establish a fair, effective, accountable, affordable and sustainable Canadian intelligence program.

Public Interest Test: Does the program area or activity continue to serve a public interest? Yes. Canada requires an intelligence capacity to protect its sovereignty and core values from internal and external threats and to pursue opportunities in support of 
government's economic, social, foreign policy, defence, trade, citizenship and immigration objectives.

Role of Government Teat: Is there a legitimate and necessary role for government in this program area or activity? Yes. Government has a legitimate and necessary role in intelligence to ensure the protection and pursuit of Canada's national interests. Given an increasing emphasis on economic matters in the context of national security, government must be careful not to duplicate the role and functions of industry, particularly concerning industrial espionage where the potential for overlap and duplication is high.

Federalism Test: Is the current role of the federal government appropria $z$, or is the program a candidate for realignment with the provinces? The federal government has primary responsibility for Canada's intelligence programs and, therefore, Canada's intelligence programs are not a candidate for realignment with the provinces.

Partnership Test: What activities or programs should or could be transferred in whole or in part to the private or voluntary sector? There is a requirement to ensure government's intelligence collection and assessment efforts do not duplicate knowledge, or capacities to produce knowledge, that already exist elsewhere in society. Partnerships with other federal government departmints, other levels of government, the non-government sector and with foreign intelligence organizations are integral to 
an effective intelligence program. Areas of strong potential for strengthened partnership include collection and assessment in the fields of economic security. environmental security, international organized crime, drug trafficking and illegal migration, proliferation of weapons of mass destruction, and migration and population trends.

Efiiciency Test: If the program or axtivity continues, how could its efficiency be improved? Canada's intelligence programs essentially fail the efficiency test. Overlap and duplication between departments and agencies was not of paramount concern during the Cold War era. Compartmentalization and perceived risks associated with creating an intelligence monolith, in effect, encouraged wide-spread duplication. For example, intelligence analysis activity is still carried out in isolation by the Canadian Security Intelligence Service, the Communications Security Establishment, the Privy Council Office and the Department of Foreign Affairs. For intelligence organizations generally, the Cold War era provided an environment that was premised on a heightened need for security and secrecy surrounding routine work processes such as the collection, handling, storage and retrieval of information. Zero tolerance for risk contributed to the establishment of expensive, time consuming and labour intensive modes of work, often at the expense of effectiveness. Compartmentalization meant that exchanging information between work units within a single organization or between organizations was often time consuming or simply did not occur. 
Canadian intelligence should be repositioned to realize efficiency and effectiveness gains within the context of a fundamental restructuring of the world economy. This means that a renewal agenda for intelligence must contribute to deficit and debt reduction. The new economy has significant implications for the expansion of information and the transfer and use of knowledge. Intelligence must reflect the new role of information, communication and knowledge in society, or it will become costly, irrelevant or misleading. ${ }^{134}$ Consolidation of Canada's intelligence programs in a new departmental structure will realize economies of scale and, as discussed later, will enhance accountability. Amalgamation and renewal of programs such as the government security screening process are key to resolving at least the obvious efficiency problems within Canada's intelligence programs.

Affordability Test: Is the resultant package of programs and activities affordable within the fiscal constraint? If not, what programs or activities would be abandoned? The resultant package of programs achieved through consolidation of Canada's intelligence sector is not affordable. Expenditure reduction, program rationalization, process redesign and a formal risk management approach would complement program renewal and help to focus Canadian intelligence activity to ensure that it is affective, accountable, affordable and sustainable. 
The Program Review approach adapted by this thesis confirms and clarifies the core roles for Canadian intelligence and of the proposed Department of National Security as follows:

- lead the establishment of an integrated framework for and management of Canada's intelligence and national security policy, including the direction and management of strategic intelligence (including security intelligence and foreign intelligence as subsets) objectives and requirements and operational decisionmaking and review;

- pursue and protect the national interests and national security interests of Canada by focussing on the following:

- $\quad$ strategic intelligence: generate and provide strategic intelligence and advice to the Government of Canada to enable integrated policy and legislative decision-making vital to Canadian statecraft and to Canada's national security interests;

- foreign intelligence: collect information and intelligence, within Canada or abroad, regarding the capabilities, intentions, or activities of foreign powers, organizations or persons, which pertain to Canada or Canada's vital $\mathbf{n}$. 'ional security interests, 
- counter-terrorism: prevent acts of serious, politically motivated violence against Canada or Canada's vital national security interests, within Canada or abroad;

- counter-intelligence: prevent or mitigate acts of espionage or hostile foreign intelligence activity against Canada or Canada's vital national security interests, within Canada or abroad; and

- $\quad$ security screening: rationalize and streamline the security screening function in order to provide, on a strictly necessary basis, personnel security assessments, information and advice to federal government departments and agencies; provincial governments or departments; provincial police forces; and foreign governments, institutions, or international organizations.

This thesis identifies a void in Canadian statecraft. The intelligence sector is presently unable to identify and meet Canada's strategic intelligence needs. Strategic intelligence is the major prerequisite for the successful conduct of a nation-state's increasingly interrelated international relations and domestic affairs. Adda Bozeman strongly asserts that strategic intelligence is: 
...indispensable in anarchical times like ours when the technically unified world is morally and politically too divided and conflicted to assure a modicum of order and security to its diverse constituencies. ${ }^{135}$

The core federal roles in the intelligence sector, as outlined above in the chapter entitled The Canadian Inselligence Sector, should continue. The Government of Canada must, however, address significant systemic failure or inciapacity to apply existing old systems of accountability, advice or knowledge rooted in the Cold War to new problems in a rapidly changing world. As a result, the goals, roles, methods and organization of the intelligence sector should be renewed and transformed in a manner that supports government-wide efforts to achieve the following six general objectives. First, the government needs to modernize federal programs and policy infrastructures. Second, there is a need to reduce the size of government and the level of government intervention in the lives of Canadians. Third, there is a need to address the fact that the federal government is overextended because policy is not properly linked by a common framework. Fourth, the government must address the growing gap between revenues and expenditures. Fifth, government must respond to the concerns of Canadians who are becoming increasingly critical of how government works and are increasingly demanding better service. Finally, the government must replace traditional, across-the-board cuts which tend to foster wide-spread mediocrity in the public sector, with a more sensible way to manage fiscal restraint.

This thesis proposes a new mission for Canadian intelligence that shifts the emphasis of intelligence activity away from a focus on operational or case specific "threats" 
toward a focus on Canada's strategic interests. Canada requires a versatile intelligence capability. Radical changes in the international system should remind government that Canadian intelligence policy, as well as defence, foreign and immigration policy, should not be based solely "on what we think will happen, but rather on the explicit premise that, because we do not know what will happen, we must be ready for a wide range of possibilities. ${ }^{n 136}$ The renewal agenda and related strategies should contain contingency plans to address sudden changes, threats or opportunities.

Intelligence must inform decision makers in a timely way about the capabilities, intentions and accions of nation states with interests that are either similar to or in conflict with Canada's. The intelligence capacity will need a strategic focus which produces intelligence analysis at a governmental level. The program should be based on a clear and publicly shared understanding of the meaning of the notion of "intelligence" and of "national security." A stronger role for Parliament and the public in understanding the security environment and the role of intelligence and in shaping the purpose for government's intelligence activity is integral to sound public policy in this area of government activity just as it is elsewhere. 


\section{CHAPTER 3. STRATEGIC FRAMEWORK FOR CANADIAN INTELLIGENCE}

A major conclusion of this thesis is that the mandate and organization of Canadian intelligence must be better integrated. New partnerships need to be developed based on a strategic plan designed to enhance both the effectiveness and accountability of Canadian intelligence. The framework is based on the five fallacies and eight questions regarding national security that were addressed in Chapter 1 of this thesis.

The first consideration of the strategic framework is how much security is reasonable for Canada or how much risk Canada faces and to what level government should manage national security. Canada will have a relatively high degree of national security (or relatively low degree of risk) whether or not the Government of Canada intervenes. But naivete and gullibility about reality should not obstruct the adoption of a broad conception of national security for Canada in the post Cold war world. And a realist's perspective translates into significant demands for intelligence support to the protection and pursuit of national interests. As Deputy Minister V. Peter Harder noted in 1993 in a memorandum to all employees of the Department of Public Security:

Government in the 90's and beyond is not, and cannot be about doing everything. It is about choices - hard choices. strategic choices, and thi: in turn will require that we be able to identify and weigh relative risks. ${ }^{137}$ 


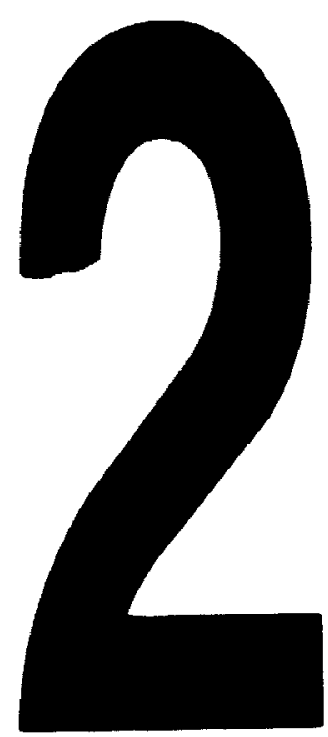

PU-1 3\%"x4" PHOTOQRAPHC MCROCOPY TARCET nos wrea AMsi/bo 22 EOUNALENT

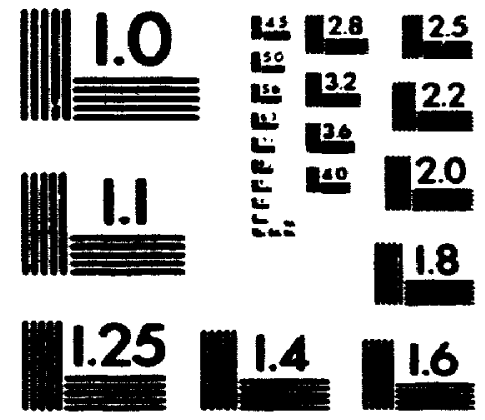

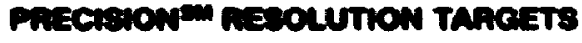


The intrinsic value of timely and accurate intelligence is evident in view of both the increased level of international competition and the critical role of knowledge in postindustrial society. The declining importance of common, strategic military threats has decreased the need for allied and friendly nation-states to share intelligence at a time when, in comparative terms internationally, Canada's intelligence sector is small and dependent on foreign cooperation. International competitiveness. expanding free trade zones and relative comparative advantages among nation-states means that nation-states may be allies or friends in some areas and rivals in others, and it is increasingly difficult to distinguish between the two. Given this, it is imperative that Canadian intelligence be configured and tasked in a manner that optimizes expenditures.

Second, the strategic framework addresses the kind of security that Canada needs. Canada's national security interests must be defined as much in economic, political, social and, perhaps even environmental, terms as in military ones. National security interests related to sovereignty and territorial integrity will be shaped by health and safety considerations and by culture and national identity, as well as concern for control of borders.

Third, the strategic framework articulates which values should be protected or promoted. The contribution of Canada's national security program should be sharply refocussed by the law, by the Prime Minister's leadership within the context of an ongoing intelligence priorities setting process, and by the government's social, 
economic, foreign affairs, trade, citizenship and immigration objectives. In this way, Canadian intelligence will have a well defined role in support of the five public interests described in greater detail in Chapter 1:

- Public Safety;

- Economic Security;

- Integrity of Canada's Democratic Process;

- Security of Government Assets; and

- International Peace and Security.

Fourth, the strategic framework addresses the kinds of threats and opportunities Canada must manage and the level to which they should be managed. Canada's national security program must aim to protect Canada's core national security interests. The major threats to Canada's security are posed by terrorism, proliferation of military technology and weapons of mass destruction - nuclear, biological and chemical, emergence of religious fanaticism, espionage against Canada or Canada's vital national interests, illegal migration, and international narcotics-trafficking. Canada has a significant requirement for political intelligence to determine the capabilities and intentions of other nation-states and economic intelligence in support of Canadian firms and government's broad objectives to create jobs and provide stability and safety for Canadians. Canada has significant requirements for military intelligence tied to its overseas peacekeeping missions and the increasing threat of proliferation. 
Fifth, the strategic framework outlines the sources of threats to Canada's national security. One of the most important consequences of the end of the Cold War is the disappearance of a unifying principle around which national security programs were designed, namely the principle of containment for the international threat of Soviet and Sino inspired communism. Which nation-states will constitute the important threats to national security during the remainder of the 1990 s and beyond? Changes in the international environment since the late 1980s have blurred once clearer distinctions between one's friends and those whose friendship is less manifest or reliable. ${ }^{138}$ This fact, insofar as intelligence organizations are concerned, is likely to mean that governments will increasingly use intelligence resources against friends and allies. Canada's intelligence efforts should be adjusted based on a consideration of the implications for Canada resulting from these changes.

Another potential source of increasing national security concern is posed by the activities of non-government agencies with security and intelligunce roles, particularly in relation to commercial and economic espionage. Radical departures from conventional usage of the term national security will need to be considered, principally perhaps as a means for de-emphasizing military or other traditional aspects of national security. Richard H. Ullman ${ }^{139}$ has developed the following definition:

A threat to national security is an action or sequence of events that (1) threatens drastically and over a relatively brief span of time to degrade the quality of life for the inhabitants of the state, or (2) threatens significantly to 
narrow the range of policy choices available to the government of a state or to private nongovernmental entities (persons, groups, corporations) within the state.

The effect of the above definition would be to expand the notion of national security to include "acts of God", such as epidemics, droughts, floods, and earthquakes. Such a departure from conventional usage is not recommended for Canadian intelligence. However, threats to the quality of life emanating from deterioration of the environment should receive increased intelligence attention in the future in accordance with the government's contribution to the peaceful evolution of the international system.

The new approach must recognize that intelligence and diplomacy are not mutually exclusive. They are derivatives and expressions of the particular society, culture, or ideology in terms of which they are being activated. In short, there are as many types of this statecraft as there are actors practicing it in world politics at any given time. ${ }^{140}$ Axiomatically, Canadian intelligence should know how political intelligence plays elsewhere in the world, particularly in relation to Canadian interests. To do otherwise could foster naivete in decision makers. For Canada, a premise of this thesis is that intelligence lies somewhere in the middle of a conceptual continuum with diplomacy at one end and military preparedness or warfare at the other. Intelligence overlaps at both ends of the continuum. The extent of overlap depends on circumstances. (The role of intelligence in relation to diplomacy and warfare is developed further in the section entitled Effectiveness and Canadian Intelligence: Partnerships.) 
A definition of requirements and priorities depends. in some measure. on an analysis of current intelligence holdings. An identification of areas or subjects that require further intelligence collection will be shaped by new government requirements and priorities. Precision in matters of defining requirements and priorities is key to collection and analysis relating to both operational and strategic intelligence needs.

Sixth, the strategic framework articulates a time period for planning. Canada should develop a Business Plan for its national security and intelligence program based on a three year period. It would, in effect, serve as a continual program review. Each three year period should begin with a comprehensive assessment of the environment and the strategic and operational performance of the national security system. The review should provide a measurement of effectiveness and accountability based on results and serve as the basis for ongoing planning and renewal. This approach is intended to ensure that national security policy is an integral component of each government's mandate within a regular election cycle in Canada. A three year cycle is a reasonable period given the difficulty of making accurate long-term national security forecasts in a rapidly changing environment. This planning period should be complemented by an annual operational and expenditure management planning cycle led by the proposed Minister of National Security. Annual Planning Meetings and quarterly meetings of Cabinet on national security matters, chaired by the Prime Minister should be a fixed feature of the strategic planning process for intelligence. As a strategic document, the Business Plan should be used to meet Central Agency 
expenditure and planning requirements and serve as a basis for ministerial accountability, communications to Parliament, Canadians and to the employees of the proposed Department of National Security.

Seven, the strategic framework focusses on the means to protect and pursue national interests. Having addressed questions about the kind and amount of security to pursue, which national values should be protected, the nature and sources of threats, and the planning period, policy makers must choose from a wide variety of means to pursue the objectives. Canada needs a stronger strategic intelligence assessment capability. Development of a process for sharing access and contributions to a 'warehouse' of intelligence and information pooled by federal departments wo:ld support the analysis function. Targeted security and foreign intelligence collection activities, a rationalized security screening capability and stronger domestic and international partnerships are the means that Canada should develop. In addition, similar to the existing policy framework for CSIS activity, all means of investigation and collection of information or intelligence should be proportionate to the gravity of the threat and the probability of its occurrence, the importance of the opportunity or urgency of the situation. Possible damage to civil liberties is another key factor which must be weighed in making targeting decisions. As a matter of principle, the least intrusive means of investigation should be used to protect or pursue interests, except in cases of urgency or when other methods are not available or practical. ${ }^{141}$ Canada has to decide which of a variety of means are appropriate to the circumstances. 
Eight, the strategic framework addresses the cost of national security. National security activity must be undertaken only to the extent that the costs justify the benefits to Canada. The utility of a national security policy and program is a function not only of its effectiveness in protecting core values but also of its fiscal, social and political costs. Secret power should not run free of supervision. "The enduring irony of intelligence is its potential to destroy as well as to guard democracy." 142 Canada can realize the interdependent objectives of effectiveness and accountability by establishing a statutory framework for the entire intelligence sector. Consolidation and integration of security and foreign intelligence would help to confirm and clarify requirements and priorities. The establishment of a strategic intelligence assessment capability close to, but separate from. both the producers of raw intelligence and the consumers of intelligence should help to improve the efficiency, effectiveness, performance, relevance and utility of intelligence.

Given the current fragmented nature of intelligence organization in Canada, much can be done to reduce intelligence expenditures. Canada should be able to reduce intelligence expenditures by 30 to 40 percent without a significant reduction in the level of security or capacity to support the pursuit of other national interests. Consolidation of the intelligence components into a single department would significantly reduce costs tied to overhead, overlap and duplication of effort. Consolidating and streamlining the security screening function alone, currently 
performed in part by the Department of National Defence, the Royal Canadian Mounted Police and the Canadian Security Intelligence Service, would produce significant savings.

In recent years, the security screening function performed by the Canadian Security Intelligence Service has been improved through renewed Government Security Policy, automation, efforts to decrease the need for security clearances, a reduction in the number of lengthy "information" briefs, and other process improvements. ${ }^{143}$ In 1990 91, the CSIS received approximately 65,000 requests for security clearances. Only once did the Service recommend denying a security clearance. Furhermore, it is unclear from available information whether or not the individual was, in fact, denied the clearance. In 1993-94, the Service processed nearly 43,000 security clearance requests from various federal departments and agencies. The Security Intelligence Review Committee stated in its 1993-94 Annual Report:

From our point of view, it is long past time that the number and level of security clearances required again be rigorously re-evaluated. We believe such an evaluation could reasonably be expected to recommend drastic reductions. This would save a considerable amount of scarce resources that are now, in our opinion, expended unnecessarily. ${ }^{144}$ 
It is apparent that Canada is not getting good value for its dollar in certain areas of the intelligence program. Even factoring in a deterrence effect caused by the screening function, it appears that marginal increments of additional security are pursued at enormous fiscal and social cost to direct clients and to Canadiali taxpayers. A formal risk management framework would improve the management of security screening. The extension of profiling, now conducted by the immigration screening program, and random sampling would eliminate many of those 43,000 requests. Coupled with a strong deterrent (e.g., loss of employment and other rights or privileges), a comparable level of security could be realized at drastically reduced fiscal and social cost. Significant reductions in social costs would flow from curtailing government intervention into the lives of Canadians inherent in current security screening proccesses.

\section{Strategic Framework: Accountability}

The proposal to create a Department of National Security raises a range of accountability issues fundamental to Canadian democracy. Yet, the proposals are based on the belief that any realistic plan to improve Canadian intelligence in the public interest must strike a "delicate balance"145 between the needs of national security and the principies of democracy. The creation of the Department of Public Security under the Conservative Government led by Kim Campbell caused a backlash from special interest groups contributing ultimately to the Liberal Government's decision to 
disband the fledgling department. The Department of National Security would be different than Public Security Canada. The Department of Public Security was a sensible step in that it diversified the client base for security intelligence and fostered the integration of security intelligence into the mainstream of government activity. Unlike Public Security, the Department of National Security would integrate security and foreign intelligence into a broader range of government objectives.

The primary mandate of the Minister of National Security would be to provide strategic intelligence in support of government-wide policy and program initiatives. This activity would be carried out under a comprehensive and overarching review and control regime. By contrast, the existing accountability regime for Canada's security and intelligence activity is uneven. Effectiveness and accountability are interdependent and both can be achieved together. Greater attention to this bifurcated objective is needed than current circumstances provide. The realization of one, however, does not guarantee realization of the other.

Accountability in modern government is far more complex and multi-dimensional than in theory. According to theory, the public service and bureaucrats are fully and directly accountable to ministers, their political leaders, and then ministers are responsible and accountable to parliament, and through parliament to the public. Critics have concluded that the doctrine of ministerial responsibility not only does not work much of the time, but that it is also only one of many types of accountability 
that affect a bureaucracy and bureaucrats. At least six torms of accountability are important: to clientele; to peers in the public service: to parliament and public: (I) political leadership; to the courts; and to themselves and their professional standards. ${ }^{\text {th }}$

If the question of accountability for the public service generally is confusing and obscure, then it is doubly difficult for intelligence services. The need for secrecy to protect the identity of individuals, groups or processes from public disclosure (whether sources of information, targets of intelligence attention or methods of operation) "conspire to make most of the accountability of intelligence inward and self-directed." This makes the task of accountability, which is already problematic for any government department or agency, doubly difficult for intelligence organizations. ${ }^{147}$

The requirements of intelligence in safeguarding the national security of Canada's democratic society and its institutions must not give rise to uncontrolled and abusive activities threatening civil liberties. ${ }^{148}$ Canada and other liberal democracies face a unique challenge in maintaining the security of the nation-state. That challenge is to secure democracy against internal and external threats, without destroying democracy in the process. ${ }^{149}$ If the doctrine of reason of state established an absolute and overriding priority and right to govern at all times and all places, there would be no problem: whatever the nation-state did to preserve itself would be legal and acceptable. regardless of the affronts given to civil liberties and democratic process. But in liberal democracies, the government as well as the people is expected to live under and within 
the law. The powers and the rights of the government are described and limited by the legal and constitutional framework. The rights of the people include freedom of speech and assembly, freedom from arbitrary arrest and detention, rights to a fair trial, rights to privacy, and in general the right to go about public and private business without interference or control by the state. Our system is one of rule of law. ${ }^{150}$ In protecting Canada and Canadians against espionage, terrorism or other threats to the nation-state, the police, military, national security forces, and other branches of government ought, in liberal democratic constitutional theory, to be limited by the law of the land.

Effective intelligence within a democratic framework is the fundamental precept which should guide any prescription for renewal of Canadian intelligence activity. The existing system of parliamentary accountability for the Canadian Security Intelligence Service is the basic model. The accountability framework for CSIS is premised on the need to protect the principles of democracy based on the exhaustive study and report of the McDonald Commission in 1979-81. This Commission was established after allegations of serious misbehaviour by members of the security service had been made. The Commission found many of the allegations to be justified, and in its report recommended sweeping changes to the conduct of security activities, including its separation from the Royal Canadian Mounted Police, its "civilianization", a new law to govern it, and a vastly improved system of accountability. Not surprisingly then, given the context of the time, the framework for security intelligence activity enacted 
in 1984 by the Trudeau government strongly emphasizes the requirement of protecting the principles of democracy. This system provides an adequate model for the regime proposed by this thesis for Canada's entire intelligence sector.

The current system of review for Canadian Security Intelligence Service activity is comprised of three basic components. ${ }^{\text {st }}$ First, its foundation is the legal framework within which intelligence activities are performed. Second, the system has a chain of accountability and responsibility by which people and organizations are made accountable and responsible to Parliament. Third, the system features a set of procedures and instruments available to Parliament to make the process of accountability effective. This system is relatively complex and countervailing (i.e., it features checks and balances) in design to ensure the system is 'self-correcting.' However, certain malfunctions in one component risk systemic breakdown. For example, systemic integrity is being challenged because some practitioners, scholars and members of the public believe that the Security Intelligence Review Committec has become a "lap-dog" not a "watch-dog." Others believe the credibility of the system is jeopardized because, in their view, the system places too much emphasis on review to the point where operational effectivess is adversely affected. 
The review system is comprised of interlocking actors (Solicitor General, Minister of National Defence. Minister of Foreign Affairs, Director of CSIS, Deputy Solicitor General, Commissioner of the RCMP, Inspector General of CSIS, Security Intelligence Review Committee, Attorney General of Canada, Justices of the Federal Court, and the employees who carry out their responsibilities and roles within the framework). This system, however, applies only to CSIS. For this fundamental reason it is inadequate. It does not cover the entire intelligence sector. The 'achilles heel' of Canada's existing control and accountability system for intelligence, then, is its limited purview in law and scope. The Security Intelligence Review Cemmittec and the Inspector General do not have an accountability mandate for the activities of the Communications Security Establishment, Privy Council Office, Foreign Affairs or other components of Canada's intelligence sector. This constitutes the key "weak link in the chain of accountability" 152 for Canadian intelligence.

A renewal plan is needed to address the growing doubt about the doctrine of "executive privilege" (to use a British term) as an adequate underpinning or authority for the operation of security and intelligence services in liberal democracies. In Canada, there are increasing demands for greater openness and growing intolerance with government secrecy and existing accountability regimes for security and intelligence activity. Informed public debate is required to establish a new understanding and agreement on the compatibility of secrecy and democracy. Such a debate would help shape the strategic decisions and trade-offs required to renew 
Canada's intelligence programs. The new direction should be based on an accepted and shared understanding by government and the public of the level of tolerance for secrecy, risk (or threat to national security) and the exercise of executive privilege and the capacity of government to deliver. The new organizational model which aims to strengthen both Executive and Parliamentary accountability by encompassing the entire intelligence sector would demonstrate government's commitment to ensuring that political control is, and is seen to be, exercised effectively. ${ }^{153}$

\section{Legal Framework}

A core recommendation of this thesis is that Canada requires a new statutory framework for its intelligence activities. The entire intelligence system should be placed on a statutory footing, entitled the Canadian National Security Act. The Act would incorporate, modify and update the Canadian Security Intelligence Service Act, the Security Offenses Act, the Official Secrets Act and include additional provisions necessary to implement the recommendations set out in this thesis. Specifically, the Canadian National Security Act would provide definitions of "intelligence" and "national security." The Act would articulate the mandate, roles and responsibilities for Canadian intelligence and provide an accountability framework for intelligence activity. For example, the Act would require prior approval of the Minister of National Security before an operational arm of the Department could apply for a Federal Court warrant authorizing the use of intrusive investigative techniques. 
Furthermore, this system would implement additional requirements to control the use of human sources. The Act would establish appropriate mechanisms for redress and complaints. Finally, the $A c t$ would serve to consolidate and integrate the organizational components of Canadian intelligence.

The Department of National Security would be built from a number of existing or new organizations and positions. The Parliamentary Standing Committee on National Security would replace the existing Sub-Committee on National Security of the Justice and Solicitor General Standing Committee. The Department would be headed by the Minister of National Security. The Department would consist of the Deputy Minister of National Security, the Inspector General of National Security, the Assistant Deputy Minister, Foreign Intelligence Sector, who would be responsible for the Communications Security Establishment and a new Canadian Foreign Intelligence Service, the Assistant Deputy Minister of Strategic Assessments and Corporate Services which would include analysis components of the current Security and Intelligence Secretariat of the Privy Council Office, the National Security Directorate of the Solicitor General Secretariat and resources from the Research, Analysis and Production Branch of the Canadian Security Intelligence Service and from the RCMP, Citizenship an. ' Immigration Canada and National Revenue (Customs). In addition, the Department would include the Assistant Deputy Minister, Security Intelligence Sector, who would be responsible for the Canadian Security Intelligence Service and Security Screening Services. 
In 1991, the Government rejected a similar, albeit less ambitious, recommendation made by the Special Committee in its report to Parliament on the five-year review of the CSIS Act. ${ }^{154}$ Similar ideas are under active consideration elsewhere in the world. In the United States, an omnibus Bill, entitled the Intelligence Reorganization Act of 1992 proposed sweeping changes to United States intelligence programs to ensure they changed with the world and provided for "improved management and execution of United States intelligence activities." 153

In the United Kingdom, a series of recent initiatives under Prime Minster Major's "openness" policy of government led to the enactment of the Inselligence Services Act 1994 on May 26, 1994. ${ }^{156}$ The Act placed the British Secret Intelligence Service (SIS or M16, the UK's foreign intelligence agency) and the Government Communications Headquarters (GCHQ, the UK's signals intelligence organization) on a statutory footing for the first time, officially acknowledging and providing for the continuance of both SIS and GCHQ. Official acknowledgement of the British Security Service (BSS or MI5) came when it was established by statute under the 1989 Security Service Act. The Intelligence Services Act also established a Parliamentary Committee known as the Intelligence and Security Committee to examine the expenditure, administration and policy of the BSS, SIS and GCHQ. ${ }^{157}$ Committee members are sitting Members of Parliament or Lords, and cannot be Ministers of the Crown. ${ }^{158}$ Committee members will have access to classified information with certain qualifications. The Act empowers the Secretary of State to issue warrants to the BSS, SIS, and GCHQ for the 
purpose of authorising "the entry on or interference with property or with wireless telegraphy." ${ }^{199}$ Finally, the $\mathrm{ACt}$ provides for the issuance by the Secretary of State of similar warrants on the application of the BSS on behalf of the SIS and GCHQ. ${ }^{100}$

Two key additional accountability requirements for operational intelligence activity are proposed by this thesis. The first requirement would ensure the Communications Security Establishment and the proposed Canadian Foreign Intelligence Service, as the Canadian Security Intelligence Service does today, obtain prior Ministerial approval to apply for a Federal Court warrant to use in Canada or abroad intrusive investigative techniques, such as mail opening, entering or removing anything from certain premises, and intercepting telephone, fax, computer or other communications. Such warrants would be valid for a specified period, usually one year or such lesser period as may be imposed by the Minister or a judge of the Federal Court. This system would be adapted from the current regime that guides CSIS operations.

The second requirement would be entirely new. It concerns the use of human sources in the collection of both security and foreign intelligence. Use of human sources is probably the most intrusive investigative technique available to an intelligence service. As noted by the current Director of CSIS, Ward P. D. Elcock, this technique may be a fiscally cost effective investigative method in comparison to technical interception by satellite or other sophisticated means. On the other hand, it also entails greater risks. Human sources may act over zealously on their own volition or misinterpret guidance 
from their case officer or "handler." Currently, CSIS tasks human sources in accordance with the CSIS Act, two Ministerial directions issued by former Solicitor General Pierre Blais to former Director of CSIS, Reid Morden, and CSIS operational policy. A judicial warrant is not needed to use a human source. Current practice requires the personal approval of the Minister or the Director to use confidential sources where the human source is involved in the most sensitive institutions of our society, such as the "academic, political, religious, media and trade union" institutions. ${ }^{161}$ It is proposed that human sources used by Canadian intelligence should require prior Ministerial approval and judicial approval. This additional requirement is proposed in light of the continuing importance of this investigative method, the sensitivity attached to it, as well as the potential serious adverse impact that such use can have on society. This accountability requirement can be implemented in a manner that does not hinder legitimate operational requirements. This requirement would apply specifically to directed, paid and long-term human sources and all sources involved in the most sensitive institutions of society.

Previous cases provide evidence of the need for effective measures to control the use of human sources. Serious concerns have surfaced publicly in the past which related to the degree to which such investigative techniques might have involved an unnecessary or unreasonable exercise by CSIS of its powers. One example involved Marc Boivin who was arrested and charged with criminal offenses on June 4, 1987. Prior to that time he was a human source for CSIS and its predecessor, the RCMP 
Security Service, for approximately 15 years. ${ }^{162}$ Another example involved CSIS' alleged misconduct and use of Grant Bristow as a source of information on white supremacist activities in Canada during 1989-94. ${ }^{163}$ The Security Intelligence Review Committee's recent review of CSIS' conduct in the so called "Heritage Front Affair" found that:

CSIS had placed a human source in the Heritage Front and its associated organizations. We concluded, furthermore, that CSIS was correct to investigate the leadership of the extreme right and we were satisfied with the level of targeting which the Service approved. ${ }^{104}$

The Role of Parliament

Parliament is the body which calls the government to account. There is a solid argument that this should ixe as true for intelligence activities as for other programs. ${ }^{165}$

The McDonald Commission held this view, and recommended a new mechanism to ensure stronger involvement of Parliament in intelligence matters. The general thrust of the following observation is equally relevant and valid today:

Parliament requires an enhanced capacity to scrutinize security and intelligence activities. The necessarily secret nature of these activities makes it impossible for Parliamentary scrutiny to be exercised effectively through any mechanism other than a small committee whose members either include the party leaders or are specifically selected by them. This Committee's effectiveness will depend on its capacity to develop and maintain the confidence of all parliamentary parties, as well as that of the government and the security [and intelligence] agency[ies]. ${ }^{106}$ 
The McDonald Commission further recommended that the scope and scrutiny of the reviewing bodies should:

...extend to the activities of all those intelligence collecting agencies and departments of the federal government whose activities involve the use of covert techniques of investigation. ${ }^{167}$

In both instances, the Government's decisions regarding control and accountability for CSIS and for national security matters generally fell short of McDonald's recommendations. In other words, a comprehensive review structure was implemented only for CSIS. The third Director of CSIS, Ray Protti, remarked before the SubCommittee on National Security of the Standing Committee on Justice and the Solicitor General that:

In looking at the CSIS Act I was struck by the emphasis in the legislation on the review process. A full third of the Act is devoted to review. This is a clear reflection of the concerns and the intent of parliamentarians in the drafting of the legislation. ${ }^{160}$

Given this past record, future renewal efforts aimed at strengthening accountability for national security should further examine Parliament's role in these matters. Although Parliament's adoption of the CSIS ACt did not impose any restriction limiting its oversight role of security and intelligence activities, Parliament was expected to play a limited role in national security matters. The Security Intelligence Review Committee was envisaged almost as "the surrogate" for Parliament in relation to security intelligence activity. Given constraints on access to classified information and the 
partisan nature of Parliamentary debate, it was felt that Parliament was ill equipped to carry out the role. The nature of the role envisioned for Parliament, in part, was explained in the Canadian Security Intelligence Service Explanatory Notes accompanying Bill C-157 (which also applied to the enacted legislation for CSIS) and the Government's Statement on the publication of the McDonald Commission Report:

Under current Parliamentary rules, the annual report of the Security Intelligence Review Committee submitted to Parliament will be referred to the appropriate Parliamentary Standing Committee. Parliament will, therefore, have both the opportunity and the responsibility to review the report and assess the activities of CSIS. ${ }^{169}$

The CSIS Act clarified, extended and confirmed Parliament's oversight role in relation to the activities of CSIS. Part IV, Section 56 (1) of the CSIS Act and Section 7(1) of the Security Offenses Act placed an obligation on Parliament to conduct a comprehensive review of the provisions and operation of the respective Acts following five years of experience with the legislation and delegated this responsibility to a "committee of the House of Commons or of both Houses of Parliament as may be designated or established by Parliament for that purpose."170 Subsections 56(2) and $7(2)$ respectively completed the accountability chain by requiring the cummittee to table its report in Parliament. ${ }^{171}$

Independent of the CSIS Act, but shortly after its passage, the House of Commons extended the capacity of standing committees by expanding their powers in conducting enquiries and reviews of matters under their jurisdiction which gave them discretion to 
decide when to make inquiries and to address matters they believed relevant and reasonable. Parliament's new rules also strengthened the accountability process by requiring the Government to respond to committee reports within 150 days when specifically requested to do so. ${ }^{172}$

In accordance with the rules of Parliament, the Government published On Course: National Security for the 1990s in response to the Special Committee's Report on the Five Year Review of the CSIS Act and Security Offenses Act. The purpose of On Course was to explain how the national security system was functioning, to address the major issu:s raised by the Special Committee and to explain:

... how the control, accountability and review arrangements work in practice, and thereby assure Parliament and the puhlic that a high degree of confidence in these arrangements is warranted. ${ }^{173}$

The Minister also publicly committed the Government to "arrange for another Parliamentary review" of the CSIS Act and the Security Offenses Act beginning in 1998. The Government's response to the Special Committee's 117 wide-ranging recommendations for legislative, policy, program, organization, human resource, management and process change to the security and intelligence sector is summarized in a key paragraph in the Solicitor General's foreword to On Course:

There may be reasons to open the two Acts for amendment in the future, given evolving jurisprudence and the continuing development of the new system. But the Government does not believe legislative changes are required at present. In many cases where the Special Committee has recommended 
amendments to deal with issues, the Government believes further policy development would address the concerns raised. In other cases, further review of the functioning of the national security system is required before definitive judgements can be made. The Government does not favour altering the intricate system of checks and balances established by the Acts. So far, these have served Canadians well in ensuring effective national security with due regard for the fundamental rights of individuals. But confidence in the system can be improved by providing Parliament with more information on security issues.

Shortly after publication of On Course in February 1991, Parliament created a SubCommittee on National Security of the Standing Committee on Justice and the Solicitor General. To date, the Sub-Committee has been largely ineffectual, in part, because the main interests of the Standing Committee on Justice and the Solicitor General are focussed on other issues. ${ }^{174}$

The existing Parliamentary accountability structure for national security is vulnerable for two basic reasons. First, the fragmentation of responsibility for intelligence matters among a range of Ministers raises doubts as to their knowledge about or concern for this area of their responsibility. In the two recent Annual Public Statements on National Security by Solicitors General, the foreign intelligence assistance mandate of CSIS was not acknowledged as being one of the Service's secondary mandates (along with security screening) and therefore a key area of Ministerial accountability. ${ }^{175}$ The CSIS Public Annual Report, which accompanies the Minister's annual national security statement, also neglected to mention the Service's foreign intelligence role. ${ }^{176}$ Second, in relation to the exercise of Ministerial responsibility, the Security Intelligence Review Committee and the Sub-Committee on National Security have a limited 
capacity for making credible public assurances that secret national security activities are being conducted properly, given the limited mandate of these bodies. The lack of a review body with recognized responsibility to ensure control and accountability for all Canadian intelligence activity entails significant political risks. The potential for another intelligence scandal (e.g., allegations that CSIS helped to create and fund the white supremacist Heritage Front in Canada and allegations that weak accountability permitted CSE to use electronic surveillance to target Quebec politicians) is likely to draw increasing attention to basic flaws in the control and accountability system.

\section{National Security Review Committee}

This thesis recommends strengthening Parliamentary and public accountability for Canadian intelligence activity by replacing the Security Intelligence Review Committee with a new National Security Review Committee. The new Committee would have a mandate covering all of the security and intelligence activities of the Department of National Security and, therefore, of the entire security and intelligence sector. Members of the National Security Review Committee, a quasi-judicial body, would be appointed according to a process similar to that governing the appointment of judges of the superior courts of every province, the supreme courts of the Yukon and Northwest Territories, the Federal Court of Canada and the Tax Court of Canada. ${ }^{17}$ Advisory committees would assess candidates for membership on the National Security Review Committee. As is the case with judges, committees would be asked to assess 
candidates according to established criteria of qualifications against three categories "recommended", "highly recommended" and "unable to recommend". The Commissioner for Federal Judicial Affairs would have overall responsibility for the administration of the appointments process on behalf of the Minister of National Security. Appointments to the National Security Review Committee would be made by the Govenor in Council on the advice of the federal Cabinet. Before making a recommendation to Cabinet, the Minister of National Security would consult senior members of the judiciary and the bar. ${ }^{178}$ The National Security Review Committee would be expected to act in the national interest by conducting objective, non-partisan reviews of sensitive national security issues. The Committee's reporting requirements to the Minister of National Security and to the Parliamentary Committee on National Security would parallel the existing Security Intelligence Review Committee model.

\section{Executive Accountability}

As currently configured the Canadian intelligence sector is too fragmented and isolated from the government process it is intended to serve. Political leadership and authority is dispersed across the intelligence sector. The tools, structures and decision-making processes, therefore, are either inadequate or non-existent for setting priorities, allocating resources and ensuring they match capabilities and support a strategic direction. Of fundamental concern is the apparent lack of a business plan to manage the strategic directions and expenditures for the intelligence sector as a whole. The 
lack of such a plan diminishes the likelihood that the bureaucracy will develop the capacity necessary to provide quality and timely support to ministers.

Perhaps paradoxically, the post-Cold War era demands that Canada's intelligence capacity become more flexible and capable of anticipating, understanding and levering maximum benefit to the national interest from change. The structure proposed by this thesis would strengthen executive accountability in three primary ways. First, it would strengthen Ministerial responsibility for policy, program, priority setting and expenditures for intelligence matters through the creation of a Minister of National Security and a strong role for Cabinet and the National Security Review Committee. Second, the proposed organizational configuration would strengthen coordination and support for the Minister through a single Deputy Minister with statutory responsibility and other mechanisms, such as the Inspector General, for the management and direction of Canada's intelligence program under the guidance of the Minister of National Security.

The above management structure would encourage change in the mindsets of managers away from agency-oriented perspectives toward partnerships, integration and strategic objectives. Third, creation of an independent strategic intelligence assessment group within the Department would ensure the function is properly located within government, that is, close to operations but not of them, close to policy and decision making but not politicized. This structure would also ensure that the analytical 
function and resources are neither too scattered nor located in a single analytic "bullpen." Location of the assessment function is key to ensuring better support for the intelligence planning process and the needs of the most important intelligence consumers, the Prime Minister, Cabinet and senior decision makers in the bureaucracy. Linking the strategic assessments function to the government's top priorities and national security needs is key to its success.

\section{Cabinet}

Much has been written about the theory of the intelligence cycle. Policy or decision makers advise the heads of intelligence organizations what they need to know, intelligence gathers and analyzes the information, provides the intelligence to decision makers, and the decision makers formulate policy. In reality, the system is not as simple or straightforward as this simplistic model. In fact, policy and decision makers rarely frame requirements for intelligence. Former United States President George Bush fully acknowledged this on November 15, 1991 when he launched the National Security Directive Number 29 to fundamentally re-assess American intelligence capabilities and requirements for the 1992-2005 period:

Senior policy makers traditionally have neglected their critical role in setting intelligence priorities and requirements. The revolutionary world of today and tomorrow, the huge uncertainties we face, the constraints on our resources, and the need to ylan well ahead all make it imperative that each of you take a personal interesi in this effort. ${ }^{19}$ 
In reality, collection and analytic functions operate in parallel. Intelligence does not actually drive the decision process in most cases and security considerations tend to be forgotten in the cycle, which emphasizes 'positive' intelligence. ${ }^{100}$ The intelligence capacity needs clear direction. It can have a niche and it must focus on it. To paraphrase Dr. Emest May, if the Prime Minister wants intelligence to confirm or deny the existence of a growing population of blind rabbits in Argentina, it won't suffice to direct intelligence to find out about the state of the eyesight of rodents in South America. ${ }^{181}$

To provide the intelligence sector with adequate direction, this thesis recommends that Cabinet adopt an active posture on security and intelligence matters. Cabinet must do more than respond to crises. Its leadership should be visible, continual and credible. Credible leadership entails providing strategic direction for Canadian intelligence. Such direction will establish policy directions and ensure statutory changes enable implementation of new policy directions. This approach should be feasible as long as Cabinet remains relatively small, approximately 20 members. If Cabinet grows, then consideration should be given to establishng a Cabinet Committee on National Security. To support Cabinet, this thesis recommends replacing the existing Deputy Minister level Interdepartmental Committee on Security and Intelligence with a similar committee to be known as the Canadian National Security Committee, chaired by the 
Deputy Minister of National Security. The role and advice of the Deputy Minister support Committee on National Security would be to inform and advise Cabinet. The Committee of Deputy Ministers would support Cabinet in its efforts to establish intelligence priorities within a strategic framework, ensure integration of, and appropriate balance among, security and foreign intelligence activities, capabilities, resources and expenditures. In this way, government will focus on ensuring that the overall performance of Canada's intelligence sector is both effective and accountable.

The previous Cabinet Committee on Security and Intelligence was defective in three fundamental ways. The Committee met neither regularly nor frequently. It appeared only to be called into action in crises. Second, it appeared to react to the policy proposals of lower committees rather than initiate policy itself. Third, there were no individual ministers responsible for specific aspects of national security and intelligence policy. ${ }^{182}$ The McDonald Commission recommended ways to revitalize the Cabinet Committee on Security and Intelligence during the 1980s by involving it more in the priorities setting process. That thinking would be supported by creating the Minister of National Security. A Minister, then, would be responsible for foreign and security intelligence policy, programs and product. Full Cabinet involvement in decision-making on intelligence policy, program and priorities would be key given the breadth of issues to be discussed and their relevance to a range of portfolios and 
government's agenda. Ministers of the Crown at the Cabinet table would represent intelligence consumers as well as producers, thereby contributing to a comprehensive assessment of trade-offs and risks.

\section{Centralization and Coordination}

Centralization of intelligence is a contentious issue for a democracy. Three concerns about centralization of intelligence have been part of the intelligence debate in Canada over the years. There is concern about the extent to which centralization risks creating an uncontrollable intelligence monolith in a liberal democratic nation-state. Second, the amalgamation of various intelligence functions together in a single organization risks a contagion effect. Foreign intelligence operating principles may adversely influence security intelligence modus operandi which is based on respect of the rule of law. Third, the objectives of a security intelligence service are fundamentally different than those of a foreign intelligence service and, therefore, different controls are required for different services. ${ }^{183}$

In the post-Cold War World there is merit in revisiting these issues to determine whether the current division of intelligence labour maintains an appropriate balance between accountability and effectiveness. In contrast to the McDonald Commission 
report, the Report of the Special Committee of the Senate on the Canadian Security Intelligence Service, chaired by the Honourable P. Michael Pitfield, Delicate Balance, recommended that:

CSIS should not only assist in the collection of such [foreign] intelligence - it should have a monopoly on all operational work. This would ensure that all such activity comes within the regime of review and accountubility which will accompany the CSIS (emphasis added). ${ }^{\text {in }}$

This thesis extends the logic of Senator Pitfield's work by creating a system that feautures a statutory footing for the whole intelligence system, a senior Minister of National Security, consistent external review by a standing Parliamentary Committee and a National Security Review Committee, informed public debate as well as ongoing internal review by an Inspector General. As a result, acountability would be strengthened well beyond current circumstances. In addition, the potential for an intelligence monolith would be checked through significant expenditure reduction, by approximately 30 to 40 percent of current levels.

The contagion argument against consolidation is spurious in relation to the proposals in this thesis. Canada's foreign intelligence capability, similar to the existing one for security intelligence, would be limited to gathering information and intelligence, conducting analysis and informing and advising government. Statute would be explicit that Canadian intelligence would not have authority to conduct 'covert action' or 'active measures' to attempt to influence the activities of persons, organizations, or 
governments. Foreign intelligence activity would also be subjected to stricter ministerial, judicial and executive control than is now the case. Given these qualifiers. there is less risk that amalgamation would cause a negative contagion effect. The model proposed by this thesis would strengthen centralization by bringing security and foreign intelligence closer together, but it would stop short of 'complete' merger. The security intelligence and foreign intelligence sectors of the Department of National Security would each be headed by an Assistant Deputy Minister, both of whom would be responsible to the Minister and the Deputy Minister. The aim of this approach is to encourage harmonization of intelligence purposes, processes and priorities under a comprehensive and consistent legal, parliamentary and executive accountability regime.

In theory and in practice, the objectives, processes and products of security intelligence and foreign intelligence activity are increasingly less distinct. Security intelligence inquiries are motivated to preserve and protect the national security interest by collecting information and intelligence on threats to national security. Action tends to be triggered by the existence of reasonable grounds to suspect that certain activities may constitute a threat to national security. By contrast, foreign intelligence inquiries need not involve a threat per se. Foreign intelligence may be motivated to promote the national interest which may be broader than the national security interest. A foreign intelligence inquiry may be initiated in pursuit of positive information or intelligence for the purpose of providing advantage to decision makers. For example, 
in 1985 a Foreign Affairs representative requested, on behalf of Secretary of State Joe Clark, CSE to gather economic intelligence in support of a Canadian company that was bidding on a pipeline to be built in India for $\$ 2.5$ billion. ${ }^{105}$

Certain myths need to be exposed to demonstrate that security and foreign intelligence are increasingly less distinct. Security intelligence investigations are not necessarily conducted within Canada and foreign intelligence investigations need not be conducted abroad. CSIS legitimately conducts security intelligence investigations abroad and its foreign intelligence collection activities are limited to within Canada. CSE has conducted foreign intelligence collection activities within Canada, for example, at the "Kilderkin" site across from the Russian embassy in Ottawa. ${ }^{106}$ Indeed, the objectives of security and foreign intelligence may be identical. A foreign intelligence service may be used to collect information about threats to the national security of Canada that originate abroad. Dr. Peter H. Russell, constitutional law expert and former research director for the McDonald Commission, described this purpose as being a valid reason for establishing a Canadian foreign intelligence service.

On Course hinted at two underlying public policy issues in this area. The first issue concerns whether there is a distinction between the product provided by security intelligence and foreign intelligence organizations. Second, at issue is process and 
demand separate services for security intelligence and foreign intelligence activity.

The Government's report addressed these issues by stating:

Foreign intelligence refers to information or intelligence concerning the capabilities, intentions or activities of foreign states, corporations, or persons. It may include information of a political, economic. military, scientific, or social nature, and can produce information with security implications (emphasis added). ${ }^{107}$

The Report provided a simplistic discussion of these issues, appearing to contradict itself by adhering to the theory that the subject matter of security and foreign intelligence continued to be distinct thereby demanding separate organizations:

It is also worth noting the! the objectives of a foreign intelligence service are fundamentally different 'iom those of a domestic security service. While the former seeks to learn o' the capabilities and intentions of foreign states, the latter is more narrowly focussed on domestic counter-intelligence and counterterrorism objectives. ${ }^{\text {IH }}$

However, what Canadian domestic security service would not be interested in state sponsored terrorism directed against Canada or Canada's interests? Given the need for a broader definition of national security and the globalization of issues in the post Cold War era, government needs a new organizational approach to both complement and encourage new directions, partnerships and processes for intelligence. A close linkage between security and foreign intelligence is key to providing effective and accountable intelligence to government at least cost in the national interest. 
Similar to the United States, Britain, Australia, France and Germany, Canada observes a division, although not pure, between foreign and security intelligence activities and organizations. This practice contrasts to many intelligence sectors, especially those maintained in the Third World. ${ }^{109}$ In Canada, the division of labour in the intelligence sector appears increasingly untenable given the comparatively small size of the Canadian intelligence sector, fiscal pressures and the potential to increase efficiency, effectiveness and accountability through integration.

A key reason for consolidating security and foreign intelligence within a new Department of National Security is the need to carefully manage the relationship between the intelligence assessments function and foreign intelligence activity with the mandate of the Department of Foreign Affairs. Intelligence assessments are critical to the effectiveness of Canada's foreign affairs program. In principle, however, the role of practicing diplomats is incompatible with spying. Perhaps most Ambassadors tend to be "very reluctant to have intelligence operations being conducted from under their feet." ${ }^{\text {190 }}$ Notwithstanding a need for a strong intelligence capacity, it would be a mistake to locate a covert intelligence organization within Canada's Department of Foreign Affairs. Canada has no tradition comparable to the British experience where foreign intelligence has been closely associated with the foreign affairs program. Canada would be misguided to adopt the UK model in the absence of a supportive 
political culture. Although the scope of this thesis does not include military intelligence, the intelligence links between the Departments of National Security and National Defence would raise key issues that would have to be addressed.

A departmental business plan for national security and intelligence is needed to confirm and clarify the strategic direction, priorities, roles and expenditures for Canada's security and intelligence program. A business plan should encourage the integrated management of policy and program renewal, and financial, human, technological and capital resources and implications of strategic directions. A climate of continuous change, shifting priorities and unforeseeable operational pressures places a premium on long-range planning and the management of change. However, "strategic planning" that is "run like the Soviet economy with emphasis on central plans"191 " is a remarkably effective way of killing creativity and entrepreneurship at the extremities of the organization." Although planning is important for organizational success, Henry Mintzberg has cautioned that "too much planning may lead us to chaos, but so too would too little, and more directly." Strategic planning is currently ineffective in the intelligence sector as a result of compartmentalization and consequently there is a need to integrate the process of priority setting and strategy formulation in order to benefit from new ideas and creativity.

Strong organizational cultures within Canada's existing intelligence organizations tend to impede effective strategic planning on a cross-sector basis. Consolidation of the 
intelligence sector's components would open up new potential for a fresh planning process fueled by the cross-fertilization of ideas and knowledge. The plan should confirm and clarify the core program functions, values, and strategic directions of the Department of National Security. The plan would focus on key strategic issues such as partnerships, risk management, intelligence analysis, clients, foreign intelligence and organizational development. The Departmental plan would help support broader government objectives. The plan should emphasize macro resource management and the re-allocation of resources between functions to manage change and renewal. The plan should constitute a platform for periodic reporting, within the executive cadre, to central agencies and externally to Parliament and the public and to Departmental staff, regarding strategic objectives and performance indicators. ${ }^{192}$

\section{Inspector General for National Security}

Executive accountability for security and intelligence activity is key to the effective management of the intelligence program. The creation of an Inspector General for National Security, modelled on the current office and position of the Inspector General of the Canadian Security Intelligence Service, would help to strengthen executive accountability. The Inspector General would report to the Deputy Minister of National Security and would cooperate with the proposed National Security Review Committee by conducting reviews on behalf of the Committee. As the "Minister's eyes and ears" on the activities of the Department of National Security, the Inspector General would 
have a key role in ensuring that the operational activities of Canada's security and foreign intelligence services complied with the law and established polices. The Inspector General's presence would help prevent the occurrence of abuse of extraordinary powers that would be available to the new intelligence organization. In the event of such an abuse, the Inspector General's advice would support the Deputy Minister's decisions regarding redress or reform as part of an continually selfcorrecting system.

\section{Strntesic Framework: Ertectiveness}

The effectiveness of Canada's intelligence activity could be a key to the success of Canadian statecraft in the 21 st century. Canada's approach and commitment to the world is the subject of intense scrutiny in the context of increasing fiscal pressure, domestic political pressure over unity issues, major policy reviews and the government wide program review. Whatever Canada's choice regarding ends, the debate over means is no less important. Canada may continue to use a multilateral approach or it may shift in some areas toward greater unilateralism or leadership in the international arena. These choices could serve as indicators regarding government's level of expectations for intelligence support. Few operations abroad can be conducted without at least some form of assistance - be it intelligence, economic, military, or diplomatic support. Canada will be forced to adopt a range of strategies, from self-reliance to partnerships, to support its national interests. The globalization of issues underlines 
the utility of having strong and well integrated security and foreign intelligence capabilities. The effectiveness of Canada's intelligence efforts will depend on how well they are targeted. Key decisions will be required on how much government activity is needed, to what ends, and at what cost in six areas: partnerships, spying on friends, foreign intelligence, economic intelligence, intelligence support to law enforcement and strategic intelligence. These key issues are addressed below.

\section{Partnerships}

Partnerships, both domestic and international, are needed to maximize the benefits to Canada from scarce resources. The goal of partnerships in the Department of National Security should be to lever advantage for the Department or to respect the jurisdiction of others, while also benefitting the other. All partnerships, domestic, international, intergovernmental and non-governmental, should be designed to be "win-win", as in the long term, the Department may lack the resources to 'pay' for partners and may have to encourage the establishment of them around shared goals. Partnerships could be clustered around critical areas, such as intelligence assessments and production, service and risk management, operations, policy development, economic development, law enforcement, technology development, training and administration. ${ }^{193}$

Purtnerships should be considered a key strategic management issue for Canadian intelligence. Partnerships must be strengthened and formalized. The instruments for 
effective and accountable partnerships include Memoranda of Understanding (MOU:) with federal and provincial levels of government and liaison agreements with foreign nation-states and international organizations. At present, domestic relationships between Canadian intelligence organizations and other government departments and agencies are frequently unguided by MOUs. CSIS has a large number of domestic liaison arrangements with other federal departments and several provincial governments, except Ontario. The Communications Security Establishment only has MOUs with CSIS and Foreign Affairs although it has many other federal department 'clients.' The former Deputy Secretary, Security and Intelligence, of the Privy Council Office, Ward Elcock (now director of CSIS) advised the Parliamentary Sub-Committee on National Security that the fact there are relatively few CSE MOUs "really has no relationship to the ability of CSE to provide its product to those [other] organizations." ${ }^{194}$ The salutary affect of MOUs for managing and addressing important matters, however, should not be overlooked as demonstrated by other examples.

The 1989 MOU between CSIS and the RCMP "has resulted in a noticeable improvement in the exchange of information and intelligence between CSIS and the RCMP. "195 The MOU could support efforts to mitigate potential tensions forecast by then Inspector General Ms. Ursula Menke as likely to stem in the future from overlapping areas of jurisdiction and activity between CSIS and the RCMP. ${ }^{1 \%}$ Also on the positive side, an arrangement between CSIS and the Department of Citizenship and Immigration appears to have provided a context for the identification of issues, 
clarification of roles and responsibilities, and implementation of process changes to improve performance in controlling individuals who apply to visit or immigrate to Canada. ${ }^{197}$ The Canadian Armed Forces' increasing role in support of the efforts of other federal agencies and departments to control international drug smuggling, illegal migration, and new sources of terrorism ${ }^{198}$ should be guided by a series of MOUs confirming and clarifying objectives, roles and responsibilities. However, it is unclear from available sources of public information whether such MOUs have been developed or implemented.

With the end of the Cold War, many questions have been raised about whether old alliances among Western nation-states will crumble or be superseded by new arrangements now that the former primary adversary is no longer a strategic threat. In general, current arrangements, bilateral and multilateral, are based on former East-West relations and the military blocs that supported them. Mutual aims and a common perception of threats largely disappeared with the end of the Cold War. Such changes are likely to generate a greater need for political and economic intelligence for national purposes.

Canada may have to assume greater self-reliance for its own intelligence collection and analysis needs. In a changing world, many of Canada's emerging requirements are specific to Canadian national interests. Other nation-states are unlikely to address all of the issues important to Canada; allied or friendly nation-states will not always share 
the results of their efforts regardless of whether or not foreign interests coincide with Canada's requirements. On the other hand, the Canadian intelligence sector will be forced to readjust to the post-Cold War world without an increase in resources. Intelligence budgets are likely to decrease substantially at least over the next three years. In part, intelligence should be able to address the dilemma created by shrinking resources and growing, or at least non-traditional demands, by increasing both the number and the scope of intelligence liaison arrangements with other nation-states. ${ }^{199}$

Intelligence practitioners and scholars such as Wirtz, Doron, Westerfield, Finn, and Farson have shown that intelligence liaison and collaboration is no panacea. Intelligence partnerships entail perils as well as opportunities. A careful review of the trade-offs involved in Canada's intelligence liaison arrangements with foreign nationstates and international institutions is integral to the proposed renewal plan for Canada's intelligence capabilities and requirements. Information about relations between intelligence services is among the more sensitive issues in the intelligence profession. A major underlying reason for this is the fact that intelligence liaison tends to be viewed as a "source and method" that intelligence services have traditionally tried to protect from unauthorized disclosure. Sources and methods of intelligence continue to be protected in Canada much as they were during the Cold War. These include four specific areas. First, Canadian intelligence services continue to protect the identity of their human sources. Second, the location and details of intelligence installations are also protected from disclosure. Third, the capabilities of 
technical intelligence collection systems or devices, and investigative techniques are protected. Finally, Canadian intelligence will continue to try to protect the existence, nature and scope of cooperative relationships with foreign security and intelligence organizations that provide Canada with information and intelligence.

The term "liaison" covers a wide range of types and degrees of collaboration, across international borders, between intelligence services governmental and nongovernmental. First, full-fledged or full-service liaison arrangements are formal, intergovernmental authorized arrangements between the intelligence services of two or more nation-states. These are the most intimate type of arrangements typically covering the complete intelligence cycle, including: ${ }^{200}$

- an agreed system of security classifications, codewords, and procedures for protecting the security and confidentiality of generally wide-spread cooperation;

exchange of special designated liaison officers posted to the embassies, High Commissions or Trade Consulates in major cities of cooperating countries, and responsible for physically handling the exchange of intellizence and materials, for ensuring that agreed procedures are properly implemented, and for reporting back to their own headquarters on the operational requirements and practices of their host agencies; 
- intelligence exchange in relation to the full mandate of the respective intelligence organizations;

- formal contacts and close relationships at all levels of the organizations for the purposes of exchanging views on intelligence management, planning, training or technical issues; and

: joint operations or co-management of important facilitics.

The class provided for close intelligence cooperation among the United States, Britain, Canada, Australia, and, to a lesser extent, New Zealand after its policy on nuclear armed ships in its waters. Second, intelligence liaison arrangements are formally or informally intergovernmental approved wqderstandings for the purpose of intelligence exchange. ?. $)$ Given the varying mandates of different intelligence organizations, the exchange of intelligence may relate to all or part of the mandates of the respective intelligence organizations. Third, another form of liaison which is governmentally approved either formally, informally or on a one-time or ad hoc basis, involves intelligence support. This form of collaboration includes the provision of supplies and/or training and/or advice, from one intelligence service to another, across international borders. Members of Canada's intelligence sector, including the Canadian Security Intelligence 
Service, like the intelligence services of other NATO members, are now developing cooperative liaison with intelligence services from the emerging democracies of Central and Eastern Europe. According to CSIS' 1993 Public Annual Report:

These relations are especially useful in ascertaining the extent to which former adversaries worked against our interests, and are providing channels through which to exchange information on issues of common concern, such as terrorism. They also provide a vehicle with which to assist these countries in situating their security and intelligence organizations within a democratic framework. ${ }^{201}$

Liaison in the business of intelligence has been a constant consideration in many assessments of Canada's intelligence capacity and requirements over the years. The debate reflects two dominant factors, first, the international dimension and origins of many of the threats to and opportunities for Canada's national security interests. Secondly, Canada, unlike ithst of its "friends" or "allies", has not developed a foreign intelligence service. ${ }^{202}$ A considerable body of literature about intelligence sharing, much of it historical, illustrates that intelligence liaison and cooperation is an important part of modern intelligence activity. ${ }^{203}$

Liaison is especially important for Canada. Past studies, including the McDonald Commission, have concluded that Canada was indeed getting its inoney's worth, even "a bargain", 204 from its multilateral intelligence arrangements. Canada probably continues to reap great benefits from its intelligence liaison arrangements. As of March 31, 1994, CSIS had a total of 194 liaison arrangements with 119 countries and 
three international organizations. ${ }^{205}$ The possibility that dramatic changes in the international environment may threaten Canada's continued access to allied intelligence has led Canada to initiate a special effort to encourage greater allied participation in the Canadian assessment process by reintroducing a practice, discontinued some years ago, of inviting them to certain Intelligence Advisory Committee meetings at the Security and Intelligence Secretariat of the Privy Council Office. ${ }^{206}$

Liaison is a core feature of the complete "intelligence cycle" model. Liaison has no fixed location on this cycle because it is a mode of activity at every point in the cycle. ${ }^{207}$ Indeed, incelligence liaison has provided Canada with a coping mechanism that has perpetuated the situation in which Canada could continually muddle along with some strengths in certain areas of intelligence and persistent weaknesses in others (notably foreign intelligence). As one of the most important resources available to Canadian intelligence, intelligence liaison arrangements need to be strengthened to maximizt the benefit to Canada. Liaison is generally based on reciprocity. In future, Canada will increasingly have to provide valuable intelligerice to allies in order to receive intelligence of comparable value in exchange. Efforts to improve intelligence liaison will inevitably involve trade-offs which must be made on the basis of a careful assessment of the costs and bencitits in the national interest. If national security is a shared responsibility, the challenge for Canada then is io find the optimal balance for "intelligence burden-sharing." 
Intelligence in general is a "cooperative and competitive, multi-faceted coalition-game of many degrees of closeness and alignment. ${ }^{1209}$ Cooperation is usually not just a simple duel between sets of nation-states. Alliances of power tend to shift with the issues of the day and, since the end of the Cold War, a new level of complexity has emerged for intelligence organizations. Intelligence relationships can become a form of "crypto-diplomacy"210 where intelligence relationships function as a supplement to conventional diplomatic relations, or even as a substitute for them.

The case of intelligence substituting diplomacy is straightforward. When diplomatic relations or publicly acknowledged contacts have been severed, nation-states or organizations may attempt to establish contacts secretly. The classic case of this strategy is Israel, in the long period when it has been pariah to many communist and Third World countries. Behind the scenes there has actually been "quiet" diplomacy (much of it through intelligence channels), publicly disavowed of course by all parties. ${ }^{211}$ This approach also permits Israel to use crypto-diplomacy as a complement to traditional diplomacy when dealing with nation-states such as the United States ${ }^{212}$ and Canada. ${ }^{213}$ A classic example of crypto-diplomacy as a supplement (loosely called "back-channels") is the Cuban missile crisis Krushchev - J.F. Kennedy linkage via non-official-cover KGB officer Georgi Bolshakov and Robert Kennedy. The Kennedys were well aware that they were dealing via the KGB. 
Crypto-diplomacy partly via liaison is employed among major powers to complement their open diplomatic relations. One objective can be to "test the waters" for new proposals, through channels that can fairly easily be disavowed if unproductive. Another objective may be to convey a message that is true but thought to be less believable if communicated through conventional diplomacy. Such circumstances might arise where intelligence channels are more directly linked to the recipients' key decision-makers than are diplomatic channels or where the intelligence channel seems faster and more reliable. ${ }^{214}$ In certain instances, the intent of one side may be to substantially deceive the other, in which case similar tactical considerations would be involved.

The "regular" or "back" channel alternatives will be assessed differently if the sender believes that it has recruited the recipient's diplomat or intelligence officer. A classic example of the latter is the "evil empire" escalation of East-West tension when United States President Ronald Reagan and British Prime Minister Margaret Thatcher were briefed on the intentions of Mikhail Gorbachev by Oleg Gordievsky, the KGB double agent who worked for British intelligence and helped to transform Western perceptions of the Soviet regime. ${ }^{215}$

Regular diplomatic channels and intelligence back channels are sometimes difficult to distinguish. Many intelligence officers operate under official cover pretending to be diplomats. However, even the intelligence officers who are "undeclared" to the 
intelligence services of the host country can become well-known for their real line of employment, sometimes relatively easily. ${ }^{216}$ Yet sometimes the ambiguity may be advantageous. ${ }^{217}$ It may be useful for both sides simultaneously to know but for both sides to be pretending naivete. The bottom line is that the availability of ambiguous back and regular channels can at least muddy the waters of diplomacy and of intelligence. Availability of such channels is not always a net advantage to those who have and use it.

A number of risks are intrinsic to intelligence partnerships and liaison. First, an intelligence service risks direct and indirect recruitment of its personnel, namely the people conducting the liaison or information provided that suggests other. for recruitment elsewhere. Standard intelligence folklore has it that the primary purpose of all liaison was penetration. Second, intelligence liaison risks manipulation by the other side, procedurally and substantively. Third, information provided may get "recycled" back. This process may :ause an exaggerated level of confidence in the validity of certain information or force one to change views if a falsehood already passed is resurfaced as if derived from another independent source. This latter phenomenon is known as "blow back" in intelligence jargon. Third, intelligence liaison risks loss of control of information, despite the third party rule which prohibits passing information to a third party without consent of the originator. Fourth, liaison 
risks compromise of sources and methods used to obtain information, also despite the third party rule. Finally, intelligence liaison arrangements risk possible future disclosure of the fact or content of collaboration, leading to political embarrassment.

Methods to manage the intrinsic risks include negotiating rules for cooperation. including agreed decisions concerning basic factors such as whether liaison contact is formal, informal, continuous or intermittent, whether the arrangement is bilateral or multilateral, some mutual understanding relative to the dominance of one side relative to the other(s), the scope of the arrangement, specific limitations and explicit or implicit methods for enforcing the arrangement.

Given these considerations, is intelligence as a whole (i.e., process, product and organization) seamlessly entwined with diplomacy? Is it seamlessly entwined with military preparedness (or warfare)? Is there any truly essential difference between intelligence and diplomacy or between intelligence and military preparedness (or warfare)? Is intelligence not so much "soft war" as "tough diplomacy"? Answers to these questions will vary from nation-state to nation-state and help shape the intelligence capability and its appropriate position within government.

Diplomacy is traditionally defined as comprising "negotiation," "representation," and "reporting" (with the operational priorities normally in that order). Intelligence, however, also involves these characteristics, with the priorities altered to place 
reporting first, negotiation second, and representation last. ${ }^{218}$ Arguably, the core of secretiveness that is reflected in the downplaying of the role in representation for intelligence is an essential differentiating feature from diplomacy. On the other hand, intelligence could be seen as meshed essentially with military preparedness or warfare and be differentiated with diplomacy on that basis. But such a definition would be time-bound, and especially inappropriate for re-positioning intelligence in the post Cold War world. Professor Adda Bozeman and others have concluded that "conflict will no doubt remain he paramount theme for non-Western societies (and perhaps virtually all of them) in the 21 st century - whether conflict is described as "political," "economic," "unconventional," "secret," "cold or hot war," or low intensity conflict." Conflict will, however, be more variegated than it was in the past. In a sense, the crisis of the international states system has deepened in the last decades, particularly in the aftermath of the Cold War. Ethnically and culturally discreet components of the nation-state increasingly seek secession and independence or engage in revolution as the number of non-nation-state decision makers increases. This trend includes statetranscending multi-national businesses, religious factions (e.g., the Shi'ite complex), and terrorist networks. ${ }^{219}$

Continuing to identify intelligence essentially with war and preparations for war is increasingly narrow-minded, even anachronistic. But, democracies continue to compete with one another, they have secrets to keep from one another and, sometimes, from parts of their own populations. Various parts of their population sympathize with 
these needs of secrecy. Furthermore, non-democracies remain and there may be future relapses from democracy. As a result, the perceived need for capabilities for secret statecraft seems likely to persist, even if major-power war does not.

A three-way differentiation for diplomacy, intelligence and military preparedness (or warfare) may be conceived in a largely democratic world ${ }^{220}$ in the following manner. First, the model would highlight at one end of a spectrum the widening openness of diplomacy, and also its inhibitions about intrusive activity. Second, the model would associate gradations of secret diplomatic-type activity more with intelligence and covert action and locate the core of these activities in a middle position entailing the secret dimension of statecraft. Third, the model would allow the middle set to shade (conceptually) over into military preparedness, peacekeeping and war, at the opposite end of the spectrum from open diplomacy.

Conceptually, such a model would need to be adapted to serve Canada. A broad category of national security information, part secret sourced and part open sourced, should constitute the platform for a Canadian model. In addition to diplomacy and military preparedness, the model for Canada should include protective security and security enforcement dimensions although these functions need not be performed by the Departmnent of National Security. This model would signal to intelligence practitioners how vulnerable their core "middle" activity is to being absorbed into the work of either open diplomacy or the preoccupations of the "peacetime" military or 
law enforcement or economics or many other disciplines. This continuum also emphasizes the fact that intelligence, quite simply, is an important, albeit limited function which depends on partnerships, governmental and non-governmental. Finally, this continuum reflects the fact that Canadian intelligence behaviour and structure can be expected to exhibit features of diplomacy, given that it relies particularly heavily on partnerships and liaison.

\section{Spying on Friends}

As established international alignments of the past half-century become increasingly unhinged and reformulated, the role of intelligence in backstopping diplomacy and strengthening liaison will be important although increasingly problematic. The Government of Canada will increasingly need to understand and manage a complex range of risk trade-offs associated with the challenging questions of whether, how, and how much to spy on "allied" or "friendly" nation-states and whether, how and how much to react when allies or friends are caught spying on Canada.

There are now many examples of multi-sided intelligence liaison and spying involving "friendly" nation-states. We know for example that Canada has installed and used Communications Security Establishment "embassy-collection" operations arouna the world for most of the last twenty years. ${ }^{221}$ One of Canada's intercept capabilities, which is or was allegedly stationed in the Canadian Embassy in New Delhi, was 
apparently used to monitor not only the communications of Sikh extremists but also to respond to the Minister of External Affairs' direction to collect economic intelligence:

The Minister would like you to look into some economic intelligence.... We have a Canadian company bidding on a pipeline to be built in India for $\$ 2.5$ billion, and we'd like to get as much information on what's going on as possible. ${ }^{222}$

In another alleged case, the Communications Security Establishment intercepted a speech to be given to the United Nations by a foreign official, days before it happened. Information was relayed to Ottawa and directly to the Canadian representative at the United Nations, former Ontario New Democratic Party leader Stephen Lewis, which he used to rebut the speech. ${ }^{223}$

Other examples suggest that liaising with and spying on "friendly" nation-states is not uncommon. United States intelligence was tracking South Africa's own nuclear weapons program, which former President Frederick de Klerk explained was climaxing in the mid-1980s with the production of six Hiroshima-size nuclear bombs - intended, according to South Africa officials, to be able in an emergency to blackmail the United States with the message: "We need you to send the Marines [to help us, or we'll have to nuke $\mathrm{X}$ in Africa]."224 Accordingly, the following equation of liaison and espionage has emerged: 
- the United States was liaising with but also spying on South Africa;

- the United States was liaising with but also spying on Israel:

- Israel was liaising with but also spying on the United States;

- Israel was liaising with South Africa; and

- Israeli liaison with the United States did not include assistance for the United States in American efforts to spy on South African nuclear development, probably because Israeli collaboration with South Africa included reciprocally promoting the nuclear weapons development of the two countries. ${ }^{225}$

If such ambiguities are the norm in international relations, now more than before, how prepared is Canadian intelligence to play this game? How prepared is Canada to acknowledge playing it? Mike Frost is. This twenty-five year veteran of Canadian signals intelligence has recently publicized previously classified information, ${ }^{226}$ which if true, could lead to public outrage. Frost declared:

I have come to believe that the people have a right to know what is really going on wt.en it comes to the Canadian government and international espionage. We can no longer hide our heads in the sand and pretend that we are bystanders, not part of the game. ${ }^{227}$ 
There is no doubt that intelligence should remain a relatively secret dimension of Canadian statecraft, a tool of coalition diplomacy and of the national interest. Striking a balance among these requirements will, however, be increasingly difficult. In future, if coalitions themselves become increasingly unstable, there may be increased incentives for the government to task intelligence to assess the viability or health of the coalitions in which Canada is involved. One may legitimately doubt whether the Canadian government and the intelligence sector are prepared for such a mission. Will the Canadian public ever be ready to relate this? Clearly, the public will never be sympathetic or supportive if its primary opportunity to learn about the existence of Canada's intelligence capabilities as well as its features, limitations and risks is an intelligence failure. A strunger national consensus on the purpose of Canadian intelligence is key to a relatively self-sufficient and autonomous intelligence capacity that is poised to serve Canada's national interests.

Risk management associated with spying on allied or friendly nation-states must address the following questions: whether to do it; how to do it; which nation-states to do it against, and why. The latter two questions are most sensitive. The most sensitive concerns about "which allied or friendly nation-states" relate, of course, to the UKUSA partners. Perhaps the most sensitive "why" rnncerns are about economic competition intelligence. Interestingly, economic security intelligence, or the intelligence concerning the protection of one's own national economic assets from theft by the intelligence organizations of foreign nation-states, seems more readily 
acceptable. Perhaps eventually that will evolve into broader acceptance among Canadians of positive economic competition intelligence, given the intimate and increasing links between intelligence and counterintelligence, generally. ${ }^{228}$

The case of one nation-state which spies on an allied or friendly nation-state may be difficult for some analysts to accept. Yet such acts could well be rational. The selection of intelligence targets involves utility calculations of cost-benefit trade-offs bounded by certain parameters, and by considerations deduced from possible mutual national interests, political embarrassment being just one, and perhaps a very marginal one, in a complex set of interests. ${ }^{229}$ In the Jonathan Pollard case the employment of a spy by the Israelis against their American friends was a rational act from the point of view of the kind of information sought (benefits) so long as the potential costs (political embarrassment) and the probability of its implementation fall within prescribed parameters. ${ }^{230}$

Post-Cold War national security requirements are potentially ambiguous. Everyone is partly a competitor of everyone else, and to that degree properly an intelligence target, yet no one is always an enemy or always a proper target. Competition is cooperative, and cooperation is competitive. In sum, the intelligence model proposed for Canada is focused on supporting decision making for Canadian statecraft that includes diplomacy 
on a continuum from openness to secrecy; and intelligence partnerships and liaison should be scrutinized as the important function it is, positioned in the middle of a continuum between open diplomacy and military preparedness.

\section{Foreign Intelligence}

The notion that Canada should have a foreign intelligence service is not new. No consensus exists in Canada on whether Canada should establish its own intelligence agency loosely akin to the American Central Intelligence Agency (CIA), the British Secret Intelligence Service (BSIS), the Australian Secret Intelligence Service (ASIS) or the Israeli Central Institute for Intelligence and Special Duties (MOSSAD). In Canada, there scems to be a consensus that Canada does not need a foreign intelligence service mandated to undertake covert action to influence foreign governments or the politics of foreign nation-states. Rather, the debate centres on whether Canada would benefit from the creation of an intelligence organization mandated to covertly collect secret information that government could otherwise not obtain. John Starnes has opposed the creation of such a service in Canada because he has not been persuaded of Canada's need or political, bureaucratic or professional ability to maintain such a capacity. In 1987, John Starnes noted, however, that to his personal knowledge, in the last thirty years there have been a half-dozen such proposals made to Canada by representatives of various allied and friendly nation-states. ${ }^{231}$ 
More recently, In Flux But Not In Crisis addressed this question and suggested the need for further study. In response, the Government indicated that it haci been reviewing Canada's foreign intelligence program:

Canada's own foreign intelligence collection resources, coupled with existing intelligence-sharing arrangements with allies, meet national foreign intelligence requirements. But if the international environment evolves to the point where existing arrangements can no longer fully meet national requirements, the Government will have to assess carefully what alternative arrangements might be needed. ${ }^{232}$

The issue has been a "recurrent but muted theme" of the intelligence debate in this country for more than forty years. ${ }^{233}$ Since the international environment has changed so much, the time is right to revisit this issue to see whether a Canadian foreign intelligence service could help Canada adapt to and prosper in this changing environment. ${ }^{234}$ In answering this question, this thesis considers three primary factors. First, Canada's current foreign intelligence capabilities are assessed. Second, an assessment explains why existing capabilities are inadequate to meet Government's needs. Third, an assessment explains the potential social and fiscal cost-benefit tradeoffs that may be associated with establishing a Canadian foreign intelligence service.

Canada's current foreign intelligence collection capabilities, including both overt and covert capacities, are as follows: 
- overt diplomatic collection and reporting from abroad;

- covert signals intelligence collection by the Communications Security Establishment within Canada and abroad;

- covert collection assistance by the Canadian Security Intelligence Service under section 16 of the CSIS Act, within Canada;

- $\quad$ "spin-off" foreign intelligence from section 12 CSIS Act security intelligence collection activity;

- $\quad$ security and intelligence liaison officers stationed abroad:

- overt/covert collection and reporting by military personnel abroad;

- overt collection and reporting through other departments with personnel stationed abroad, such as Citizenship and Immigration's Immigration Control Officers;

- overt/covert collection by the Royal Canadian Mounted Police abroad; and

- information and intelligence sharing arrangements. 
Given this varied capacity, exactly what requirements could not be met through existing resources? There are a number of reasons for establishing a new capacity. First, the end of the Cold War meant the end of a high degree of common threat perception, common purpose and common priorities among "old" allies. Although it is unlikely that all of Canada's current intelligence sharing arrangements will be discontinued, the new environment and the need to prepare and implement new directions in Canadian public policy in the fields of immigration, foreign affairs, trade and peacekeeping, among others, suggests that Canada will need to be more self-reliant to meet increasingly distinct information and intelligence requirements tied to its own national interests.

Second, the rapid pace of change in society requires new approaches and new capacities to acquire reliable information and quickly use knowledge to make decisions with confidence at the governmental level. Third, information and intelligence that may be critical to Canada concerning political, economic, social and military matters may not be given to, or shared with Canada, even by its closest allies. Fourth, the lack of such a foreign intelligence capacity perpetuates, and perhaps increases, Canada's dependence on other nation-states' foreign intelligence. Over time, this may well threaten Canadian independence. ${ }^{235}$ Finally, the probable expansion in the scope of intelligence activity by foreign nation-states, including friends and allies, is increasingly likely to affect Canada's interests. In foreign affairs, trade and economic matters, in a nation-state to nation-state context, there may be no friends, only 
competitors at best and enemies at worst. Canada will need to equip itself not only to counter such activities but to collect information in support of its own requirements. The best way for Canada to obtain advantage is to know in advance what our competitors intend to do, how, when, and by what means. ${ }^{236}$ Canada has a comparative advantage from which to build a professional foreign intelligence service. Canada's multicultural make-up offers a large pool of skilled potential recruits with language proficiencies, professional attributes and cultural awareness to support foreign intelligence activity.

Detractors advise against the creation of a Canadian foreign intelligence service for a number of reasons. Perhaps the greatest reservation stems from fear that the potential for political embarrassment to Canada caused by an intelligence failure outweighs any possible benefits a foreign intelligence agency could provide. Second, apart from potential political or social costs, the fiscal cost associated with creating a new government organization is considered prohibitive in a period of fiscal restraint. Third, Canadi is said to lack the requisite professional expertise to implement and sustain a successful foreign intelligence organization. Fourth, considerable doubt exists as to the political, bureaucratic and, perhaps, public will to establish a foreign intelligence agency. The Government would be foolish to try to establish such an organization secretly and there is little likelihood that the Government would initiate a Parliamentary debate on the issue unless forced to do so by public outrage. 
On the other hand, there will never be a time that is more "right" than now to undertake such a debate. The security and intelligence system needs to be overhauled in the aftermath of the Cold War. All of the issues concerning national security and intelligence could be addressed in the Program Review context. Full consideration of the need for a Canadian foreign intelligence service should be a key driver of the renewal plan for Canadian intelligence. This thesis proposes the establishment of a relatively small, highly focussed, human intelligence capacity to collect by covert means abroad information and intelligence in support of Canada's national interests. A "limited secret intelligence service", ${ }^{237}$ modest in size and scope that is devoted exclusively to intelligence gathering, would not be an innocent matter. To collect any intelligence by covert means in a friendly or hostile foreign environment would not necessarily be inexpensive, uncontroversial or uncomplicated. A prior condition for each mission would be a careful assessment of the potential costs and benefits to Canada. Those calculations would vary depending on urgency, perceived importance of the intelligence sought, potential for political controversy, political and bureaucratic will, fiscal cost, alternative sources of information or methods of collection, the social and political environment of the target nation-state, and the potential for harm to the safety of Canada's intelligence officer(s) tasked with operating abrocd.

The costs and benefits associated with establishing a Canadian Foreign Intelligence Service could be optimized provided that a number of key requirements were met. In other words, the benefit to Canada should be high at the lowest possible cost to the 
tax-payer. To paraphrase a public statement made by Pierre Marion, whose career included separate terms as head of France's domestic and foreign intelligence services, any foreign intelligence service worth its weight would pay for itself many times over in a single successful operation. ${ }^{23 \mathrm{~b}}$ The first prerequisite is that the intelligence service would have to be established by statute following full Parliamentary debate and public consultation. Public input would be key to setting appropriate trade-offs on the role of the agency within the context of Canada's position in the world and its enduring values of justice, tolerance and compassion. Second, the service would only be mandated to collect, to the extent justified in the national interest, by covert means, information and intelligence vital to the national interests of Canada. Third, the service's mandate would expressly exclude authority to conduct "covert action." The service would be banned from undertaking paramilitary or military operations, political intervention intended to influence other nation-states, organizations or persons or from conducting attacks upon foreign leaders or other persons. Fourth, the foreign intelligence service would be subject to review by a Parliamentary Standing Committee on National Security, Cabinet, the Ministerial of National Security, the National Security Review Committee and the Deputy Minister of National Security. The Minister and the Deputy Minister would develop the business plan for the national security program as a means to conduct a continual review of the program. Other means, such as the judicial process for warrant approval, the Inspector General of National Security and periodic reviews of the foreign intelligence program by the Auditor General would provide the capability to monitor and ensure both effectiveness 
and accountability. Finally, both the political and bureaucratic levels would focus increasingly on raising the level of public debate to enhance the role and influence of Canadians as key stakeholders in the evolution and delivery of Canada's foreign intelligence program.

\section{Economic Intelligence}

Economic intelligence is one of the "hot" public policy issues involving intelligence in the post Cold War era. Globalization and change in the international system of nationstates are increasing governments' efforts to protect and promote their respective international economic comparative advantages. Canadian prosperity depends on a modern economy which is increasingly integrated into a prosperous global economy. ${ }^{239}$ In the new, knowledge-based global economy, Canada is experiencing difficulty maintaining its position ariong the major economic powers. In research and development, productivity and innovation, Canada has fallen behind its competitors, and human resource development has been slow to produce necessary skills to drive the renewal of Canada's economy.

To what extent should Canada use or develop its intelligence capability to protect economic security and gather economic intelligence in the pursuit of national interests? Policies on trade, job creation and economic growth, the environment and development assistance relate directly to our security or well-being. But they are sufficiently 
distinct to warrant specific treatment rather than lumping them in the national security basket. $^{240}$ Are Canada's economic intelligence efforts anchored by a sufficiently developed theoretical underpinning linking and, where appropriate, also drawing distinctions between, the objectives of economic security and national security? Should we be concerned about how far Canadian intelligence goes in the pursuit of economic intelligence? What nation-states, companies or individuals are most actively involved in collecting economic intelligence through covert means against Canada's interests? What is the end use of such intelligence and what has been its impact on Canadian national security? More importantly, what will be the impact of this problem into the 21 st century?

In the public mind, intelligence has been synonymous with military and political intelligence. But economic intelligence, including industrial, commercial, scientific and technological intelligence, has always played a role in the intelligence world. History is replete with examples of the importance of economic intelligence in the cuntext of national security. During the Cold War, so long as Communism was associated, economic, scientific and technological threats were perceived in traditional national security terms. The instructions Moses gave to his spies about Canaan predominantly concerned economic information, such as the quality of land. ${ }^{241}$ The travellers who went to China in the Middle Ages to study the silk industry's secrets 
were engaging in technology transfer. ${ }^{242}$ British intelligence in the 1930 s fully understood that the production lines of the German aircraft industry were a matter of the highest priority. ${ }^{243}$

In general terms, "the relationship between intelligence and economic matters depends on the extent to which a nation-state sees its economic situation and relationships in national security terms. ${ }^{\text {"244 }}$ In a command economy system, intelligence would be concerned with the economic aspects of the government's relations with foreign governments, just as it is with all other aspects of its international relations. In such systems, viewing economics in national security terms many be almost axiomatic. ${ }^{245}$

In a market economy, however, it is much less clearer which economic issues have national security dimensions that justify or require the involvement of intelligence. In a democratic society, economic policy is much more likely to be determined by the interplay of domestic and international economic interests than by a coherent view (whether or not based on intelligence) of the future world economic environment. For this reason at least, it is not clear whether the government in such a society would be an important consumer of economic intelligence. Private economic interests could probably put it to greater use, but it is not clear that intelligence gathered by the government expense would be distributed to individuals or corporations to further private interests. ${ }^{240}$ 
The external or internal environment may be an overarching factor that determines whether government views economics in national security terms. The answer may differ in wartime or in the course of peacetime international negotiations on economic matters. Where the domestic environment is characterized by a regime with an "industrial policy" government may have a greater appetite for economic intelligence on industrial, commercial and financial activity in other nation-states. ${ }^{247}$ Proponents of greater intelligence involvement in economics tend to argue that econouisics should be a major priority for intelligence organizations in the 1990s and beyond. Advocates of this role include Ray Protti, the former Director of CSIS, and the former United States Director of Central Intelligence, Stansfield Turner. Mr. Turner has asked rhetorically:

If economic strength should now be recognized as a vital romponent of national security, parallel with military power, why should America be concerned about stealing and employing economic secrets? ${ }^{245}$

The opponents of an increasing economic dimension to intelligence activity reject the premise that international economic competition inherently poses a threat to national security. They argue that such an assumption is unwarranted because it betrays a fundamental misunderstanding of economics and would detract increasingly scarce intelligence resources from their proper function. Strategic analyst Stanley Kober has suggested that engendering fear of wide-spread economic espionage is an attempt to fill a threat vacuum caused by the collapse of the Cold War, for parochial reasons. ${ }^{244}$ 
One should be careful about "laying down formulae"250 to prescribe an economic intelligence role for the proposed Department of National Security. The policy or program instrument chosen to deal with specific economic interests will be more effective if the decisions are made in the context of a strategic framework that focuses intelligence activity and distinguishes economic security from national security. The framework will clarify to what extent the government and the public are prepared to provide information and intelligence to private Canadian firms. To what extent should such support, which is a form of subsidy, be a legitimate role for the intelligence and rational security sector? That decision will guide the extent to which Canada should become involved in economic espionage or intelligence collection. Governmental intelligence could possibly be applied to business practice in at least three areas. First, intelligence gathering data for risk analysis, competitor intelligence or security. Second, intelligence data analysis for integration into strategic planning, or for monitoring business activity. Third, operations and information security to protect proprietary information, personnel and property from competitors or adversaries. ${ }^{251}$ Traditionally, intelligence practices that might have been used by governments to support private interprises - espionage or secret operations, for exampie - have been considered illegal by Canadian standards or at least unethical or unnecessary. Nonetheless, in other nation-states, such practices are often the norm. By contrast, such practices may be the norm in Japan (which may be establishing a foreign intelligence service to collect economic intelligence), France, South Korea, Russia, Britain and the United States, among others. These nation-states consider the use of 
their national intelligence services to gather and analyze information on behalf of their business firms to be a matter of national security and easily justifiable. ${ }^{252}$ It would. therefore, seem to be prudent for Canada to define national security more in economic terms than it has in the past if it is to survive and prosper in the $\mathbf{2 1 s t}$ century.

\section{Intelligence Support to Law Enforcement}

The time is right to revisit the overlapping roles of intelligence and law enforcement in Canada. The creation of the Canadian Security Intelligence Service reflected important distinctions between the roles of security intelligence and law enforcement. The RCMP's mandate is to investigate individuals who may be engaging in criminal activity, whereas the CSIS mandate is to investigate and analyze security threats. These different mandates neither define nor reflect mutually exclusive areas of jurisdiction. In particular, the domain of counter terrorism and other forms of political extremism with violent overtones, such as right-wing or aboriginal extremism, have and will continue to require careful management attention in Canada. In the post Cold War world, jurisdictional demarcation lines are being increasingly blurred. This means that government can achieve effectiveness, accountability and affordability by drawing clearer distinctions and setting firmer priorities. Otherwise, government will face public outrage as a result of poorly managed challenges, whether strategic, operational or analytical, that increasingly streddle the mandates of intelligence and law enforcement agencies. 
The primary areas for consideration are right-wing extremism, aboriginal extremism, and international organized crime. At the moment, none of these problems thrcatens the core values, national security or sovereignty of Canada. The organized crime threat in Canada, while serious enough, is not of the same magnitude experienced in either Italy or Columbia where drug lords exert de facto control over governance. Canada's right-wing extremist problem cannot be equated with Gerniany's where the rise of the fascist right might be threatening the security of the nation-state and the safety of many citizens. Government intervention in the name of national security should be proportional to the level and imminence of the threat and weighed against the benefits of managing the risks inherent in those threats. Canada's problems in these three areas require real partnership approaches. These problems cannot always be addressed adequately by law enforcement agencies and the criminal justice system. Well defined cooperation that respects the mandates of organizations is needed. Primary responsibility for managing the public safety problems identified above should involve shared authority among the RCMP, the proposed Department of National Security, the Department of Citizenship and Immigration and others. To confirm and clarify roles and responsibilities, the proposed new Canadian National Security Act would distinguish between 'politically motivated violence' and 'serious politically motivated violence.' The distinction would help to ensure that politically motivated, extremist-type activity with violent overtones does not 'automatically' become the subject of investigation by the nation-state's security intelligence apparatus. Rather, Canada's approach would be a collective one that pools proper skills and knowledge 
from across departments and sectors to develop appropriate intervention strategies in the national interest. Intelligence activity has a high potential to damage the civil liber:ies of Canadians or persons resident in Canada. Part of Cabinet's role, then. should be to rationalize the mandates and set the strategic frameworks for the organizations whose mandates intersect and overlap in relation to the above problems. The resource allocation implications of Cabinet's decisions might be significant given the apparent current level of activity by CSIs in these areas. ${ }^{253}$ Heads of the national police, security and foreign intelligence organizations, respectively, would need to continue to monitor the level of these problem areas to ensure that new arrangements continued to be appropriate to the circumstances.

The role of foreign intelligence in support of law enforcement in the above areas could be fairly extensive. The foreign intelligence service could gather intelligence abroad on the key players, networks, supply routes and foreign government involvement in international organized crime that other government organizations could not obtain. Such intelligence could be useful in judicial proceedings and for law enforcement operations against such criminal activity in Canada. A foreign intelligence organization would have unique access to intelligence from allied or friendly foreign intelligence agencies. Finally, a foreign intelligence service would also possess specialized skills and resources that law enforcement or security intelligence agencies could not be expected to have. 
Cabinet would establish a strategic framework to guide all intelligence activity in support of the government's broader agenda, including law enforcement. In the latter case, Cabinet would establish categories of cases where prosecutions would be pursued. Cabinet would not usually be involved in providing case specific direction. This limitation is consistent with the proper administration of the law in the Canadian federal system. Cabinet would provide strategic direction to ensure that administrative or statutory changes were developed and implemented to provide for the effective use of intelligence in judicial proceedings. This area was the focus of attention in both In Flux But Not In Crisis and On Course: National Security for the 1990s. At the time of publication of On Course, the Government indicated that a Department of Justice special working group was studying the sensitive and difficult issue of how to balance the nation-state's interest in effective security intelligence collection over the long-term and its interest in effective prosecution of particular security offenses, consistent with the need to protect individual rights. ${ }^{254}$ The Government informed the public that it would be considering a "number of options for putting mechanisms in place, whether statute or policy-based, to ensure that a proper balance is maintained in a consistent manner."25s To date, however, there has been no public announcement or follow-up to clarify whether this issue has been addressed or remains unresolved. Under the proposed new arrangement for intelligence in Canada, the use of intelligence in judicial proceedings would be critical. Both security and foreign intelligence is needed in judicial proceedings and the implications of this fact wou'd need to be assessed, 
especially because this area offers government an opportunity to demonstrate openness. new thinking and the net value and relevance of intelligence expenditures in the national interest. ${ }^{256}$

Strategic Intelligence for Canadian Statecraft

Reliable, relevant, timely and strategic information and intelligence is key to decision making and long-range planning at the government level. The past decade has witnessed several attempts to identify weaknesses in, and improve, Canada's strategic intelligence capability. Useful strategic intelligence to support Canada's national interests has been elusive as reflected in numerous studies over the years. Prominent among those studies are the McDonald Commission of Inquiry in the late 1970s, then Clerk of the Privy Council, Gordon Osbaldeston's report entitled Foreign Intelligence For Canada, ${ }^{257}$ Senator Michael Pitfield's Report on Bill-C157, Arthur Kroeger's 1984 report entitled Management of the Canadian Foreign Intelligence Program, ${ }^{258}$ Gordon Osbaldeston's People and Process in Transition based on a review of the Canadian Security Intelligence Service in 1987, the Special Senate Committee's Terrorism and the Public Safety in 1987 and the Second Senate Special Committee's Terrorism and the Public Safety in 1989, Owen Davey's An Idea of National Intelligence of 1989, 259 the Special Parliamentary Committee's five year review of the CSIS Act and the Security Offenses Act entitled In Flux But Not In Crisis and the Government's On Course: National Security for the 1990s. 
In 1993, increasing dissatisfaction with the intelligence product produced under the guidance of the Privy Council Office Intelligence Advisory Committee and at Foreign Affairs peaked. The intelligence product was generally unsatisfactory in terms of the volume of paper produced, the layers of approval required, the timeliness in relaying the product to consumers, and getting it to the right person. In response, just prior to the 1993 federal election, Foreign Affairs' Foreign Assessment Bureau was disbanded and a new central Intelligence Assessment Secretariat was established within the Privy Council Office. ${ }^{260}$ The new assessments group has been tasked to:

- coordinate the production of central assessments;

- draft assessments on foreign, political and economic issues previously prepared by Foreign Affairs;

- develop government-wide positions on issues;

- improve intelligence dissemination; and

- tailor intelligence product to the needs of individuals, particularly the Prime Minister and Cabinet, and departmental policy sections. ${ }^{261}$ 
Weakness or failure of one part of the intelligence system jeopardizes the effectiveness of the whole intelligence system. Consequently, any effort to strengthen the centralized intelligence assessments function should involve an assessment of the implications for the complete intelligence sector and intelligence cycle, namely the priority setting processes, collection, analysis and reporting. Any attempt to fix one area without consideration of the implications for the rest of the intelligence sector and of government risks failure and possible disaster.

The proposal made by this thesis is to establish a specialized group of no more than thirty intelligence analysts, with strong strategic thinking skills, within the proposed Department of National Security. The group would be headed by an Assistant Deputy Minister who would report to the Deputy Mirister. The Assistant Deputy would chair an Intelligence Assessments Steering Committee whose members would include the Assistant Deputy Ministers, Security Intelligence Sector and Foreign Intelligence Sector of the proposed Department of National Security and the key Assistant Deputy Ministers of partner and consumer or client departments. The intelligence assessment group would have close connections through the Department's Deputy Minister and the Assistant Deputy Minister, Strategic Assessments, with the Prime Minister, the Cabinet and senior executives of other federal departments, other levels of government both domestic and foreign and with the non-government sector. 
The strategic intelligence assessment group would be challenged to address specific key issues. First, it would improve Canada's capabilities in the fields of political, economic, social, cultural and inter-disciplinary analysis. Canadian interests will be affected significantly during the remainder of the 1990 s and beyond by the degree to which democratization succeeds or fails in the societies currently trying to shed dictatorships and centrally planned economies. Identifying how democratization may fail and how failure can be prevented or mitigated will require new forms of political and social analysis that intelligence could pioneer. This area represents an opportunity for the intelligence sector to provide value added for decision makers. With the changing environment, Canada's existing intelligence analysts may lack a basic knowledge of new players and new adversaries in the fields of politics, sociology, religion, culture, military industries and the state of technology and science in foreign nation-states. Without a comprehensive and reliable assessment of these aspects of the nation-states of strategic interest to Canada, no assurance exists that political, cultural or economic developments can be gauged. ${ }^{262}$ The government's intelligence sector should have an appropriately resourced assessments capability which supplies decision makers with necessary background information or foreknowledge of the activities and intentions of leadership in nation-states of strategic interest to Canada. A value added intelligence analysis function would benefit the government in any number of areas, from securing foreign markets to exporting Canadian resources and products, to maximizing the benefits to Canada through international arrangements, to monitoring compliance with those international agreements, to assessing the intentions of foreign 
nation-states involved in a dispute with Canada, to assessing the challenges facing Canadian peacekeepers abroad, and so on. Strategic intelligence should enable government to derive maximum benefit at least cost from its environment in the national interest.

Second, organizing Canada's intelligence assessment capacity to support Canadian statecraft is less a budgetary problem than a conceptual challenge. In a fundamental sense, the primary role for strategic intelligence analysts is to meet the demands of intelligence users. What is collected and how it is provided must be determined by the needs of the user. For intelligence to reap significant benefits, its primary users should be the Cabinet and the most senior decision makers in the Public Service. Such intelligence users, or direct clients, need flexible, accessible and responsive service. Taxpayers, or indirect beneficiaries, on the other hand, are concerned with the deficit and growing debt. They increasingly demand that Government spend less overall to reduce the tax burden. The Canadian public is demanding greater assurances that their tax dollars are being spent wisely and with probity. Establishing an intelligence assessment group within the proposed Department of National Security would aim to ensure that authority, responsibility and the purpose for strategic intelligence assessments is clear and statutorily based in order to lend support for expenditures and credibility. This approach will require strong leadership and partnerships with other government departments, especially the Departments of Foreign Affairs and National Defence. The government challenge will be to ensure sufficient collegiality for the 
new system to function as intended. A tri-partite partnership will mean that the Departments of National Security, Foreign Affairs and National Defence will all be consumers, contributors and co-producers of intelligence. The lead role for a great deal of the intelligence product will reside with the Department of National Security.

Third, the transformation of Canadian intelligence hinges on the extent to which relations can be improved between producers and consumers of intelligence.

The fact is that, over the years, the policy maker and the intelligence officer have consistently (and with frighteningly few exceptions) come together hugely ignorant of the realities and complexities of each other's worlds - process, technique, form and culture. ${ }^{203}$

Two prominent examples in the Canadian experience may be cited. The triangular relationship between the Canadian Security Intelligence Service, the Secretariat of the Solicitor General and the Security and Intelligence Secretariat of the Privy Council Office has, from time to time, exhibited inertia, confusion and lack of cooperation and shared strategic perspective. Second, in recent years, the relationship between the Privy Council Office and Foreign Affairs has also exhibited similar problems.

The proposal in this thesis would consolidate the secretariats for security and intelligence from the Solicitor General and the Privy Council Office under the Executive Director of Planning and Renewal within the Department of National Security. The Executive Director would report to the Deputy Minister and would be 
responsible for providing corporate strategic planning and advice functions and developing the departmental renewal agenda. The role of the Executive Director a small staff would be to act as catalysts for strategic change in support of the Deputy Minister's role and responsibilities for leadership, advice to the Minister, legislative and policy change at the governmental level, ${ }^{204}$ creation of the Department of National Security as well as integration of the security and foreign intelligence programs.

As Canadian intelligence adapts a more client-centred orientation, it will need to identify its primary clients. For the system to function as intended the primary clients will have to be Cabinet and senior executives. The Cabinet, the head of intelligence and other senior executives would establish annual intelligence requirements for Cabinet approval. The role of the Deputy Minister of National Security would focus in part on nurturing close advisory or professional relationships with the Prime Minister, Cabinet and senior decision makers in the bureaucracy and in the foreign intelligence organizations of allied nation-states. The Deputy Minister's challenge in managing the relationship between the policy maker and the intelligence producer is to ensure that intelligence does not become "politicized" or "cooked." In Canada, the phrase "policy relevant and policy neutral" is used to describe what intelligence should be. The search for an optimal relationship between decision makers and intelligence 
producers raises questions about whether intelligence can ultimately avoid being politicized. It also focusses on the degree to which policy makers (and their staffs) selectively use - or abuse - intelligence to persuade superiors, Cabinet or the public. ${ }^{265}$

In supporting decision makers, the role of an intelligence organization does not stop at policy development. Intelligence activity and product also supports the implementation and conduct of policy. There is a legitimate role for intelligence in monitoring policy with a view to informing government of its impact, whether intended or otherwise. If the intelligence effort identifies that policy has led to unintended consequences, it has an assumed obligation to advise decision makers and to provoke them to ask the right questicns. The intelligence product should ensure that the process of policy development and implementation is self correcting and renewing.

In sun?, the strategic intelligence group would have two primary roles. First, in response to Government direction, the assessments group must lead and share responsibility for the collection of information and intelligence. It should lead the analytical process, sometimes carrying out the analysis, sometimes coordinating it, and it must share responsibility for the proper distribution of the product to those who need it most. Special emphasis should be placed on the provision of relevant strategic assessments and raw intelligence to the Prime Minister, Cabinet, and senior bureaucrats. 
Second, a critical component of the intelligence group's role should be played out interdepartmentally, intergovernmentally and with partners in the non-government sector. The process of analysis and maintaining a network of experts is key to the success of the endeavour. Therefore, the group must be "plugged-in" to centres of expertise and knowledge to acquire the information that is dispersed throughout society and to develop the knowledge of decision makers so that it may be applied to maximum advantage for Canada. The dynamics of this set of relationships will influence the role and determine the effectiveness of the intelligence assessments group. Effectiveness will depend on whether the intelligence assessments are heeded, relevant and timely enough to be useful to decision makers. The compartmentalization of "finished" intelligence must be minimized and the product exposed to wide scrutiny. Increasing the number of people who have access to a "finished" intelligence product is analogous to subjecting a scholarly paper to the marketplace of ideas. ${ }^{2 \text { ton }}$ Such exposure may not always yield a better product, but it will increase the likelihood that flaws will be detected.

The intelligence assessment group will constitute an independent assessment function. It will be small and modelled loosely on the British model, nam :ly, the Joint Intelligence Committee (JIC) staff. The JIC staff is a small, independent group of analysts, led by the Joint Intelligence Committee which is chaired by a 'wise man' with influence based on the strength of the individual and the direct influence of the Prime Minister. Intelligence products are the sum of the best analysis the staff can 
produce. The product comes from a single group with no dissenting voice allowed.

This approach helps ensure that the product reflects not the lowest co amon denominator but torth-ight prcduct from independent analysts. JIC staff analysis is frequently better than anything produced by the $\mathrm{CIA}$, and yet American intelligence has thousands of analysts who do essentially the same job as the 20 strong JIC staff. ${ }^{267}$

JIC staff tend to produce more "current" intelligence than "strategic". ${ }^{268}$ The Canadian strategic intelligence group will focus on strategic intelligence product that is defined to include both short and long term assessments that are pivotal to the decision making around Canada's security and strategic interests. 


\section{CHAPTER 4. CONCLUSIONS}

It is becoming more and more obvious that the nation-states able to compete successfully in the next century will be those that can encourage the development and application of new knowledge, that are quick to identify and exploit new opportunities around the globe and that can operate in a relatively stable political and economic environment at home. Canadian intelligence could play a key role in ensuring these prerequisites of success.

Periodic security and intelligence scandals in Canada, however, raise fundamental doubts about whether whether intelligence and covert operations have always been of little value at best and both morally and politically dangerous and economically expensive at worst. ${ }^{269}$ Certain allegations by "insiders" may be overstated, but their critical statements ${ }^{270}$ should be examined to determine if they hold any water at all and to establish whether intelligence activity has been seriously discredited. Rigorous analysis has often curfaced genuine, serious problems in the midst of dramatic allegations. Resolving this set of issues is essential to the future credibility of intelligence activity in Canada.

Efforts to transform Canadian intelligence must address certain key and basic requirements. First, the costs of intelligence (social, moral, political and fiscal) must be controlled. In part, meeting this accountability requirement means that all 
intelligence activity must be focussed on clear, firm priorities. Second, the emphasis of intelligence activity must be on analysis and advice in support of vital national interests, rather than on investigations and operations for their own sake. Third, as Canada ventures into the 21 st century global community through its foreign affairs, trade and peacekeeping efforts, it will need accurate strategic intelligence assessments of the intentions of "target" nation-states or persons in order to realize Canadian objectives.

The Canadian system of government is founded on the values of justice, tolerance and humanitarianism. These values ought to guide whatever intelligence capability the Government of Canada decides it requires. Canada has always had an intelligence capability. True, it was not such that it could prevent all disasters, including the June 1985 bombing of Air India Flight 182 which killed all 329 people on board, most of whom were Canadians, ${ }^{271}$ but there is no intelligence operation that could have or can guarantee complete protection or zero risk. There are, quite simply, limits to what intelligence can do. In this as in so many fields, the responsibility of the Government of Canada and of Canadians is to work together to establish and accept those limitations.

Canada must refocus its expenditures and emphasis associated with security and intelligence activity. The program must be dedicated to advancing, in a very focussed way, Canada's national interests. Increasingly, intelligence efforts must provide 
government with real advantage in the pursuit of its strategic interests by divining the intentions of foreign nation-states, organizations or persons through assessments of their actions and communications. Regular Cabinet direction is needed to keep intelligence relevant. Cabinet must specify which security and intelligence action is required to help cnsure Canada's public safety and economic security, the integrity of Canadz's democratic process, the security of government assets, and international peace and security. Canadian intelligence's genuinely unique contribution should be providing decision makers with value added, timely information, knowledge and advice. The intelligence function, however, is not a panacea. So, it is incumbent for security and intelligence practitioners to explain its limitations to its political masters. Adopting a more unified approached, reducing overall expenditures and reallocating resources from the rationalized or discontinued programs will improve Canadian intelligence. Greater openness and comprehensive statutory and accountability mechanisms based on agreed principles are necessary, but will not preclude mistakes. Intelligence activity will listen to some of the wrong conversations, anger allies and even infringe unfairly upon the rights of Canadian citizens from time to time. For these, the system will provide mechanisms for redress to the fullest extent reasonable. In such a system, transgressions will be "regrettable rather than repugnant blunders"272 and Canadian intelligence will be, and will be perceived, as effective, responsive, affordable and accountable. Canada itself will be the honourable federation we want it to be. 


\section{SUMMARY OF RECOMMENDATIONS}

\section{Primary Recommendations}

The following recommendations are fundamental components of the proposed transformation of Canadian intelligence.

1. Place Canada's entire intelligence system on a statutory footing, entitled the Canadian National Security Act, incorporating and modifying the Canadian Security Intelligence Service Act, the Security Offenses Act, the Official Secrets $A c t$ and ensuring all legislative provisions necessary for implementing the recommendations set out by this thesis. The Act would:

- define "intelligence" and "national security";

- $\quad$ provide mandate, roles and responsibilities;

- $\quad$ provide an accountability framework;

- $\quad$ establish an integrated str' :4ure for intelligence; and

- establish mechanisms for review and redress.

2. Establish a Department of National Security to consolidate and strengthen existing or new security intelligence and foreign intelligence components. The new Department should be headed by a senior minister of the Crown to be 
known as the Minister of National Security. The Department would be created by consolidating and renewing the following:

a) from the Ministry of the Solicitor General - the Canadian Security Intelligence Service, the National Security Directorate of the Solicitor General Secretariat, the Office of the Inspector General of the Canadian Security Intelligence Service and part of the Royal Canadian Mounted Police's National Intelligence Directorate as well as its security screening resources;

b) from the Privy Council Office - the Security and Intelligence Secretariat and the position of the Security and Intelligence Coordinator;

c) from the Department of National Defence - the Communications Security Establishment, most of National Defence's security screening resources and part of its strategic intelligence analysis capacity; and

d) from the Departments of Foreign Affairs, Industry and Trade; Citizenship and Immigration; National Revenue (Customs); Transport; and Industry - part of their strategic policy and/or intelligence analysis capacities, respectively. 
In comparison with existing structures for security and intelligence activity in Canada, overall the Department of National Security would be smaller, flatter, leaner and more strategic, integrated and versatile. It would have the following management and accountability structure:

- Deputy Minister, under the direction of the Minister of National Security, has responsibility for the control and management of the all programs and activities conducted by the Department of National Security;

- Assistant Deputy Minister, Foreign Intelligence Sector, accountable to the Deputy Minister for the control and management of foreign intelligence operations conducted by a sector comprised of the Commi aications Security Establishment and a new Canadian Foreign Intelligence Service;

- $\quad$ Assistant Deputy Minister, Strategic Assessments and Corporate Services Sector, accountable to the Deputy Minister for the control, management and provision of strategic intelligence assessments and corporate services conducted by a sector comprised of the Security and Intelligence Secretariat of the Privy Council Office, the National Security Directorate of the Solicito: General Secretariat and the Finance, Administration, Information Technology, Human Resources and operational support se.vices from all of the components used to create the new Department; 
- Assistant Deputy Minister, Security Intelligence Sector, accountable to the Deputy Minister for the control and management of security intelligence activities conducted by a sector comprised of the Canadian Security Intelligence Service and Security Screening Services consisting of all resources previously dedicated to security screening from the Canadian Security Intelligence Service, Department of National Defence and the Royal Canadian Mounted Police;

- Executive Director, Planning and Renewal, responsible to the Deputy Minister for strategic planning, advice and integration of the new Department and its sectors; and

- Inspector General, in accordance with the statutory mandate of the Inspector General provided by the Canadian National Security Act, responsible to the Deputy Minister for reviewing the operational activities and monitoring compliance by the Department with the law and operational policies.

3. Create a Canadian Foreign Intelligence Service to strengthen Canada's foreign intelligence collection capacity. Establish within the new Department a relatively small and specialized service (about 200 full time equivalents) for the purpose of covert human intelligence collection abroad in support of government's vital national interests. 
4. Focus Canada's national security policy and program on Canada's vital national interests based on public consultation and through stronger links to government's broader economic, social, foreign affairs and trade objectives.

5. Reduce by 30 to 10 per cent of overall expenditures for Camadian intelligence during 1995-1998 in recognition of a shift from counter-espionage priorities and as a means to clarify strategic priorities, to inform policy and program renewal decisions and to make appropriate strategic trade-offs in the national interest.

6. Strengthen Executive accountability for Canadian intelligence activity by formalizing a committee structure to support decision making. First, establish the senior position of Minister of National Security. Second, ensure that full Cabinet, chaired by the Prime Minister, is the decision-making body for establishing Canada's strategic national security priorities and directions. This approach will be feasible provided that Cabinet remains relatively small, approximately 20 members. If Cabinet grows, then consideration should be given to establishing a Cabinet Committee on National Security. Third, create a Deputy Minister for National Security responsible for overall management and leadership of the national security program and a Deputy Minister level Committee on National Security to support decision making by Cabinet. the Minister of National Security and the Deputy Minister of National Security. 
The Committee of Deputy Ministers should be chaired by the Deputy Minister of National Security, with membership consisting of the Assistant Deputy Minister, Security Intelligence Sector, Assistant Deputy Minister, Foreign Intelligence Sector, Assistant Deputy Minister, Strategic Assessments and the Deputy Ministers of Foreign Affairs, National Defence, Citizenship and Immigration, Justice, Industry, Solicitor General and the Commissioner of the Royal Canadian Mounted Police.

7. Strengthen Parliamentary and public accountability for Canadian intelligence activity by establishing a new Parliamentary Standing Committee on National Security responsible to oversee all of the security and intelligence activities of the Department of National Security and to report to the public on the effectiveness, accountability and expenditures related to Canadian intelligence activity conducted by the Department of National Security. This Committee would replace the Parliamentary Sub-Committee on National Security of the Standing Committee on Justice and the Solicitor General. 
8. Strengthen Parliamentary and public accountability for Canadian intelligence activity by replacing the Security Intelligence Review Committee with a new National Security Review Committee. The new Committee would have a mandate covering all of the security and intelligence activities of the Department of National Security and, therefore, of the entire security and intelligence sector excluding the military component. Members of the National Security Review Committee, a quasi-judicial body, would be appointed according to a process similar to that governing the appointment of new Supreme Court and Federal Court judges. The National Security Review Committee would aim to carry out an objective, non-partisan review of sensitive national security issues. The Committee's reporting requirements to the Minister of National Security and to the Parliamentary Committee on National Security would parallel the existing Security Intelligence Review Committee model.

9. Establish the provision of strategic intelligence vital to Canada's national interests and national security policy decision-making as the primary role of the Department of National Security and, therefore, of Canadian intelligence.

10. Strengthen Canada's strategic intelligence analysis capability by creating within the new Department a small, specialized strategic intelligence assessments group - well integrated with government and non-governmental 
organizations - to provide decision makers with ielevant and timely strategic intelligence vital to the national or national security interests of Canada. This capacity will be created by using key resources from. among other government departments and non-governmental institutions, both the Security and Intelligence Secretariat of the Privy Council Office and the National Security Directorate of the Solicitor General Secretariat. 


\section{Secondary Rexommendations}

The following secondary recommendations, not fully addressed by this thesis, would need to be carefully examined in order to implement the proposed transformation of Canadian intelligence.

11. Establish strategic intelligence priorities for the Government of Canada to guide collection, analysis, reporting and advice. Cabinet, based on the recommendations of the Minister of National Security, would be responsible for establishing strategic intelligence priorities for Canadian intelligence activity and resource allocation. The priorities setting exercise would include, as an integral component, consultation with clients, partners and stakeholders, including the Canadian public.

12. Strengthen Executive accountability for the management of Canadian intelligence by replacing the Office of the Inspector General of the Canadian Security Intelligence Service with the Office of the Inspector General of National Security, accountable to the Deputy Minister of National Security.

13. Strictly refocus the mandate of the Communications Security Establishment on government's renewed strategic intelligence priorities and by rationalizing the overlapping information security (INFOSEC) programs of the 
Commusications Security Establishment, the Royal Canadian Mounted Police and the Canadian Security Intelligence Service.

\section{Strictly refocus the mandate of the Canadian Security Intelligence Service on} government's renewed strategic intelligence priorities. Specifically:

- in order to better manage shared jurisdiction, rationalize the counter terrorism function performed by the Canadian Security Intelligence Service with the Royal Canadian Mounted Police. In this regard, counter terrorism priorities should be carefully reviewed, particularly right-wing extremist activity and international organized criminal activity in Canada. A key consideration in such a review should be whether or to what extent, if any, such issues are properly addressed as a threat to national security by the Canadian Security Intelligence Service, rather than as a law enforcement issue with national implications by the Royal Canadian Mounted Police. Real partnerships and the magnitude of the 'threat' should be central far:ors in this review which aims to clarify and confirm roles, responsibilities and resource allocation.

- rationalize the counter intelligence function performed by the Canadian Security Intelligence Service with other government departments and 

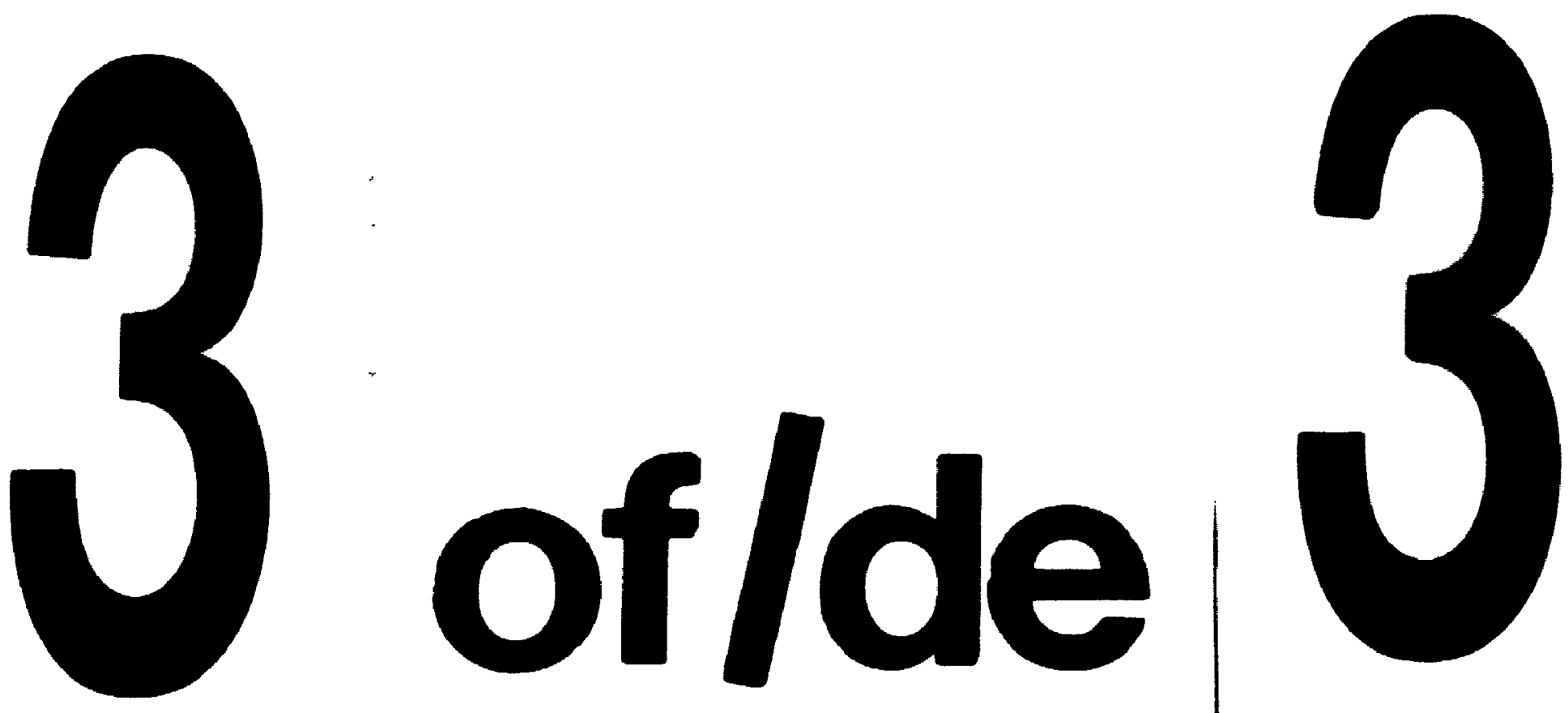

PM-1 3\%" $" \mathrm{X}$ " PHOTOCRAPHIC MICROCOPY TAAGET Mas 1010a AUESIISO "2 EQUIVALENT

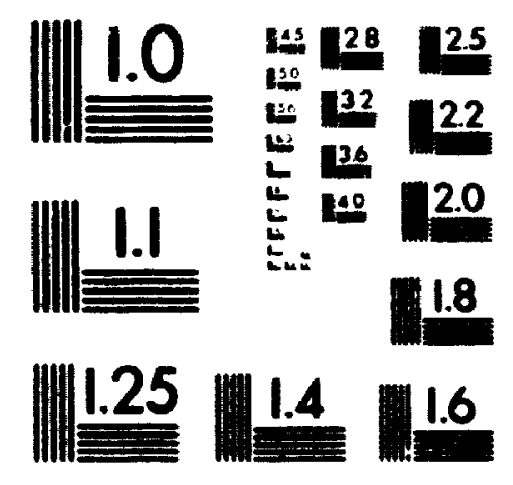

PAECISIONSM RESOLUTION TARCETS 
agencies. In this regard. reassess economic security activity to determine whether or to what extent. if any, national security is threatened by foreign government sponsored economic espionage or whether problems in this area are more appropriately dealt with by law enforcement, import-export controls, industry, or still other means.

15. Rationalize the Government Security Policy particularly as it relates to the security screening function performed by the Canadian Security Intelligence Service, the Royal Canadian Mounted Police, the Department of National Defence and Departmental Security Officers of Federal Government Departments. Significantly reduce the fiscal and social costs of the government security screening program by reducing the amount of information requiring classification and also the requirement for security clearances through a formal risk management strategy.

16. Consider ways and means to integrate and harmonzie military intelligence activity with the activity of the Department of National Security. Military intelligence will continue to be vital to Canadian statecraft. Key to the success of both military intelligence activity and security and intelligence activity of the Department of National Security will be an effective, strategic partnership between the two departments and a mechanism that provides a similar level of review envisioned for the activity of the Departement of National Security. 
17. Vigorously pursue efficiencies and economies by rationalizing and redesigning all core processes (c.g., intelligence collection, analysis and advisory roles, and security screening); reduce overhead and streamline policy and corporate services; and introduce new management approaches using client service standards and a formalized risk management framework. 


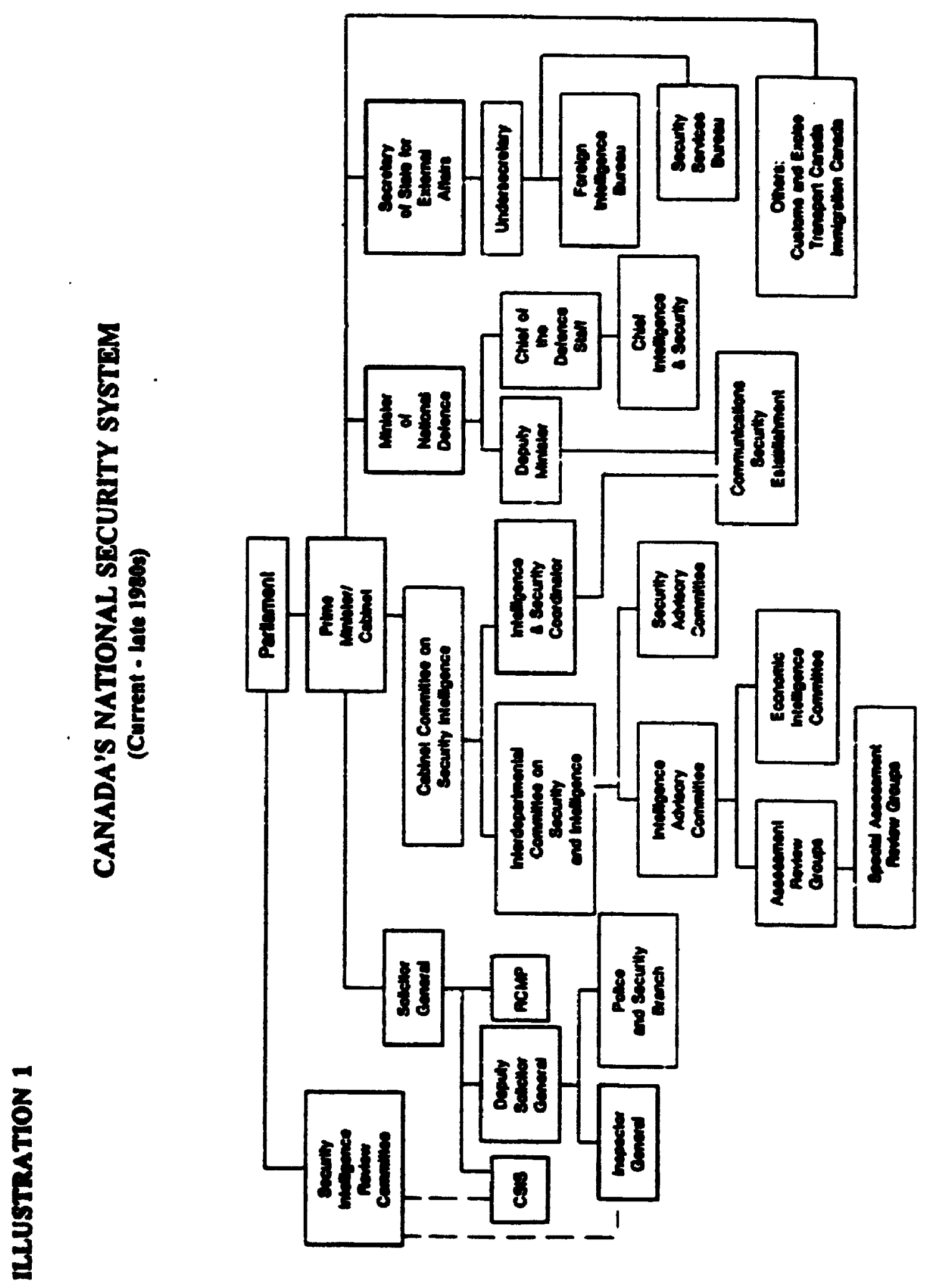

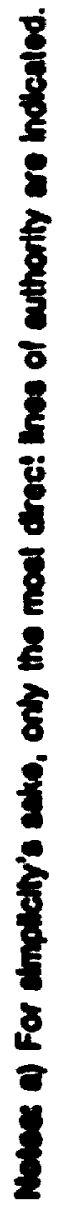




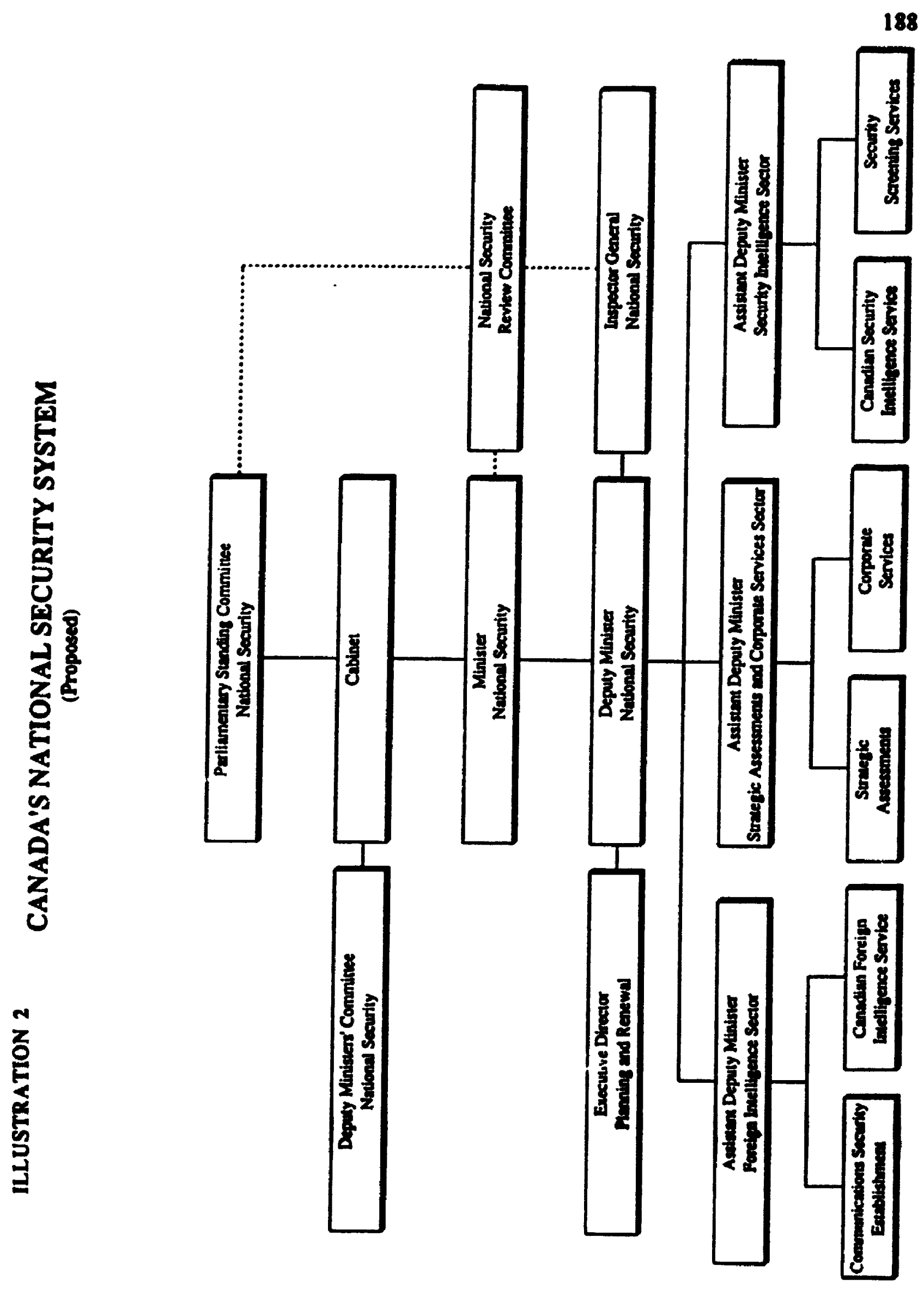




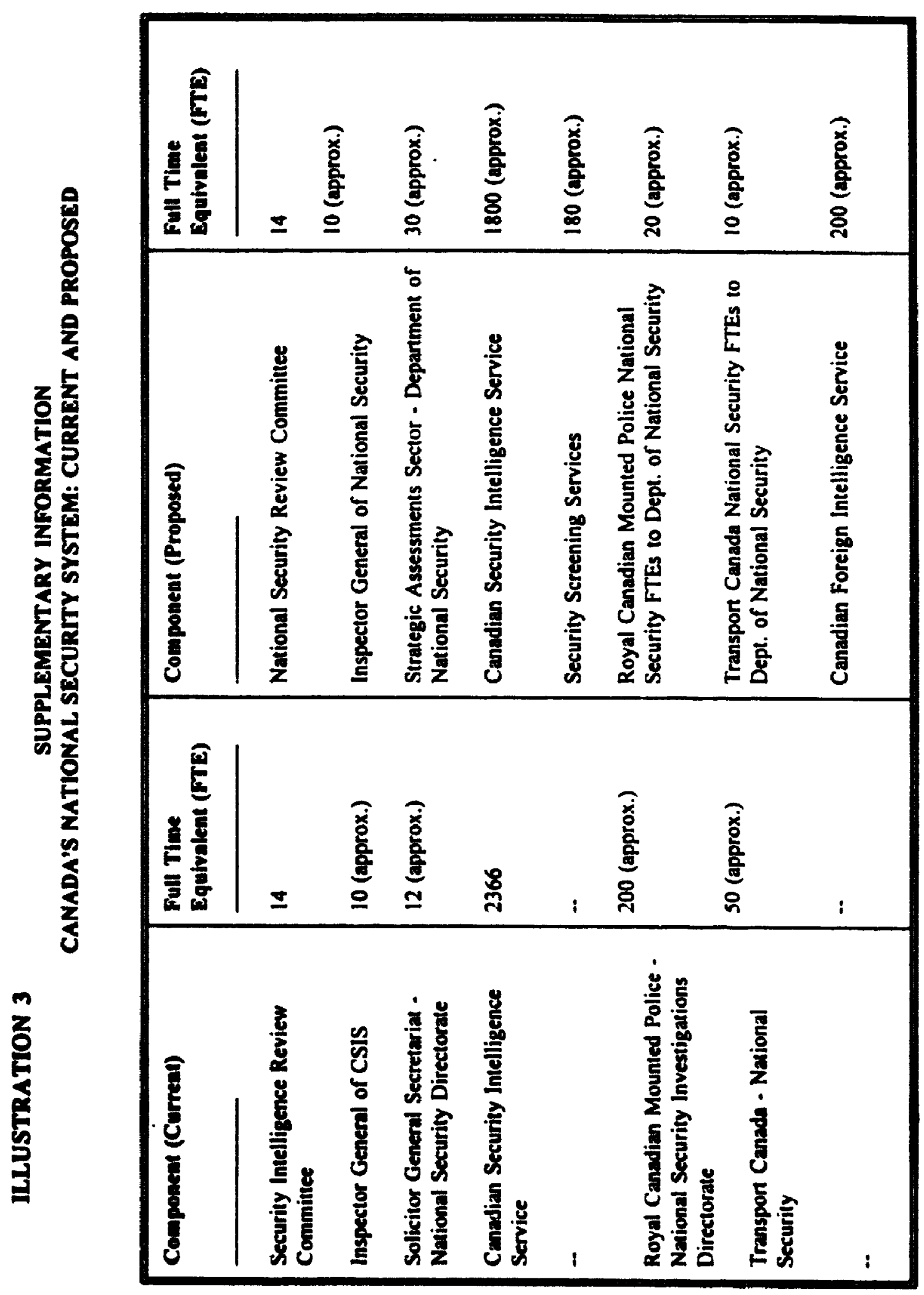




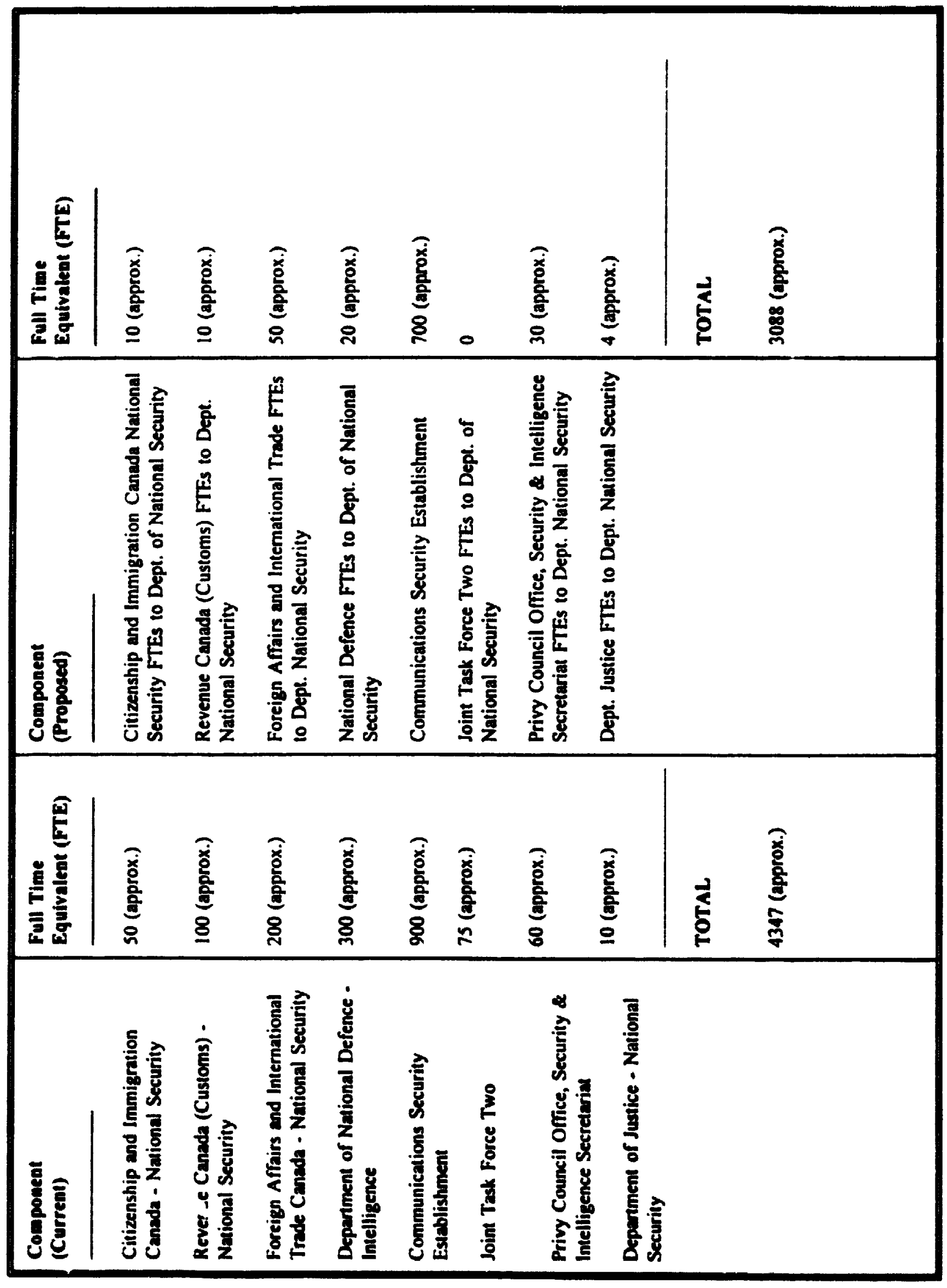




\section{ENDNOTES}

1. Canada's Foreign Policy: Principles and Priorities for the Fiunre, Report of the Special Joint Committee Reviewing Canadian Foreign Policy (Ottawa: Puhlic Works and Government Services Canada. 1994): 4.

2. Reg Whitaker. "The Politics of Security Intelligence Policy-Making in Canada. 1970-1990," (paper presented at a joint session of the Canadian Political Science Association and the Canadian Association for Security and Intelligence Studies at the Annual Conference of the Learned Societies, Victoria. B.C.. May 1990). 7.

3. Stuart Farson, "Accountable and Prepared? Reorganizing Canada's Intelligence Community for the 21 st Century," Canadian Foreign Policy 1:3 (1all 1993): 44.

4. Blair Seaborn, "Intelligence and Policy: What is Constant? What is Changing?" Commentary 45 (a Canadian Security Intelligence Service publication. June 1994): 2.

5. Ministerial direction from Solicitor General James Kelleher to Reid Morden, Director of the Canadian Security Intelligence Service on the Counter Subversion program, November 13, 1988.

6. Simon Dalby, "Security, Intelligence, the National Interest and the Global Environment," (paper presented at a conference organized by the Canadian $\Lambda$ ssociation for Security and Intelligence Studies on "Intelligence Analysis and Assessment: The Producer/Policy Maker Relationship in a Changing World," Ottawa, Ont.. October 1994): 2.

7. Privy Council Office 1994-95 Estimates, Part III Expenditure Plan (Ottawa: Minister of Supply and Services Canada. 1994): 13.

8. Interview, 1994.

9. This thesis uses the term 'sector' rather than 'community.' The latler term conveys a false sense of integration and cooperation among the various components of the government's intelligence capacity.

10. In Flux, But Not In Crisis, A Report of the House of Commons Special Committee on The Review of the Canadian Security Intelligence Service Act and the Security Offenses Act (Ottawa: Supply and Services Canada, 1990): 43.

11. Farson. "Accountable and Prepared?" 60.

12. Angelo Codevilla, Informing Sratecraft: Intelligence for a New (entury (New York: Free Press, 1992): xvii. 
13. Seaborn 6.

14. For example, the Security Intelligence Review Committee noted in its 1987-88 Annual Report that "the history of assessment units in Canadian security intelligence was a record of failed starts." (41).

15. Mike Frost and Michel Gratton, Spyworld: Inside the Canadian and American Intelligence Establishments (Toronto: Doubleday, 1994): 224-7.

16. Jean Jacques Blais, "The Political Accountability of Intelligence Agencies Canada," Intelligence and National Security 4:1 (January 1989): 108.

17. As one example, the author participated in the American Bar Association Standing Committee on Law and National Security Conference, "Intelligence In A Post Cold War World," Washington, D.C., April 1992.

18. Farson. "Accountable and Prepared?" 44. However, there are indications that the level of debate is increasing in Canada such as the Annual Public Statement in the House of Commons on National Security by the Solicitor General, at which time the Minister tables the Canadian Security Intelligence Service Public Report, the Security Intelligence Review Committee Annual Reports, annual conferences organized by the Canadian Association for Security and Intelligence Studies, occasional published articles on Canadian intelligence issues and a number of recent books on Canadian intelligence matters.

19. Use of the term 'community' in this instance is not intended to suggest a lack of rivalry among intelligence services in Britain.

20. The Heritage Front Affair, Report to the Solicitor General of Canada by the Security Intelligence Review Committee (Ottawa, 1994).

21. Frost and Gratton. Spyworld.

22. Freedom and Security Under the Law, Commission of Inquiry Concerning Certain Activities of the Royal Canadian Mounted Police, Second Report - Volume 1 (Ottawa: Minister of Supply and Services, 1991): 645.

23. In Flux 53. Bruce D. Berkowitz and Allan E. Goodman, Strategic Intelligence for American National Security (Princeton: Princeton University Press, 1989): 168-185.

24. Improving Social Security in Canada: A Discussion Paper (Ottawa: Human Resources Development Canada, 1994): 7-11.

25. Freedom and Security 642. 
26. Kenneth E.de Graffenreid. "An Assessment of Inte:ligence (ioals and Tasks." working paper, transcript of the American Bar Association Standing Committee on Law and National Security Conference on Intelligence in a Post Cold War World. Washington, D.C., April-May 1992): 99.

27. Thomas F. Troy, "The 'Correct' Definition of Intelligence," International Journal of Intelligence and Counter Intelligence 5:4 (Winter 1991-92): 433, 450.

28. de Graffenreid 95.

29. Sherman Kent, Strategic Intelligence for American World Policy (Princeton: Princeton University Press, 1949): vii.

30. Kent ix.

31. Abram Shulsky and Gary Schmitt, Understanding the World of Intelligence, 2nd ed. (Washington: Brassey's, 1993): 5.

32. Seaborn 3.

33. Walter Laqueur, A World of Secrets: The Uses and Limits of Intelligence (NewYork: Basic Books, 1985): 40.

34. Laqueur 38-54.

35. Jon Sigurdson and Patricia Nelson, "Intelligence Gathering and Japan: The Elusive Role of Grey Intelligence," International .ournal of Intelligence and ('ounter Intelligence 5, no.l (Spring 1991) 17-34.

36. Seaborn 4 .

37. Sigurdson and Nelson "Intrlligence Gathering and Japan" 22.

38. Sigurdson and Nelson "Intelligence Gathering and Japan" 22.

39. Sigurdson and Nelson "Intelligence Gathering and Japan" 17.

40. Abram Shulsky and Jennifer Sims, What is Intelligence? Working Group on Intelligence Reform (Washington: Consortium for the Study of Intelligence, 1992): 30.

41. Interview, 1994.

42. Kent. Strategic Intelligence.

43. Kent viii.

Berkowitz and Goodman 3. 
Shulsky and Schmitt 189-197.

44. Jeffrey T. Richelson, The U.S. Intelligence Community (Cambridge: Ballinger, 1985): 2 .

45. Troy 433.

46. Laqueur $\mathbf{4 0 .}$

47. Kenneth E. de Graffenreid, Ernest R. May and Dr. Abram Shulsky, "An Assessment of Intelligence Goals and Tasks," working papers, American Bar Association Standing Committee on Law and National Security Conference on Intelligence in a Post Cold War World, Washington, D.C., April-May 1992, 86-157.

48. I have been influenced by the thinking of Dr. Abram Shulsky in relation to the proper role of intelligence in a liberal democratic nation-state.

49. Shulsky and Sims 25-26.

50. Seaborn 5 .

51. Seaborn 5 .

52. Christopher Andrew, "Intelligence in Context: Historical Background, Contemporary Context, and the Experience in Other Democratic Nations," working paper, American Bar Association Standing Committee on Law and National Security Conference on Intelligence in a Post Cold War World, Washington, D.C., April-May 1992, 38.

53. Pierre Marion, "L'Ancien Chef Des Services Secrets Se Met A Table" Jeune Afrique 12 (May-June 1991): 50.

54. Shulsky. What is Intelligence? 30.

55. Adda B. Bozeman, Strategic Intelligence \& Statecraft (New York: Brassey's, 1992): 9-10.

56. Bozeman 2.

57. Shulsky. Silent Warfare 1-3.

58. Security Intelligence Review Committee: Annual Report 1988-89 (Ottawa: Minister of Supply and Services, 1989): 71-72. On Course: National Security for the 1990s (Ottawa: Solicitor General Canada, February 1991): 51. People and Process in Transition: Report to the Solicitor General by the Independent Advisory Team on the Canadian Security Intelligence Service (Ottawa: Solicitor General Canada, October 
1987): 18.

59. T. D'Arcy Finn, "Does Canada Need A Foreign Intelligence Service'?" Canadian Foreign Policy 1.3 (Fall 1993): 149.

60. Nomination of Robert M. Gates, Hearings Before The Sclect Committec on Intelligence of the United States Senate. One Hundred Second Congress. First Session on Nomination of Robert M. Gates, To Be Director of Central Intelligence. Volume 1 (Washington: U.S. Government Printing Office, 1992).

61. Canada's Foreign Policy 13.

62. Canada's Foreign Policy 13.

63. Nomination of Robert M. Gates 2.

64. Security in a Changing World Report of the Special Joint Committec on Canada's Defence Policy (Ottawa: Canada Communication Group, 1994): 8.

65. Jessica Tuchman Matthews, "The Environment and International Security, World Security: Tends and Challenges at Century's End, eds, Michael T. Klare and Daniel C. Thomas).

66. Bozeman 2.

67. Shulsky. Silent Warfare 4.

68. Arnold Wolfers, " 'National Security' As An Ambiguous Symbol," Political Science Quarterly 67 (December 1952): 481.

69. David A. Baldwin and Helen V. Milner, "Economics and National Security," Power, Economics and Security ed. Henry Bienen (New York: Westview, 1992): 2950.

70. Baldwin and Milner 30-38. For the most part, 1 have either paraphrased or sythensized the thinking of Baldwin and Milner in this section. In addition, I have added examples to illustrate key points. This particular framework is very useful as an aide for thinking in terms of a risk management approach to public administration as a means for maximizing expenditures on national security programs in the national interest.

71. Stephen Breyer, Breaking the Vicious Circle: Toward Efffective Risk Regulation (Cambridge: Harvard University Press, 1993): 3. 
72. Charles J. Hitch, "National Security Policy as a Field of Economics Research," World Politics 12 (April 1960): 440.

73. As noted in the McDonald Commission Report, Canada's intelligence capacity pre-dates confederation. In 1864 a foreign intelligence capacity was established to gather information abroad on the threat of military attack posed by a group known as the Fenians located in the United States.

74. Alex Himelfarb, "Strategic Framework for Service Standards and Risk Management in Citizenship and Immigration Canada" (working paper, January 4, 1995): 7.

75. Solicitor General of Canada, the Hon. Bob Kaplan, Statement of the Government of Canada on the Publication of the Report of the Commission of Inquiry Concerning Certain Activities of the Royal Canadian Mounted Police, August 25, 1981.

76. Freedo and Security 407-411.

77. Delivered in a public speech by the Solicitor General in that year and contained in Ministerial direction to the Director of the Canadian Security Intelligence Service dated September 26. 1989. The Ministerial direction was publicly released in 1992 pursuant to a request under the Access to Information Act.

78. Seaborn 3.

79. Frost and Gratton Spyworld 8.

80. Caleb Carr, "Aldrich Ames and the Conduct of American Intelligence," World Policy Journal 11 (Fall 1994): 20.

81. Christopher Andrew and Oleg Gordievsky, KGB: The Inside Story (New York: HarperCollins, 1990): 646.

82. Delicate Balance: $A$ Security Intelligence Service in a Democratic Society Report of the Special Committee of the Senate on the Canadian Security Intelligence Service (Ottawa: Minister of Supply and Services, 1983): 29.

83. Delicate Balance 29.

84. Canadian Security Intelligence Service Act, section 38, p.17.

85. CSIS Act, section 40, p.18.

86. CSIS Act, section 38, p.17. 
87. CSIS ACt, sub-section 33(1), p.15.

88. "The Role of the Inspector General of the Canadian Security Intelligence Service" (paper presented by then Inspector General of CSIS, Richard Thomsont. at the Canadian Association for Security and Intelligence Studies Annual conference. University of Victoria. May 1990): 1-10.

89. Delicate Balance 29.

90. Thomson "Role of the Inspector General" 6.

91. Thomson "Role of the Inspector General" 7.

92. CSIS Act, section 38. p.17.

93. Delicate Balance 29.

94. Thomson "Role of the Inspector General" 8.

95. Privy Council Office, 1994-95 Main Estimates, Part III Expenditure Plan (Ottawa: Minister of Supply and Services, 1994): 11.

96. Public statement by Prime Minister Chretien.

97. People and Process 28. On Course 9. SIRC Annual Report 1987-88 7. Ministerial Direction to CSIS outlining the regime for the Director's accountability to the Minister dated June 22, 1989 and released in 1992 pursuant to a request under the Access to Information Act.

98. On Course 7.

99. Ministerial Direction to CSIS on Director's accountability to the Minister, June 22, 1989.

100. On Course 8.

101. On Course 8.

102. By convention, these are written guidelines of a continuing nature provided by the Solicitor General to the Director of CSIS. In theory, actual drafting of these guidelines, formally known as 'Ministerial directions' not 'directives', is carried out in a collaborative manner by officials representing the Solicitor General Secretariat, CSIS and other interested departments or agencies, respectively.

103. On Course 7-16. 
104. SIRC Annual Reports (1993-94): 35-6 \& (1992-93): 38-9.

105. Annual Statement on National Security, the Hon. Herb Gray, P.C., M.P., Solicitor General of Canada, House of Commons, April 11, 1994: 3 and by the Honourable Doug Lewis, P.C., Q.C., M.P., April 1, $1993 .$.

106. Annual Statement on National Security 1994: 1.

107. CSSS Act 6.

108. SIRC Annual Report (1991-92): 73.

109. CSIS Act 2.

110. CSIS Act 7 .

111. Interview.

112. Familiarization: Customs Intelligence Revenue Canada, Customs and Excise, Intelligence Services Division (Ottawa: Revenue Canada, 1991): 1-17.

113. Foreign Affairs and International Trade Canada (FAITC), Main Estimates 1994-95. Purl III (Ottawa: Minister of Supply and Services, 1994): 18.

114. FAITC: 1994-95 Main Estimates 41-47.

115. FAITC: 1994-95 Main Estimates 23-27.

116. Farson "Accountable and Prepared?" 59. Samuel D. Porteous, "Economic Espionage: Issues Arising From Increased Government Involvement with the Private Sector" (CSIS Analyst, paper presented to the Canadian Association for Security and Intevigence Studies Conference, June 6, 1993).

117. FAITC Main Estimales 1994-95 24.

118. FAITC Main Estimates 1994-95 24.

119. FAITC Main Estimates 1994-95 24.

120. On Course 54.

121. On Course 54.

122. On C'ourse 54. 
123. David Pugliese, "Anti-terrorist squad operates in secrecy." The ('itizen June 2. 1933 A5.

124. In Flux 43.

125. Memorandum for Members of the Interdepartmental Committee on Security and Intelligence (ICSI) explaining the Privy Council Office Security and Intelligence Structures and Functions dated November 6, 1987 and released pursuant to a request under the Access to Information Act.

126. In Flux 43.

127. In Flux 45.

128. In Flux 45.

129. Interview.

130. The Budget Plan, The Honourable Paul Martin, P.C., M.P.. Minister of Finance (Ottawa: Department of Finance, February 1994): 28.

131. Farson. "Accountable and Prepared?" 65.

132. Intelligence Newsletter (Paris: April 25, 1990): 4.

133. Heritage Front Affair 2-7. Frost Spyworld 21, 35 and 261.

134. Alvin and Heidi Toffler, War and Anti-War: Survival at the Dawn of the 2/st Century (Boston: Little, Brcinn, 1993): 154, 160.

13). Bozeman 24 .

136. Securi:', in a Changing World 8.

137. Memorandum from Department of Public Security, Deputy Minister V. Peter Harder to all staff of the Department of Public Security Canada entitled "Continuing Reflections on Public Security Canada" dated October 8, 1993.

138. Freedom and Security 643.

139. Richard H. Ullman, "Redefining Security," International Security 8 (Summer 1983): 129-153.

140. Bozeman 25. 
141. Ministerial direction to CSIS regarding CSIS' use of human sources dated October 30, 1989 and Ministerial direction to CSIS regarding the general principles and policies governing the conduct of CSIS investigations dated October 30, 1989. Both directions were released in 1992 pursuant to a request under the Access to Information Act.

142. Loch K. Johnson, "Smart Intelligence," Foreign Policy 89 (Winter 1992-93): 69.

143. Security Intelligence Review Committee Annual Reports (1990-91): 31; (199192): 41; and (1992-93): 45.

144. SIRC Annual Report (1993-94) 2.

145. Delicate Balance 9.

146. C.E.S. Franks, "Accountability of the Canadian Security Intelligence Service" (paper prepared for Canadian Association for Security and Intelligence Studies Annual Conference, August 1987): 1.

147. Franks "Accountability" 2.

148. Solicitor General of Canada, the Honourable Bob Kaplan, Statement of the Government of Canada on the Publication of the Report of the Commission of Inquiry Concerning Certain Activities of the Royal Canadian Mounted Police, August 25, 1981.

149. Freedom and Security 43.

150. C.E.S. Franks, Parliament and Security Matters, A Study prepared for the Commission of Inquiry Concerning Certain Activities of the Royal Canadian Mounted Police (Ottawa; Minister of Supply and Services, 1979): 1.

151. Franks Parliament 2-3. Franks, "Accountability" 3.

152. Stuart Farson, "Parliament's Capacity to Conduct a Comprehensive Review: Weak Link in the Chain of Accountability?"(paper pres nted for the Security Intelligence Review Committee's Vancouver Seminar, February 1991): 7; Franks "Accountability" 23; and In Flux Recommendations 87, 88, 107, 108 and 117.

153. A. Stuart Farson, "Countering the Security threat in the 1980s; McDonald's Legacy and the Need for Effective and Efficient Control" (paper Prepared for the Security Intelligence Review Committee's Research Seminar "Canadian Security Intelligence in the 80's, Meach Lake, Ottawa, October 1985): 21. 
154. In Flux (Recommendation 117): 201-2.

155. Intelligence Reorganization Act of 1992, A Bill to amend the National Security Act of 1947 to reorganize the United States Intelligence Community to provide for the improved management and execution of United States intelligence activities, and for other purposes, 102d Congress, 2D Session. (Washington, D.C.. February 5, 1992): 5.

156. British Intelligence Services Act 1994 (London: Her Majesty's Stationery Office and Queen's Printer of Acts of Parliament, May 1994): 1.

157. Intelligence Services Act.

158. Intelligence Services Act.

159. Intelligence Services Act.

160. Intelligence Services Act.

161. On Course 14. Ministerial direction on conduct of investigations (October 1989): 4. Ministerial direction on use of human sources (October 1989): 3-4.

162. Section 54 Report to the Solicitor General of Canada on CSIS' Use of its Investigative Powers with Respect to the Labour Movement Report prepared by the Security Intelligence Review Committee for the Solicitor General of Canada under Section 54 CSIS Act (Ottawa: March 25, 1988): 5.

163. Heritage Front Affair 2-6.

164. Heritage Front Affair Chapter XIII.

165. Franks, "Accountability" 10.

166. Freedom and Security 426.

167. Freedom and Security 426.

168. Minutes of Proceedings and Evidence of the Sub-Committee on National Security, House of Commons, Issue No,2, Thursday, November 28, 1991, p.6.

169. CSIS Explanatory Notes part of legislative proposals package entitled "Effective Security in a Democratic Society" released by Solicitor General of Canada (Ottawa: 1983): 16.

170. CSIS Act 28-9. Security Offenses Act 2. 
171. Farson "Parliament's Capacity" 8-9.

172. Farson "Parliament's Capacity" 9-10.

173. On Course Foreword by Solicitor General of Canada Pierre H. Cadieux.

174. Sub-Committee of the Standing Committee on Justice and the Solicitor General on National Security, Mission Statement and Worlplan of the National Security SubCommittee, News Release (Ottawa: September 25, 1991): 1-2.

175. Annual Statement on National Security by the Solicitor General of Canada, the Honourable Doug Lewis, P.C., Q.C., M.P., House of Commons, April 1, 1993 and by the Honourable Herb Gray, P.C., M.P., House of Commons, April 11, 1994.

176. Canadian Security Intelligence Service Public Report (Ottawa: Minister of Supply and Services, 1993 and 1994).

177. Minister of Justice and Attorney General of Canada Federal Judicial Appointments Process April 1994: 1.

178. Federal Judicial Appointments Process.

179. United States Presidential National Security Directive (NSD) No.29, Fact Sheet on Intelligence Capabilities: 1992-2005 (Was'ington: United States Government, November 15, 1991): 2.

180. Arthur Hulnick, "Business Intelligence Lessons Learned from the CIA" (Department of International Relations, Boston University, paper prepared for the annual meeting of the International Studies Association, Washington, D.C., March 29, 1994): 4.

181. May "Assessment of Intelligence Goals and Tasks" 152.

182. Farson "Accountable and Prepared?" 52.

183. On Course 57.

184. Delicale Balance (emphasis added) 19.

185. Frost and Gratton Spyworld 193.

186. Frost and Gratton Spyworld 93.

187. On Course 51.

188. On Course 57. 
189. James J. Wirtz. "Constraints on Intelligence Collaboration: The Domestic Dimension." International Journal of Intelligence and counter Intelligence 6:1 (Spring 1990): 90.

190. T. D'Arcy Finn, "Does Canada Need A Foreign Intelligence Service?". Canadian Foreign Policy 1:3 (Fall 1993): 160.

191. Henry Mintzberg. The Rise and Fall of Strategic Plunning: Reconceiving Roles. for Planning, Plans, Planners (New York: Free Press, 1994): 414-6.

192. Treasury Board Secretariat Drafi Guidelines for Government Expenditure Management, 1994.

193. Robert Land, "Partnership Strategy and Partnerships Workplan" (Working paper prepared for the department of Citizenship and Immigration, December 1994: 4).

194. Ward P.D. Elcock, Deputy Clerk, Security and Intelligence Secre -riat, Privy Council Office, Minutes of Proceedings and Evidence of the Sub-Committec on National Security, Issue No. 11 (Tuesday, June 15, 1993): 5.

195. SIRC Annual Report 1993-94 statement attributed to the Inspector General of CSIS, Ms. Ursula Menke, 54.

196. SIRC Annual Report 1993-94 statement attributed to then Inspector General of CSIS, Ms. Ursual Menke, p.54.

197. SIRC Annual Report 1993-94 19-21.

198. Security in a Changing World 9.

199. Wirtz "Constraints" 86.

200. H. Bradford Westerfield, "America and the World of Intelligence Liaison" (Yale University, paper presented at the Canadian Association for Security and Inteiligence Studies, Ottawa, March 1994): 14. CSIS Public Annual Reports 1991, 1992, 1993. Security Intelligence Annual Reports 1985-1994.

201. CSIS Annual Report 19937.

202. By foreign intelligence service, this thesis refers to an agency which deploys officers as opposed to satellites to collect abroad, by covert and overt means, intelligence on security, economic, political and military matters related to other nation-states in Canada's national interests. 
203. Arthur S. Hulnick, "Intelligence Cooperation in the Post-Cold War Era: A New Game Plan?" International Journal of Intelligence and Counterintelligence 5:4 (Winter 1991-92): 455.

204. Freedom and Security 642.

205. SIRC Annual Report. 1993-9423.

206. Farson "Accountable and Prepared?" 57.

207. Westerfield "America and the World of Intelligence Liaison" 3.

208. Westerfield "America and the World of Intelligence Liaison" 7.

209. Westerfield "A. erica and the World of Intelligence Liaison" 15.

210. Westerfield "America and the World of Intelligence Liaison" 27.

211. Westerfield "America and the World of Intelligence Liaison" 27. Aharon Klieman, Statecraft in the Dark: Israel 's Practice of Quiet Diplomacy (Boulder,Co., 1988); especially chapter 5 .

212. Klieman Statecraft in the Dark.

213. Claire Hoy and Victor Ostrovsky, By Way of Deception (Toronto: Stoddart, 1990): 67-8. Minutes of Proceedings and Evidence of the Sub-Committee on National Security, Issue No.3, February 19 and 26, 1992, Witness Victor Ostrovsky, p.39.

214. Westerfield "America and the World of Intelligence Liaison" 29-30.

215. Andrew and Gordievsky KGB: The Inside Story 4,8. Gordon Prook-Shepherd, The Storm Birds: Soviel Post-War Defectors (, 1988): 271.

216. Codevilla Informing Statecrafi 78.

217. Westerfield "America and the World of Intelligence Liaison" 30-31.

218. Westerfield "America and the World of Intelligence Liaison" 39-40.

219. Bozeman Strategic Intelligence 5.

220. Westerfield "America and the World of Intelligence Liaison" 42-43.

221. Frost and Gratton Spyworld 19.

222. Frost and Gratton Spyworld 193. 
223. Frost and Gratton Spyworld 194.

224. Seymour M. Hersh. The Samson Oplion: Israd's Nuclear Arsenal and American Foreign Policy (New York. 1991). Bill Keller. "South Africa Says It Built 6 Atom Bombs," New York Times (25 March 1993), Section A. pp. 1.12. Michacl R. Gordon, "Washington Welcomes de Klerk Disclosure. But Wants More Details." New" York Times (25 March 1993), Section A. p.12.

225. Westerfield "America and the World of Intelligence Liaison" 45-7.

226. Frost and Gratton Spyworld.

227. Frost and Gratton Spyworld 7.

228. Westerfield "America and the World of Intelligence Liaison" 45-7.

229. Gideon Doron, "The Vagaries of Intelligence Sharing: The Political Imbalance" International Journal of Intelligence and counter Intelligence 6:2 (Summer 1993): 139.

230. Doron "The Vagaries of Intelligence Sharing" 139.

231. John Starnes, "A Canadian Secret Intelligence Service?" International Perspectives (July/August 1987): 7.

232. On Course 57.

233. In Flux 37.

234. Finn 149.

235. Peter H. Russell, "Should Canada Establish A Foreign Intelligence Agency?" (paper written for the Security Intelligence Review Committee, December 1989): 3.

236. Finn "Does Canada Need A Foreign Intelligence Service?" 159.

237. Starnes "A Canadian Secret Intelligence Service?" 8.

238. Pierre Marion, "Interview L'Ancien Chef Des Services Secrets" 40-55.

239. Canada's Foreign Policy: Principles and Priorities for the Furure, Report of the Special Joint Committee Reviewing Canadian Foreign Policy (Ottawa; Minister of Supply and Services, 1994): 9.

240. Canada's Foreign Policy: Principles and Prioritics 11. 
241. Laqueur World Of Secrets.

242. Laqueur World of Secrets.

243. Hinsley, British Intelligence During World War II, Vols $I$ and 3.

244. Shulsky Silent Warfare.

245. Shulsky Silent Warfare.

246. Shulsky Silent Warfare.

247. Shulsky Silent Warfare.

248. Stansfield Turner, "Intelligence for a New World Order" Foreign Affairs 70:4 (Fall 1991): 152.

249. Stanley Kober, "The CIA As Economic Spy: The Misuse of U.S. Intelligence After the Cold War" Policy Analysis 185 (December 8, 1992): 3.

250. Quote from Professor Denis Stairs, Dalhousie University, Canada's Foreign Policy: Principles and Priorities for the Future 12.

251. Hulnick 4.

252. Peter Schweizer, Friendly Spies: How America's Allies Are Using Economic Espionage To Steal Our Secrets (New York: Atlantic Monthly Press, 1993): 36 and chapters 4 and 5.

253. Heritage Front Affair.

254. On Course 49.

255. On Course 49.

256. On Course 49.

257. Privy Council Office, "Foreign Intelligence For Canada" (Ottawa, Privy Council Office Staff Report 1984).

258. Farson "Accountable and Prepared?"

259. Farson "Accountable and Prepared?"

260. Farson "Accountable and Prepared" 56.

261. Farson "Accountable and Prepared?" 57. 
262. Bruce D. Berkowitz and Allan E. Goodman. "Why Spy - and How - in the 1990s" Orbis 36:2 (Spring 1992): 278-80.

263. Robert M. Gates, "The CIA and American Foreign Policy" Foreign Afficirs (Winter 1987-88): 219. Yehoshafat Harkabi. "The Intelligence-Policymaker Tangle" The Jerusalem Quarterly (Winter 1984): 125-131.

264. In late 1994, the Department of Citizenship and Immigration created a similar position.

265. Gates "CIA and American Foreign Policy" 219.

266. Berkowitz and Goodman "Why Spy - and How - in the 1990s" 277.

267. James Adams, The New Spies

268. Interview 1994.

269. Caleb Carr, "Aldrich Ames and the Conduct of American Intelligence," World Policy Journal (Fall 1994).

270. Frost and Gratton Spyworld. Richard Cleroux. Official Secrets: The Siory Behind the Canadian Security Intelligence Service (Toronto: McGraw-Hill Ryerson, 1990).

271. SIRC Annual Report 1991-925.

272. Caleb Carr "Aldrich Ames and the Conduct of American Intelligence." 


\section{BIBLIOGRAPHY}

Adams, James. The New Spies: Exploring the Frontiers of Espionage. London: Random House, 1994.

Andrew, Christopher. "Intelligence in Context: Historical Background, Contemporary Context, and the Experience in Other Democratic Nations." Working paper, American Bar Association Standing Committee on Law and National Security Conference on Intelligence in a Post Cold War World, Washington, D.C., April-May 1992.

Andrew, Christopher, and Oleg Gordievsky. KGB: The Inside Story of its Foreign Operations from Lenin to Gorbachev. New York: HarperCollins, 1990.

Andriamirado, Sennen, Hamid Barrada, et Hugo Sada. "L'Ancien chef des services secrets se met a table." Jeune Afrique 12 Mai-Juin 1991: 40-55.

Baldwin, David A., and Helen V. Milner. "Economics and National Security." Chapter 3 in Power, Economics and Security: The United States and Japan in Focus, edited by Henry Bienen, 29-50. New York: Westview, 1992.

Berkowitz, Bruce. D., and Allan E. Goodman. Strategic Intelligence for American National Security. Princeton: Princeton University Press, 1989.

. "Policy Brief: Why Spy - and How - in the 1990s." Orbis 36, no.2 (Spring 1992): 269-80.

Beschloss, Michael, and Strobe Talbott. At the Highest levels: The Inside Story of the End of the Cold War. Boston: Little, Brown and Company, 1993.

Blais, Jean Jacques. "The Political Accountability of Intelligence Agencies Canada." Intelligence and National Security 4, no.1 (January 1989): 108-18.

Boren, David L. "The Intelligence Community: How Crucial?" Foreign Affairs 71, no.3 (Summer 1992): 52-62.

Bozeman. Adda B. Strategic Intelligence \& Statecraft. New York: Brassey's, 1992.

Brook-Shepherd. The Storm Birds: Soviet Post-War Defectors. London: George Weidenfeld and Nicolson, 1988. 
Bryden, John. Best Kept Secret: Canadian Secret Intelligence in the Second World War. Toronto: Lester, 1993.

Bryer, Stehpen. Breaking the Vicious Circle: Toward Effective Risk Regulation. Cambridge: Harvard University Press, 1993.

Canada. In Flux But Not In Crisis. Report of the House of Commons Special Committee on the Review of the CSIS Act and the Security Offences Act. Ottawa: Government Publishing Center, September 1990.

. Security in a Changing World. Report of the Special Joint Committee un Canada's Defence Policy. Ottawa: Canada Communication Group, 1994.

- Delicate Balance: A Security Intelligence Service in a Democratic Society. Report of the Special Committee of the Senate on the Canadian Security Intelligence Service. Ottawa: Minister of Supply and Services, 1983.

Canada's Foreign Policy: Principles and Priorities for the Future, Report of the Special Joint Committee Reviewing Canadian Foreign Policy (Ottawa; Minister of Supply and Services, 1994): 9.

Canadian Security Intelligence Service Act. 1984.

Canadian Security Intelligence Service. Canadian Security Intelligence Service Public Report. Ottawa: Minister of Supply and Services, 1991, 1992, 1993 and 1994.

Carr, Caleb. "Aldrich Ames and the Conduct of American Intelligence. "World Policy Journal 11 (Fall 1994): 19-28.

Carver Jr., George A. "Intelligence in the Age of Glasnost." Foreign Affairs 69, no. 3 (Summer 1990): 147-166.

Cleroux, Richard. Official Secrets: The Story Behind the Canadian Security Intelligence Service. Scarborough: McGraw-Hill Ryerson, 1990.

$5-9$. . "L'affaire Morin." The Canadian Forum 1021, no. 810 (June 1992):

Codevilla, Angelo. Informing Statecraft: Intelligence for a New C'entury. New York: Free Press, 1992. 
Díley, Brian D., and Patrick J. Parker, eds. Soviet Strategic Deception. Lexington: D.C. Heath, 1987.

Dalby, Simon. "Security, Intelligence, the National Interest and the Global Environment." Paper presented at a conference organized by the Canadian Association for Security and Intelligence Studies on Intelligence Analysis and Assessment: The Producer/Policy Maker Relationship in a Changing World, Ottawa, On., October 1994.

de Graffenreid, Kenneth E. "An Assessment of Intelligence Goals and Tasks." Working paper, American Bar Association Standing Committee on Law and National Security Conference on Intelligence in a Post Cold War World, Washington, D.C., April-May 1992.

Doron, Gideon. "The Vagaries of Intelligence Sharing: The Political Imbalance." International Journal of Intelligence and Counter Intelligence 6, no.2 (Summer 1993): 135-146.

Esposito, John L. The Islamic Threat: Myth or Reality? New York: Oxford University Press, 1992.

Familiarization: Customs Intelligence Revenue Canada, Customs and Excise, Intelligence Services Division (Ottawa: Revenue Canada, 1991): 1-17.

Farson, Stuart. "Countering the Security Threat in the 1980s: McDonald's Legacy and the Need for Effective and Efficient Control." Working paper prepared for the Security Intelligence Review Committee's Research Seminar on Canadian Security Intelligence in the 80's, Meach Lake, On., October 1985.

- "Parliament's Capacity to Conduct a Comprehensive Review: Weak Link in the Chain of Accountability?" Working paper presented for the Security Intelligence Review Committee's Vancouver Seminar, February 1991.

- "Intelligence for a Principled Power: Canada's Security and Intelligence Community in the Post Cold War Era." A paper prepared under contract for Centre International de Criminologie Comparee, University of Montreal, November 1991.

- "Accountable and Prepared? Reorganizing Canada's Intelligence Community for the 21st Century" Canadian Foreign Policy 1, no.3 (Fall 1993): 43-66.

Finn, Ted, D'Arcy. "Does Canada Need A Foreign Intelligence Service?" Canadian Foreign Policy 1, no. 3 (Fall 1993): 149-162. 
Fort, Randall M. Economic Espionage: Problems and Prospects. Washington: Consortium for the Study of Intelligence, 1993.

Franks, C.E.S. Parliament and Security Matters. A Study prepared for the Commission of Inquiry Concerning Certain Activities of the Royal Canadian Mounted Police. Ottawa: Minister of Supply and Services. 1979.

. "Accountability of the Canadian Security Intelligence Service." Working paper prepared for the Canadian Association for Security and Intelligence Studies Annual Conference, August 1987.

Freedom and Security Under the Law, Commission of Inquiry Concerning Certain Activities of the Royal Canadian Mounted Police, Second Report - Volune 1 (Ottawa: Minister of Supply and Services, 1991): 645.

Frost, Mike, and Michel Gratton. Spyworld: Inside the Canadian and Americun Intelligence Establishments. Toronto: Doubleday, 1994.

Gates, Robert M. "The CIA and American Foreign Policy." Foreign Affuirs (Winter 1987-88): 215-230.

Harkabi, Yehoshafat. "The Intelligence-Policymaker Tangle." The Jerusalem Quarlerly (Winter 1984): 125-131.

Harris, David. "Attack of the Industrial Spies." Globe and Mail. March 29, 1993.

Hersh, Seymour M. The Samson Option: Israel's Nuclear Arsenal and American Foreign Policy. New York, 1991.

Hitch, Charles J. "National Security Policy as a Field of Economics Research." World Politics 12 (April 1960).

House of Commons, Special Committee on The Review of the CSIS Act and the Security Offences Act, Minutes of Proceedings and Evidence, no. 6, December 5, 1989.

- Special Committee on The Review of the CSIS Act and the Security Offences Act, Minutes of Proceedings and Evidence, no. 10, January 17,18, 1990.

- Sub-Committee on National Security of the Standing Committee on Justice and the Solicitor General, Minules of Proceedings and Evidence, no. 1, June 18, 1991, September 17,23, 1991, and November 6,19, 1991. 
- Sub-Committee on National Security of the Standing Committee on Justice and the Solicitor Cieneral, Minutes of Proceedings and Evidence, no. 2, November 28, 1991.

. Sub-Committee on National Security of the Standing Committee on Justice and the Solicitor General, Minutes of Proceedings and Evidence, no. 3, February 19,26, 1992.

- Sub-Committee on National Security of the Standing Committee on Justice and the Solicitor General, Minutes of Proceedings and Evidence, no. 11, June 15, 1993.

. Sub-Committee on National Security of the Standing Committee on Justice and the Solicitor General, Minutes of Proceedings and Evidence, no. 1, June 7,21, 1994, and September 12,13, 1994.

. Sub-Committee on National Security of the Standing Committee G.1 Justice and the Solicitor General, Minutes of Proceedings and Evidence, no. 2, October 6,17,18, 1994.

. Sub-Committee of the Standing Committee on Justice and the Solicitor General on National Security. Mission Statement and Worlplan of the National Security Sub-Cummittee, News Release. Ottawa: September 25, 1991.

- Ward P.D. Elcock, Deputy Clerk, Security and Intelligence Secretariat, Privy Council Office, Minutes of Proceedings and Evidence of the Sub-Committee on National Security, Issue No. 11, Tuesday, June 15, 1993.

Hoy, Claire, and Victor Ostrovsky. By Way of Deception: A Devastating Insider's Portrail of the MOSSAD. Toronto: Stoddart, 1990.

Hulnick, Arthur S. "Business Intelligence Lessons Learned from the ClA." Paper prepared for the annual meeting of the International Studies Association, Washington, D.C., March 29, 1994.

Improving Social Security in Canada: A Discussion Paper. Ottawa: Human Resources Development Canada, 1994: 7-11.

Jardine. James $\mathrm{W}$. The Use of Security Intelligence in Canadian Criminal Proceedings. Speaking notes for a seminar. Ottawa, On., October 3, 1991.

Johnson, Loch K. "Smart Intelligence," Foreign Policy 89 (Winter 1992-93): 53-69. 
Kent, Sherman. Strategic Intelligence for American World Policy. Princeton: Princeton University Press, 1949.

Klare, Michael T and Daniel C. Thomas, eds. World Security: Trends and Challenges at Century's End. St. Martin's Press: New York, 1991.

Kober, Stanley. "The CIA As Economic Spy: The Misuse of U.S. Intelligence After the Cold War." Policy Analysis no. 185 (December 1992): 1-21.

Laqueur, Walter. A World of Secrets: The Uses and Limits of Intelligence. New York: Basic Books, 1985.

Mintzberg, Henry. The Rise and Fall of Strategic Planning: Reconceiving Roles for Planning, Plans, Planners. New York: Free Press, 1994.

Office of the Inspector General of the Canadian Security Intelligence Service. "The Role of the Inspector General of the Canadian Security Intelligence Service" (paper presented by then Inspector General of CSIS, Richard Thomson, at the Canadian Association for Security and Intelligence Studies Annual Conference, University of Victoria, May 1990): 1-10.

Porteous, Samuel D. "Economic Espionage: Issues Arising From Increased Government Involvement with the Private Sector." CSIS Analyst, paper presented to the Canadian Association for Security and Inteiligence Studies Conference, June 6, 1993.

Privy Council Office. Privy Council Office 1994-95 Estimates, Part III Expenditure Plan. Ottawa: Minister of Supply and Services Canada, 1994.

- Memorandum for Members of the Interdepartmental Committee on Security and Intelligence (ICSI) explaining the Privy Council Office Security and Intelligence Structures and Functions. November 6, 1987 and released pursuant to a request under the Access to Information Act.

Public Security Canada. Memorandum from Department of Public Security, Deputy Minister V. Peter Harder to all staff of the Department of Public Security Canada entitled "Continuing Reflections on Public Security Canada," October 8, 1993.

Pugliese, David "Anti-terrorist squad operates in secrecy," The Citizen June 2, 1993 A5.

Richardson, Boyce. Time to Change: Canada's Place in a World in Crisis. Toronto: Canadian Institute for Peace and Security, Summerhill Press, 1990. 
Richelson, Jeffrey T. The U.S. Intelligence Community. Cambridge: Ballinger, 1985.

Russell, Peter H. Should Canada Establish A Foreign Intelligence Agency? Paper written for the Security Intelligence iseview Committee, December 1989.

Seaborn, Blair. "Intelligence and Policy: What is Constant? What is Changing?" Commentary 45. Ottawa: Canadian Security Intelligence Service, June 1994.

Security Intelligence Review Committee. The Heritage Front Affair. Report to the Solicitor General, December 9, 1994.

Supply and Services.

. Annual Report 1984-1985 through 1993-1994. Ottawa: Minister of . Amending the CSIS Act: Proposals for the Special Committee of the House of Commons 1989. Ottawa: Minister of Supply and Services, 1989.

- Section 54 Report to the Solicitor General of Canada on CSIS' Use of its Investigative Powers with Respect to the Labour Movement. Ottawa: March 25, 1988.

Schweizer, Peter. Friendly Spies: How America's Allies are Using Economic Espionage to Steal Our Secrets. New York: Atlantic Monthly, 1993.

Shulsky, Abram and Gary Schmitt. Understanding the World of Intelligence, 2nd ed. Washington: Brassey's, 1993.

Shulsky, Abram and Jennifer Sims. What is Intelligence? Washington: Consortium for the Study of Intelligence, 1992.

Solicitor General Canada. On Course: National Security for the 1990s, The Government's Response to the Report of the House of Commons Special Committee on the Review of the Canadian Security Intelligence Service Act and the Security Offences Act. Ottawa: Minister of Supply and Services, February 1991.

- People and Process in Transition: Report to the Solicitor General by the Independent Advisory Team on the Canadian Security Intelligence Service. Ottawa: Solicitor General Canada, October 1987.

- Ministerial direction to CSIS regarding CSIS' use of human sources dated October 30, 1989 and Ministerial direction to CSIS reganding the general principles and policies governing the conduct of CSIS investigations dated October 30. 1989. Both directions were released in 1992 pursuant to a request under the Access to Information Act. 
- The Honourable Bob Kaplan, Statement of the Government of Canada on the Publication of the Report of the Commission of Inquiry Concerning Certain Activities of the Royal Canadian Mounted Police, August 25, 1981.

- CSIS Explanatory Notes part of legislative proposals package entitled "Effective Security in a Democratic Society" released by Solicitor General of Canada. Ottawa: 1983.

- Annual Statement on National Security by the Solicitor General of Canada, the Honourable Doug Lewis, P.C., Q.C., M.P., House of Commons, April 1, 1993 and by the Honourable Herb Gray, P.C., M.P., House of Commons, April 11, 1994.

Stames, John. "A Canadian Secret Intelligence Service?" International Perspectives (July/August 1987).

Steven, Stewart. The Spy-Masters of Israel. New York: MacMillan, 1980.

The Budget Plan, The Honourable Paul Martin, P.C., M.P., Minister of Finance. Ottawa: Department of Finance, Februay 1994.

Toffler, Alvin and Heidi. War and Anti-War: Survival at the Dawn of the 2lst Century. Boston: Little, Brown, 1993.

Treasury Board Secretariat. Draft Guidelines for Government Expenditure Management, 1994.

Troy, Thomas F. "The 'Correct' Definition of Intelligence," International Journal of Intelligence and Counter Intelligence 5:4 (Winter 1991-92): 433-454.

U.K. Intelligence Services Act, 1994, c.13.

Ullman, Richard H. "Redefining Security," International Security 8 (Summer 1983): 129-153.

United States Presidential National Security Directive (NSD) No.29, Fact Sheet on Intelligence Capabilities: 1992-2005. Washington: United States Government, November 15, 1991.

U.S. House Permanent Select Committee on Intelligence. Report on Intelligence Authorization Act for Fiscal Year 1993, 102nd Cong., 2d sess., June 2, 1992. 
U.S. Senate. S.2198 To Amend the National Security Act of 1947 to Reorganize the United States Intelligence Community to Provide for the Improved Management and Execution of United States Intelligence Activities, and for Other Purposes, 102nd Cong., 2d sess., February 5, 1992.

U.S. Senate Select Committee on Intelligence. Nomination of Robert M. Gates, To Be Director Of Central Intelligence, Hearings on S. Hrg. 102-799, 102nd Cong., Ist sess., Vol.I, September 16, 17, 19, 20, 1991, Vol.II, September 24, October 1,2, 1991, and Vol.III, October 3,4,18, 1991.

. Review of Intelligence Organization, Hearing on S. Hrg. 102-91, 102nd Cong., 1st sess., March 21, 1991.

. S. 2726 To Amend the National Security Act of 1947 to improve U.S. Counter Intelligence Measures, Hearings S. Hrg. 101-1293, 101 st Cong., 2d sess., May 23 and July 12, 1990.

Westerfield, H. Bradford. "America and the World of Intelligence Liaison." Yale University, paper presented at the Canadian Association for Security and Intelligence Studies, Ottawa, March 1994.

Wirtz, James J. "Constraints on Intelligence Collaboration: The Domestic Dimension," International Journal of Intelligence and Counter Intelligence 6:1 (Spring 1990): 90.

Wolfers, Arnold. "'National Security' As An Ambiguous Symbol." Political Science Quarterly 67 (December 1952): 481-502. 

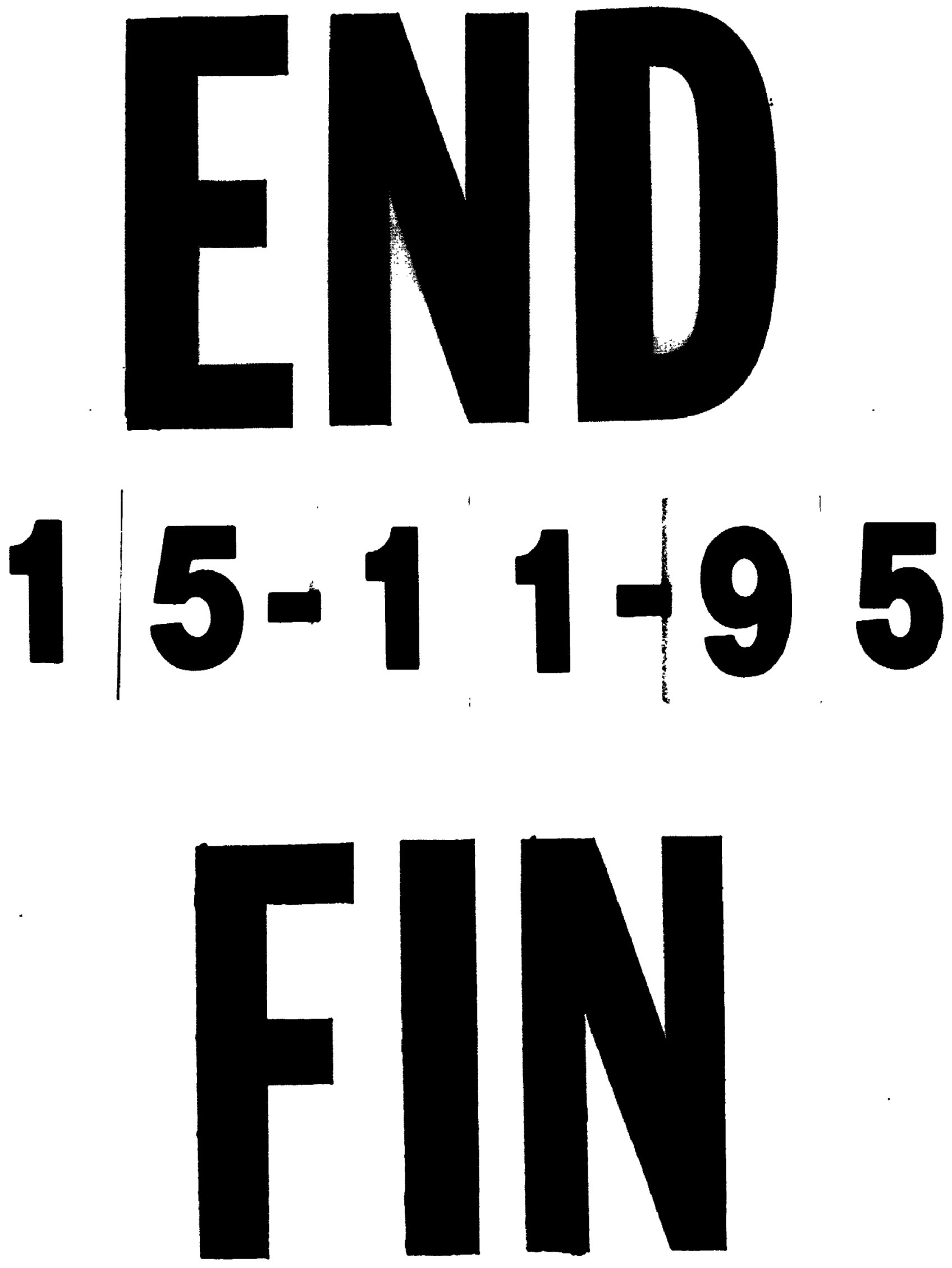